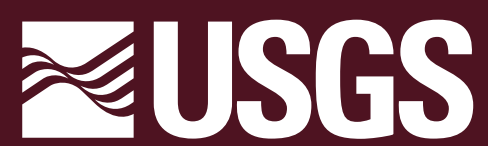

science for a changing world

Prepared in cooperation with the U.S. Army Corps of Engineers

\title{
Generalized Sediment Budgets of the Lower Missouri River, 1968-2014
}

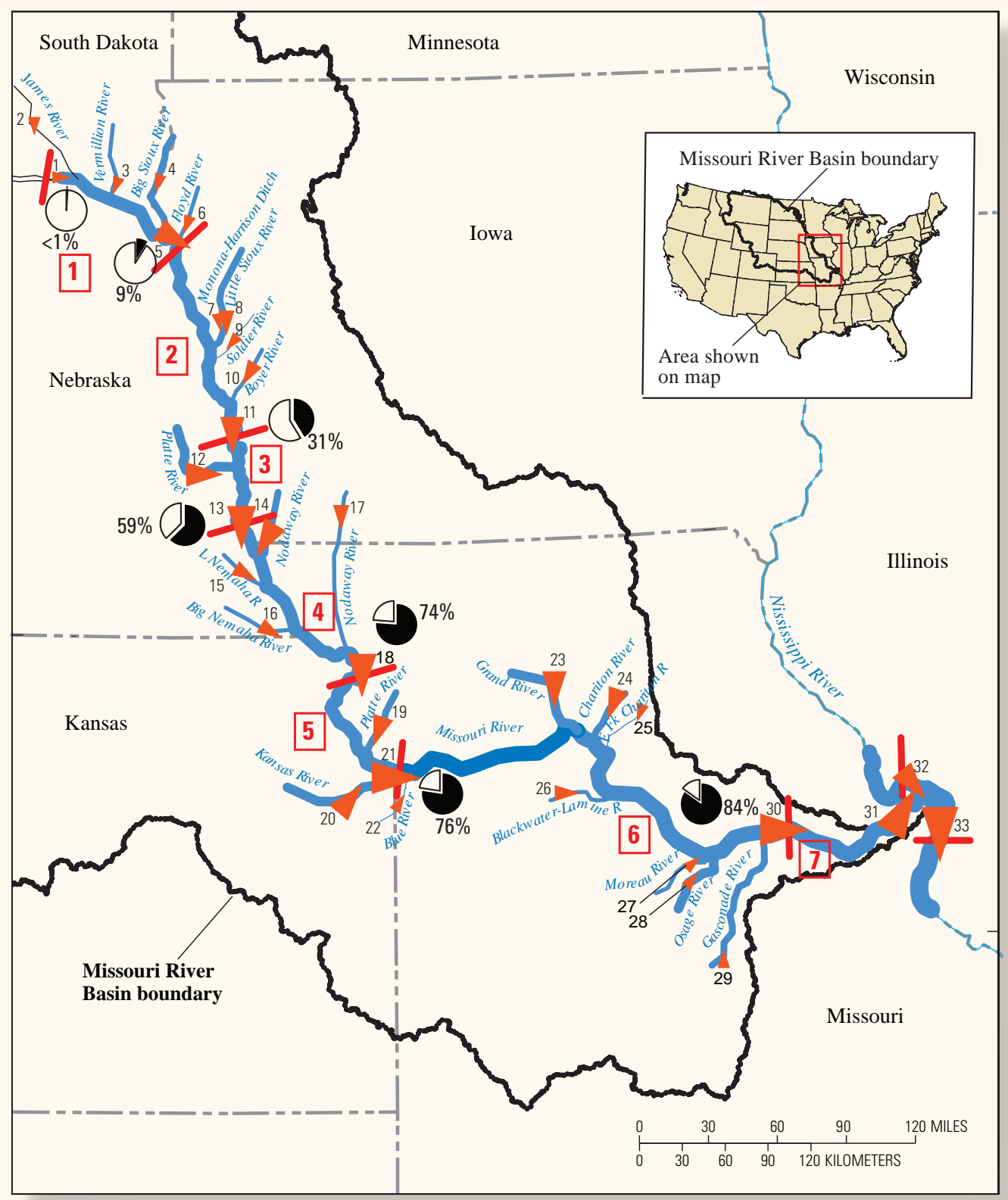

Scientific Investigations Report 2016-5097

U.S. Department of the Interior

U.S. Geological Survey 
Cover illustration: Modified version of figure 10 from this report. 


\section{Generalized Sediment Budgets of the Lower Missouri River, 1968-2014}

By David C. Heimann

Prepared in cooperation with the U.S. Army Corps of Engineers

Scientific Investigations Report 2016-5097 


\title{
U.S. Department of the Interior SALLY JEWELL, Secretary
}

\section{U.S. Geological Survey Suzette M. Kimball, Director}

\author{
U.S. Geological Survey, Reston, Virginia: 2016
}

For more information on the USGS - the Federal source for science about the Earth, its natural and living resources, natural hazards, and the environment—visit http://www.usgs.gov or call 1-888-ASK-USGS.

For an overview of USGS information products, including maps, imagery, and publications, visit http://www.usgs.gov/pubprod/.

Any use of trade, firm, or product names is for descriptive purposes only and does not imply endorsement by the U.S. Government.

Although this information product, for the most part, is in the public domain, it also may contain copyrighted materials as noted in the text. Permission to reproduce copyrighted items must be secured from the copyright owner.

Suggested citation:

Heimann, D.C., 2016, Generalized sediment budgets of the Lower Missouri River, 1968-2014: U.S. Geological Survey Scientific Investigations Report 2016-5097, 51 p., http://dx.doi.org/10.3133/sir20165097.

ISSN 2328-0328 (online) 


\section{Acknowledgments}

The author wishes to acknowledge funding and resources provided by the U.S. Army Corps of Engineers, Kansas City and Omaha Districts. Special acknowledgements are given to John Shelley, Kansas City District, and Dan Pridal, Omaha District, for their assistance with data requests and general information needs. 


\section{Contents}

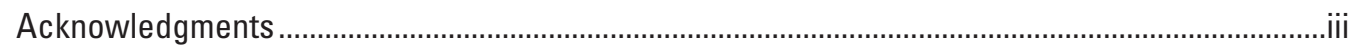

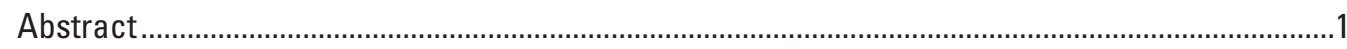

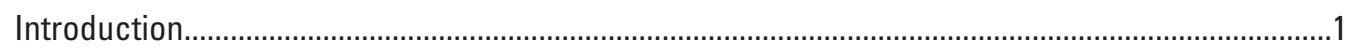

Sediment Sampling and Accounting in the Missouri River Basin ..........................................

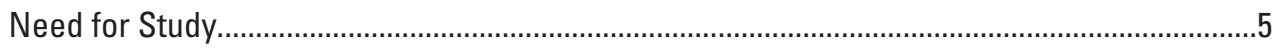

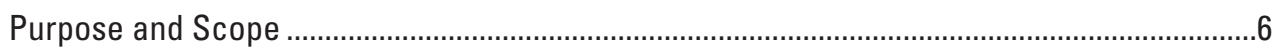

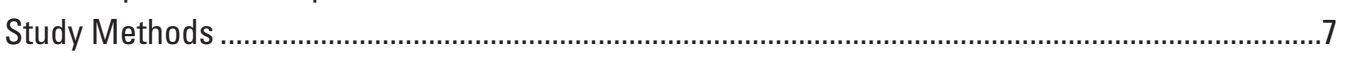

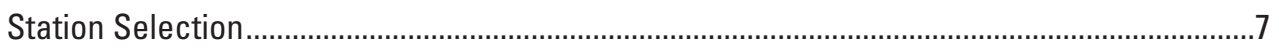

Sources of Sediment Data ........................................................................................................

Annual, Daily Suspended-Sediment Loads ....................................................................

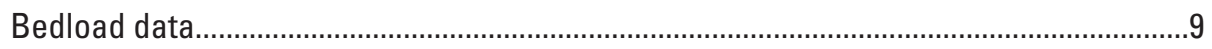

Miscellaneous Sediment Data .................................................................................9

Temporal Variations in Suspended-Sediment Loads and Concentrations..............................10

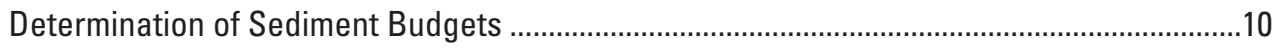

Average Annual Post-Impoundment Sediment Budget ....................................................11

Annual, Monthly, Daily Sediment Budgets .................................................................11

Sediment Budgets of the Lower Missouri River .........................................................................11

Temporal Changes in Suspended-Sediment Concentrations and Loads ................................11

Long-Term, 1968-2014 Sediment Budget .........................................................................18

Reach 1-Missouri River at Yankton, S. Dak., to Sioux City, lowa .................................23

Reach 2-Missouri River at Sioux City, lowa, to Omaha, Nebr. ...................................23

Reach 3-Missouri River at Omaha, Nebr., to Nebraska City, Nebr. ..............................23

Reach 4-Missouri River at Nebraska City, Nebr., to St. Joseph, Mo............................27

Reach 5-Missouri River at St. Joseph, Mo., to Kansas City, Mo..................................27

Reach 6-Missouri River at Kansas City, Mo., to Hermann, Mo...................................27

Reach 7-Missouri River at Hermann, Mo., to the Mississippi River at

St. Louis, Mo...................................................................................................

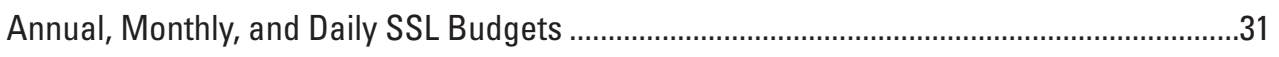

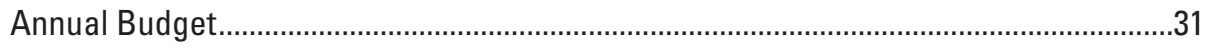

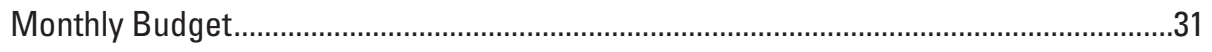

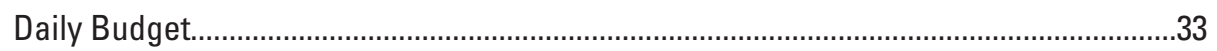

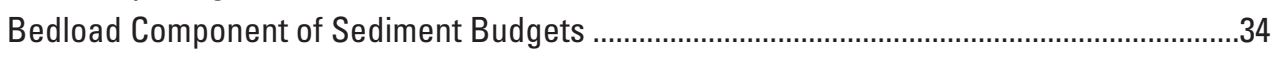

Sediment Data Gaps and Uncertainties .........................................................................

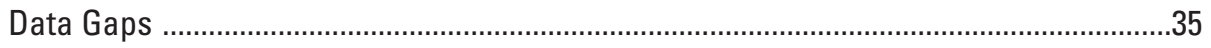

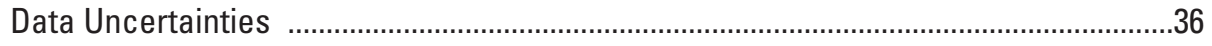

Suspended-Sediment Concentrations and Streamflow.................................................37

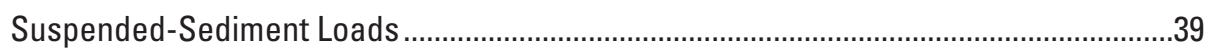

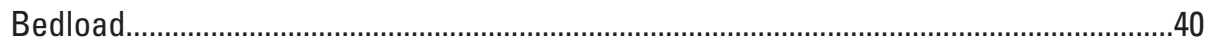

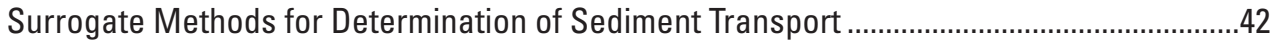

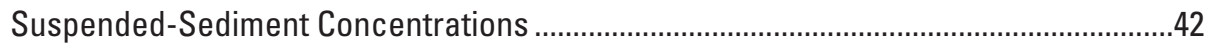

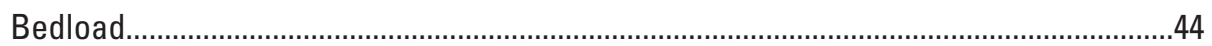

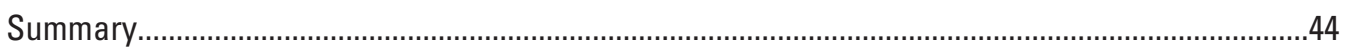

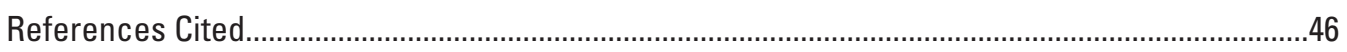

Tables 1-9 


\section{Figures}

1. Map showing Missouri River Basin and Lower Missouri River reach ................................2

2. Schematic showing components of sediment budget for a river reach .............................

3. Schematic showing categories of total sediment load....................................................

4. Schematic showing suspended-sediment budget of the Mississippi River Basin ..........5

5. Generalized framework for a Missouri River sediment budget........................................6

6. Map showing sediment monitoring stations used in sediment budget analyses and annual sediment load availability, Lower Missouri River Basin, 1968-2014 .............8

7. Graph showing temporal changes in flow-weighted suspended-sediment concentrations at selected stations in the Missouri and Mississippi River Basins, 1930-2014

8. Graphs showing temporal changes in suspended-sediment loads at selected stations in the Missouri and Mississippi River Basins, 1930-2014.

9. Graphs showing temporal changes in flow-adjusted suspended-sediment concentrations at main-stem Lower Missouri River stations, 1968-2014.

10. Map showing generalized suspended-sediment budget of the Lower Missouri River, 1968-2014

11. Map showing long-term average sediment budget, Lower Missouri River reach 1, Yankton, South Dakota, to Sioux City, lowa, 1968-2014.

12. Map showing long-term average sediment budget, Lower Missouri River reach 2, Sioux City, lowa, to Omaha, Nebraska, 1968-2014.

13. Map showing long-term average sediment budget, Lower Missouri River reach 3, Omaha, Nebraska, to Nebraska City, Nebraska, 1968-2014.

14. Map showingong-term average sediment budget, Lower Missouri River reach 4, Nebraska City, Nebraska, to St. Joseph, Missouri, 1968-2014.

15. Map showing long-term, average sediment budget, Lower Missouri River reach 5, St. Joseph, Missouri, to Kansas City, Missouri, 1968-2014

16. Map showing long-term, average sediment budget, Missouri River reach 6, Kansas City, Missouri, to Hermann, Missouri, 1968-2014

17. Map showing long-term average sediment budget, Lower Missouri River reach 7, Hermann, Missouri, to St. Louis, Missouri, 1968-2014 ...

18. Graph showing annual, monthly, and daily sediment budget for the Lower Missouri River, reach 3, Omaha, Nebraska, to Nebraska City, Nebraska, 1968-2014

19. Graph showing cumulative annual sediment budget residuals for Lower Missouri River reach 3, Omaha, Nebraska, to Nebraska City, Nebraska, 1968-2014.

20. Graph showing temporal trend in the stage of the Missouri River at Nebraska City, Nebraska, station for selected constant streamflows, 1930-2011.

21. Graph showing monthly suspended-sediment budget residuals for Lower Missouri River reach 3, Omaha, Nebraska, to Nebraska City, Nebraska, 1968-76.

22. Graph showing daily suspended-sediment budget residuals for Lower Missouri River reach 3, Omaha, Nebraska, to Nebraska City, Nebraska, 1968-76.

23. Graphs showing daily suspended-sediment budget residuals during selected floods for Lower Missouri River reach 3, Omaha, Nebraska, to Nebraska City, Nebraska, 1968-76.

24. Graph showing bedload and daily average streamflow for Lower Missouri River and Mississippi River main-stem stations, 1950-2014 . 
25. Schematic showing primary sources of uncertainty in the computation of suspended-sediment loads.

26. Graph showing inverse trends with time of the number of suspended-sediment concentration samples per year and the corresponding coefficient of variation of annual suspended-sediment load estimates, Missouri River at Hermann, Missouri, 1949-2009

\section{Tables}

Tables 1-9 are available for download as Excel files at http://dx.doi.org/10.3133/sir20165097.

1. Summary of sediment data availability and station characteristics of sediment monitoring stations used in study.

2. Annual suspended-sediment loads and flow-weighted concentrations for selected stations in the Lower Missouri and Mississippi River Basins, 1930-2014.

3. Daily suspended-sediment loads for selected stations in the Lower Missouri and Mississippi River Basins, 1939-2014.

4. Summary of bedload measurements and computations available for selected stations on the Lower Missouri and Mississippi Rivers, 1950-2014.

5. Missouri River commercial dredging mass by year and river reach, 1968-2014.

6. Estimated Missouri River Recovery Program sediment additions by year and by reach, 1993-2014.

7. Selected annual bed mass changes by reach, Lower Missouri River, 2007-14.

8. Long-term, average sediment budget for the Lower Missouri River, by reach, postimpoundment period, 1968-2014.

9. Annual, monthly, and daily sediment budget for the Lower Missouri River, reach 3, Omaha, Nebraska, to Nebraska City, Nebraska, 1968-2014. 


\section{Conversion Factors}

U.S. customary units to International System of U nits

\begin{tabular}{|c|c|c|}
\hline Multiply & By & To obtain \\
\hline \multicolumn{3}{|c|}{ Length } \\
\hline foot (ft) & 0.3048 & meter (m) \\
\hline mile (mi) & 1.609 & kilometer (km) \\
\hline \multicolumn{3}{|c|}{ Area } \\
\hline square mile $\left(\mathrm{mi}^{2}\right)$ & 2.590 & square kilometer $\left(\mathrm{km}^{2}\right)$ \\
\hline \multicolumn{3}{|c|}{ Volume } \\
\hline acre-foot (acre-ft) & 1,233 & cubic meter $\left(\mathrm{m}^{3}\right)$ \\
\hline \multicolumn{3}{|c|}{ Flow rate } \\
\hline cubic foot per second $\left(\mathrm{ft}^{3} / \mathrm{s}\right)$ & 0.02832 & cubic meter per second (m³/s) \\
\hline \multicolumn{3}{|c|}{ Mass } \\
\hline milligram (mg) & 0.001 & gram (g) \\
\hline ton, short $(2,000 \mathrm{lb})$ & 0.9072 & megagram (M g) \\
\hline ton per year (ton/yr) & 0.9072 & megagram per year ( $\mathrm{Mg}$ g/yr) \\
\hline ton per year (ton/yr) & 0.9072 & metric ton per year \\
\hline \multicolumn{3}{|c|}{ Density } \\
\hline pound per cubic foot (lb/ft³) & 16.02 & kilogram per cubic meter $\left(\mathrm{kg} / \mathrm{m}^{3}\right)$ \\
\hline pound per cubic foot (lb/ft³) & 0.01602 & gram per cubic centimeter $\left(\mathrm{g} / \mathrm{cm}^{3}\right)$ \\
\hline
\end{tabular}

Temperature in degrees Fahrenheit $\left({ }^{\circ} \mathrm{F}\right)$ may be converted to degrees Celsius $\left({ }^{\circ} \mathrm{C}\right)$ as follows:

${ }^{\circ} \mathrm{C}=\left({ }^{\circ} \mathrm{F}-32\right) / 1.8$.

\section{Datum}

Vertical coordinate information is referenced to the North American Vertical Datum of 1988 (NAVD 88) or the National Geodetic Vertical Datum of 1929 (NGVD29).

Horizontal coordinate information is referenced to the North American Datum of 1983 (NAD 83) or the North American Datum of 1927 (NAD27). 



\title{
Generalized Sediment Budgets of the Lower Missouri River, 1968-2014
}

\author{
By David C. Heimann
}

\section{Abstract}

Sediment budgets of the L ower M issouri River were developed in a study led by the U.S. Geological Survey in cooperation with the U.S. A rmy Corps of Engineers. The scope of the study included the devel opment of a long-term (post-impoundment, 1968-2014) average annual sediment budget and selected annual, monthly, and daily sediment budgets for a reach and period that adequate data were available. Included in the analyses were 31 main-stem and tributary stations of the Lower M issouri River and two M ississippi River stations- the M ississippi River below Grafton, Illinois, and the M ississippi River at St. Louis, M issouri.

L ong-term average annual suspended-sediment loads of $M$ issouri River main-stem stations ranged from 0.33 million tons at the M issouri River at Yankton, South Dakota, station to 71.2 million tons at M issouri River at Hermann, M 0., station. Gaged tributary gains accounted for 9-36 percent of the local reach budgets and cumulative gaged tributary contributions accounted for 84 percent of the long-term average suspendedsediment load of the M issouri River at Hermann, M o., station. Although the sediment budgets for seven defined main-stem reaches generally were incomplete- missing bedload, reach storage, and ungaged tributary contributions- the budget residuals (net result of sediment inputs and outputs) for six of the seven reaches ranged from -7.0 to 1.7 million tons, or from -9.2 to 4.0 percent of the reach output suspended-sediment load, and were within the 10 percent reported measurement error of annual suspended-sediment loads for large rivers. The remaining reach, downstream from Gavin's Point Dam, extended from Yankton, S. Dak., to Sioux City, I owa, and had a budget residual of -9.8 million tons, which was -88 percent of the suspended-sediment load at Sioux City.

The L ower M issouri River reach from O maha, N ebraska, to N ebraska City, N ebr., had periods of concurrent sediment data for each primary budget component with which to analyze and determine a suspended-sediment budget for selected annual, monthly, and daily time increments. The temporal changes in the cumulative annual budget residuals were poorly correlated with the comparatively steady 1968-2011 annual stage trends at the M issouri River at N ebraska City, N ebr., station. A $n$ accurate total sediment budget is devel oped by having concurrent data available for all primary suspended and bedload components for a reach of interest throughout a period.
Such a complete budget, with concurrent record for suspended-sediment load and bedload components, is unavailable for any reach and period in the Lower M issouri River. The primary data gaps are in bedload data, and al so in suspendedsediment gains and losses including ungaged tributary inputs and sediment storage. B edload data gaps in the M issouri River $B$ asin are much more prevalent than suspended-sediment data gaps, and the first step in the development of reach bedload budgets is the establishment of a standardized bedload monitoring program at main-stem stations.

The temporal changes in flow-adjusted suspendedsediment concentrations analyzed at main-stem M issouri River stations indicated an overall downward change in concentrations between 1968 and 2014. Temporary declines in flow-adjusted suspended-sediment concentrations during and following large floods were evident but generally returned to near pre-flood values within about 6 months.

Data uncertainties associated with the development of a sediment budget include uncertainties associated with the collection of suspended-sediment and bedload data and the computation of suspended-sediment loads. These uncertainties vary depending on the frequency of data collection, the variability of conditions being represented by the discrete samples, and the statistical approach to suspended-sediment load computations. The coefficients of variation of suspended-sediment loads of M issouri River tributary stations for 1968-2014 were greater, 75.0 percent, than the main-stem stations, 47.1 percent. The lower coefficient of variation at main-stem stations compared to tributaries, primarily is the result of the lower variability in streamflow and sediment discharge identified at main-stem stations. To obtain similar accuracy between suspended-sediment loads at main-stem and tributary stations, a longer period of record is required of the tributary stations. During 1968-2014, however, the M issouri River main-stem station record was much more complete (87 percent) than the tributary station record (28 percent).

\section{Introduction}

The Missouri River Basin (fig. 1) is the second largest river basin in the U nited States (the M ississippi River Basin is the largest) draining about one-sixth of the conterminous United States (529,350 square miles). The M issouri River is 
2,341 miles long from its headwaters in western M ontana to its mouth at St. L ouis, M issouri, making it the longest river in the United States. Bank stabilization and channel modifications to the M issouri River, associated with the M issouri River Bank Stabilization and Navigation Project (BSNP), started in 1912, and modifications began in earnest in the 1930s and continued through the 1980s (U.S. A rmy Corps of Engineers, 2009). Six major impoundments in the upper Missouri River Basin regulate the flow from 53 percent of the basin area upstream from St. Louis, M 0., following construction that began in 1933 and ended in 1966. These engineered modifications, which include tributary impoundments, and land-use changes, which include changes in agricultural practices, have greatly altered streamflows and, to a greater degree, the supply and transport of sediment in the L ower M issouri River system (J acobson and others, 2009; M eade and M oody, 2010; N ational Research Council, 2011). The al tered sediment regime included a substantial decrease in the mass of transported sediment (a reported 70 percent decline in sediment transported by the M issouri River to the M ississippi River since the 1950s), sediment deposition in the main-stem reservoirs, channel bed and bank erosion downstream from dams, and accretion and storage of sediment behind revetments and other river control structures (M eade and M oody, 2010).

Sediment supply, sediment transport, and stream-channel dynamics are physical processes that are interrelated in natural fluvial systems, and an alteration of one component leads to a readjustment of the remaining factors. In a free-flowing, dynamic stream system, these changes occur continuously at a variety of temporal and spatial scales. M onitoring programs by the U.S. Geological Survey (USGS), in cooperation with the U.S. A rmy Corps of Engineers (USA CE) and other Federal, State, and local agencies, quantify sediment and streamflow characteristics at stations within the M issouri River B asin. The

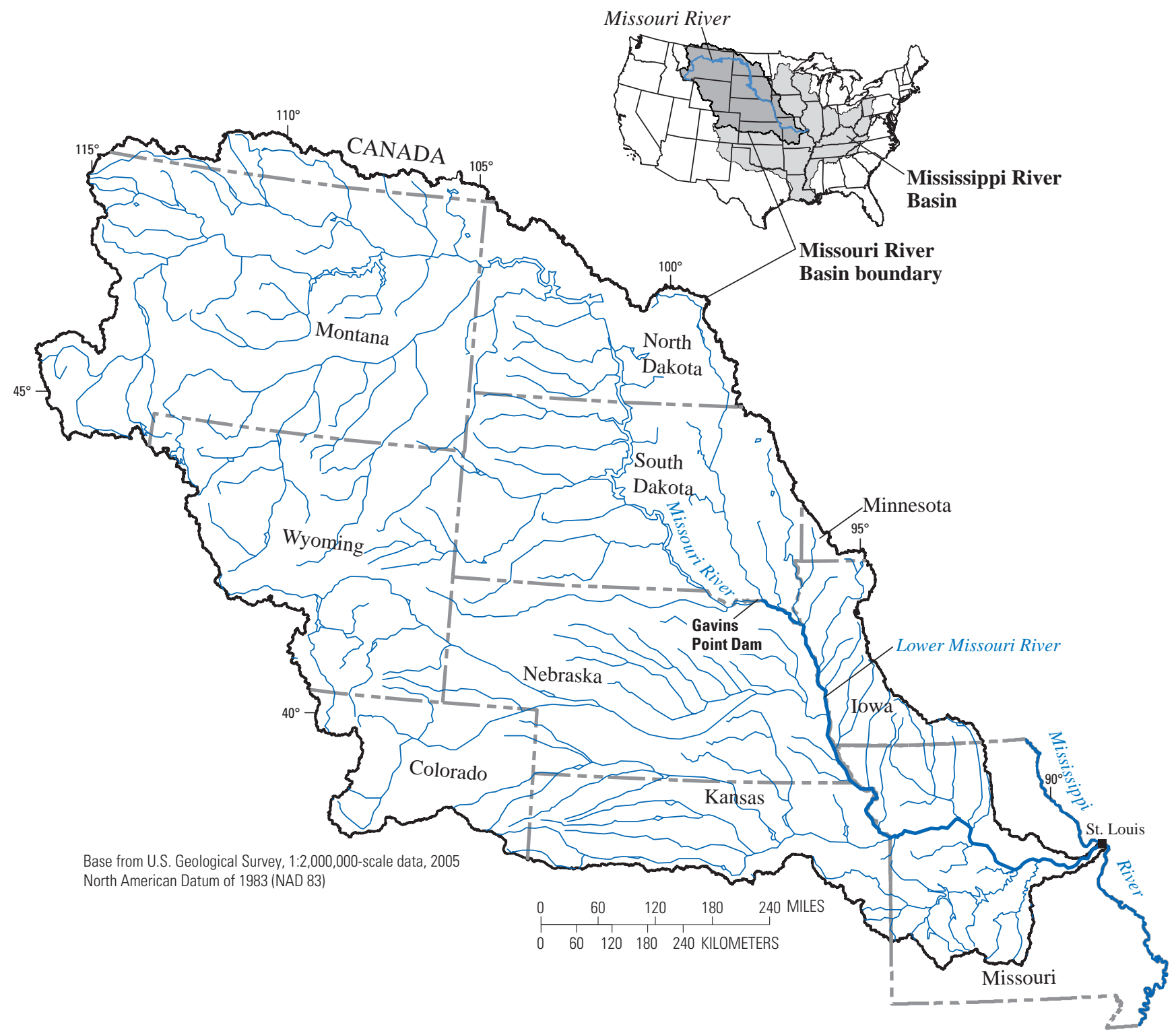

Figure 1. Missouri River Basin and Lower Missouri River reach (downstream of Gavins Point Dam). 
streamflow record is more extensive and complete than the sediment record, but the record of both physical characteristics spans 8 decades at some locations in the basin.

Sediment transport is an integral component of numerous management activities and issues within the M issouri River system. Some of the activities and issues include bed degradation, dredging operations, maintenance of a navigation channel, habitat restoration actions (creation and evolution of emergent-sandbar and shallow-water habitats), nutrient transport, and riparian vegetation dynamics. A $n$ informative aid in the management of these and other issues involving sediment in the M issouri River is a sediment budget quantifying the components of sediment transport during a defined time interval. Describing and quantifying sediment transport processes within a defined control volume (channel reach) can be defined in the simplest form by the following equation:

$$
\Delta \operatorname{Mass}(\mathrm{t}) / \Delta \mathrm{t}=\operatorname{SEDin}(\mathrm{t})-\operatorname{SED} \text { out }(\mathrm{t})+\mathrm{Gain}(\mathrm{t})-\operatorname{Loss}(\mathrm{t})(1)
$$

where

\begin{tabular}{|c|c|}
\hline $\operatorname{Mass}(\mathrm{t}) / \Delta \mathrm{t}$ & $\begin{array}{l}\text { is the budget residual indicating the rate of } \\
\text { change in the total mass of unmeasured } \\
\text { sediment in the reach with the time interval } \\
\Delta \text { tincluding storage; }\end{array}$ \\
\hline SEDin(t) & $\begin{array}{l}\text { is the input sediment mass, integrated with } \\
\text { time }(t) \text {; }\end{array}$ \\
\hline $\begin{array}{r}\text { SED out(t) } \\
\text { Gain }(\mathrm{t})\end{array}$ & $\begin{array}{l}\text { is the output mass, integrated with time }(t) ; \\
\text { refers to sediment mass inputs within the } \\
\text { reach including those from tributaries, } \\
\text { integrated with time }(t) \text {; and }\end{array}$ \\
\hline $\operatorname{Loss}(t)$ & $\begin{array}{l}\text { refers to within-reach sediment mass losses } \\
\text { including those from commercial dredging } \\
\text { withdrawals, integrated with time (t). }\end{array}$ \\
\hline
\end{tabular}

The most complete sediment data record for $M$ issouri River Basin stations historically, and currently (2016), exists at main-stem stations and includes the suspended part of SEDin and SED out variables in equation 1, with information more limited for all reach Gain and Loss variables. Depending on the sediment transport characteristics of a particular reach and the time interval, the $\Delta \mathrm{MASS} / \Delta \mathrm{t}$ may represent equilibrium, degradation, or aggradation conditions as defined in figure 2 .

\section{Sediment Sampling and Accounting in the Missouri River Basin}

The compilation of the various sediment budget components is complicated by the challenges of measuring sediment that is being transported by multiple mechanisms. The total sediment load of a fluvial system can be categorized in several ways based on origin, means of transport, and sampling method (fig. 3). The sediment sampling programs led by the USACE and then USGS within the M issouri River Basin have focused on defining sediment load based on sampling method and the suspended part of total load.

The routine sediment monitoring program in the basin has included the collection of suspended-sediment concentrations (SSCs), suspended-sediment particle sizes, computed suspended-sediment loads (SSLs), and bed-sediment sizes at selected main-stem and tributary stations. To obtain information on total sediment loads, information on bedload transport has been estimated by theoretical computations or discrete bedload samples at main-stem stations.

The primary form of sediment transport in the M issouri River is the suspended part of total load, and the primary means by which sediment transport has been accounted for in the basin is SSLs. The SSL s primarily have been computed using methods described in Porterfied (1972) and a daily SSC (either measured or estimated) multiplied by the corresponding daily streamflow to obtain a daily SSL. The daily SSLs were then summed to obtain monthly or annual SSLS.

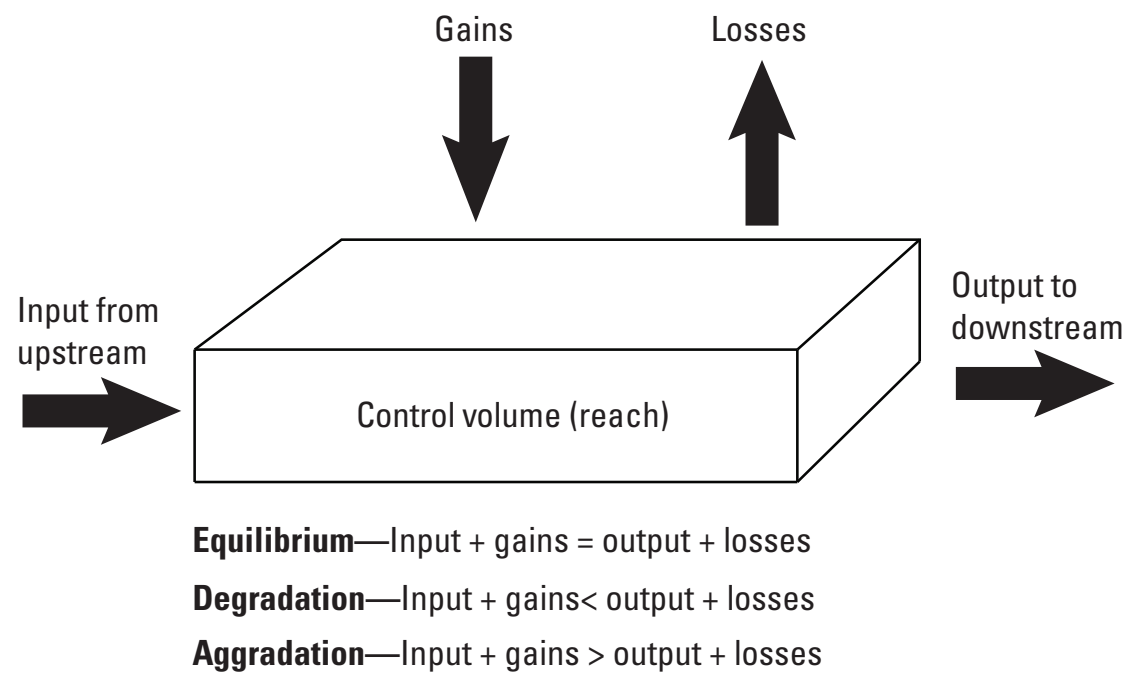

Figure 2. Schematic showing components of sediment budget for a river reach. Figure modified from Ohlmacher (1998). 


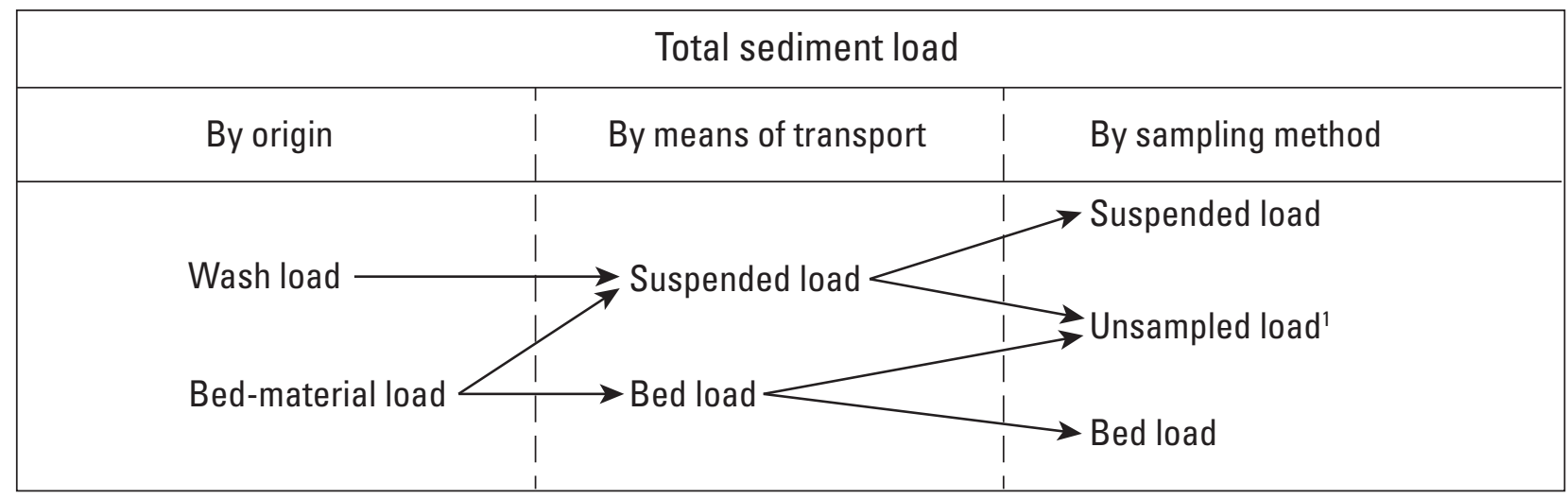

'That part of the sediment load that is not collected by the depth-integrated suspended-sediment and pressure-difference bed-load samplers used, depending on the style and size of the sampler(s).

Figure 3. Categories of total sediment load (Diplas and others 2008).

A continual trace of SSCs (sedigraph) is devel oped for the period of interest using discretely sampled SSCs, daily observed SSCs, and estimates of SSCs for intervals between each sample collection. These estimates of SSCs are made using a relation of streamflow to SSC known as a sedimentrating (sediment transport) curve as described by Horowitz (2003)

Sampling of SSC and computation of SSL were led by the USACE at M issouri River Basin stations from the late 1930s through the 1970s, and thereafter were led by the USGS. The SSC sampling interval, timing, and frequency has differed considerably at stations and between stations. The SSC sampling frequency at stations within the M issouri River Basin has differed from daily to about monthly and has differed temporally at a station and among stations. Sampling frequency has tended to be greater at main-stem stations than at tributary stations. Depth-integrated samples (continuous samples obtained from the vertical water column and from multiple sample locations [verticals] along a river transect), and point samples (samples obtained from selected depths or points in the water column at multiple verticals) were used in the collection of SSC and particle-size data. The number of sampled verticals differed by station; but, generally, the number of sample verticals was three to five. All suspendedsediment samples collected after the mid-1950s were obtained isokinetically (stream water entering the sampler nozzle did not differ in velocity from that of the water column). The spacing of the sampled verticals generally was based on equal-discharge increment divisions or equal-width increments (Edwards and Glysson, 1999). L aboratory methods for the analysis of fluvial sediment samples to obtain SSC and particle size are provided in Guy (1969).

Since 2006, SSLs at select stations within the M issouri River Basin have been computed using continuous sampling of optical backscatter (turbidity). Such continuous surrogate methods (see Surrogate M ethods for Determination of Sediment Transport" section) provide the opportunity to refine SSL computations to shorter (for example, hourly) estimates, provide a higher correlation with SSC than that between SSC and streamflow, and reduce possible hysteresis effects (referring to the lower SSC s on recession limb of a hydrograph compared to the rising limb for the same flow) common in the SSCstreamflow relation. Additional sediment data collected with less regularity and frequency at M issouri River B asin sediment stations are suspended-sediment particle size samples, bed-sediment particle-size samples, and bedload samples or estimates.

Sediment sampling within the M issouri River Basin has historically focused on active transport of suspended material within the water column of free-flowing reaches; however, sediment storage also can be an important component of sediment budgets. M issouri River main-stem reservoir storage changes have been periodically assessed (U.S. Department of A griculture, 2009), and L ower M issouri River channel volume changes have been periodically estimated (J ohn Shelley, U.S. A rmy Corps of Engineers, written commun., 2015). Flood-plain deposition and erosion along the M issouri River is unquantified; however, characteristics of these processes are related to the frequency and magnitude of flooding, channel hydraulics, distance from channel, local relief, and vegetation characteristics. If the reach is in equilibrium, the long-term net change in storage should be near zero, and the el evation of the flood plain remains stable relative to the elevation of the channel bed (Wolman and Leopold, 1957). Equilibrium also can exist when channels actively migrate if deposition equals erosion. Under channel degrading conditions, which is a condition present in much of the L ow er M issouri River between 1990 and 2005 (U.S. A rmy Corps of Engineers, 2009), the opportunity for flooding and flood-plain storage is diminished. Factors that have historically affected the flood-plain storage component of the Lower $M$ issouri River are regulation of flows by the impoundments, levees, and the BSNP. The BSNP increased the flood-plain storage component and resulted in the accretion of Missouri River flood plain between 1912 and 
1981 (Ferrell, 1996) at an average rate estimated to be equivalent to 14-33 percent of pre-dam annual SSL $s$ at the M issouri River at Hermann, M o. (J acobson and others, 2009).

Indications are that despite modifications in the hydrology and sediment transport characteristics of the L ower Missouri River, substantial amounts of flood-plain sediment storage still takes place in localized areas during flooding (A lexander and others, 2013; Schalk and others, 1998). The post-impoundment Lower Missouri River flows are highly regulated in comparison to the historical flow frequency, magnitude, timing, and duration characteristics (J acobson and others, 2009). Sedimentation characteristics associated with flooding can vary longitudinally depending on the source of flooding and contributions from tributaries. Average deposition on the Lower Missouri River flood plains has not been assessed and is unknown, and such losses are not subject to offset from gains that result from channel migration as the losses might on a nonchannelized river. Except for upper reaches of the L ower M issouri River (upstream from Sioux City, lowa) and constructed side channels, bank stabilization is ubiquitous on the L ower M issouri River and generally eliminates bank erosion as a source of suspended sediment.

\section{Need for Study}

The sediment budget of a river reach, and the associated equilibrium status, will vary longitudinally and temporally; therefore, to have an understanding not only of the predominant transport conditions in a reach of interest but also to have the ability to detect change within a time frame and reach of interest is important. A s impetus for this study, the $\mathrm{N}$ ational Research Council (2011) documented that
"Corps of Engineers and the U.S. Geological Survey scientists have been conducting val uable collaborative investigations of $\mathrm{M}$ issouri River sedimentary processes that should be used as the foundations for a more detailed and extensive sediment budget. Over time, continued collaboration may lead to a more formal program for data collection and evaluation. The Corps and the USGS should extend their collaborative efforts and develop a detailed M issouri River sediment budget for the headwaters to the river's mouth, with provisions for continuing revisions and updates as new data become available."

J acobson and others (2009), when referring to the need for sediment information in restoration activities on the M issouri River, documented that

"Sediment budgets - an accounting of sediment transport, erosion, and deposition - are fundamental to understanding geomorphic evolution of altered river systems."

A sediment budget, developed from the extensive existing sediment data collected at M issouri River main-stem and primary tributary stations, is a first step toward addressing these stated information needs. Such generalized suspendedsediment budgets of the M issouri and M ississippi Rivers have been determined for selected periods in previous studies (figs. 4-5). The process of developing such a sediment budget and the likely applications of such a tool also provide a means of assessing temporal and spatial data gaps and limitations.

As an initial step toward the attainment of a detailed $M$ issouri River sediment budget, the USGS, in cooperation with the USA CE K ansas City and O maha Districts, developed

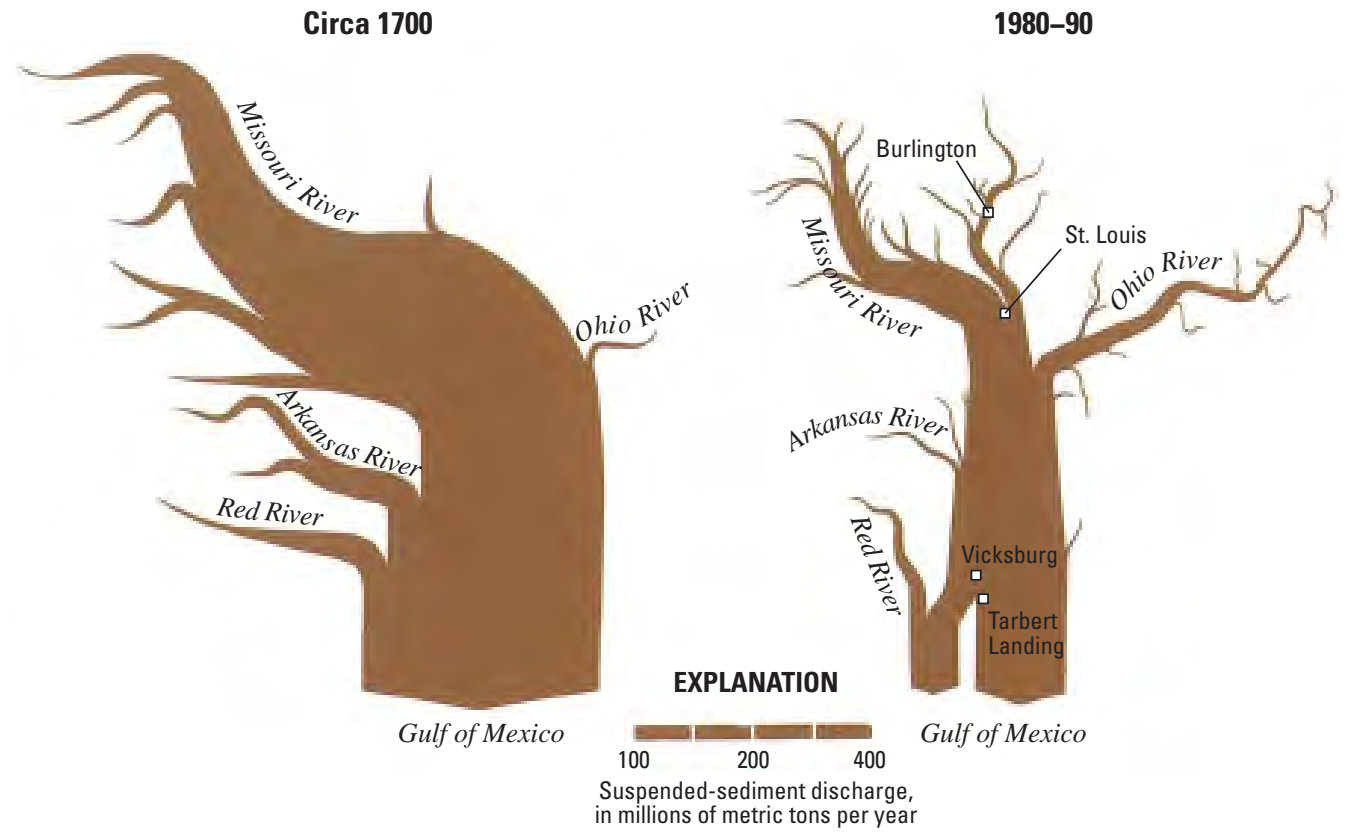

Figure 4. Suspended-sediment budget of the Mississippi River Basin (Meade, 1995). 


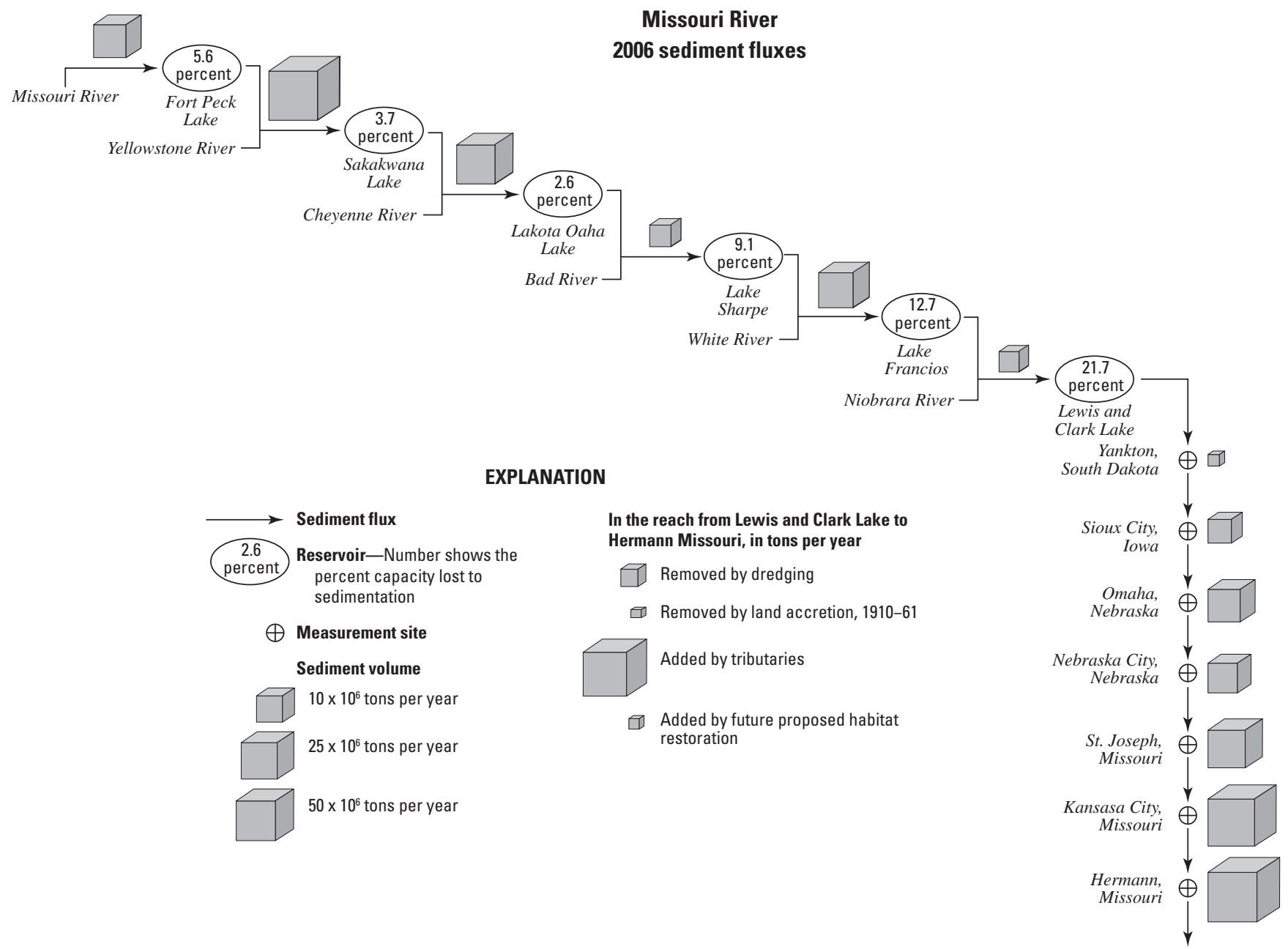

Figure 5. Generalized framework for a Missouri River sediment budget (National Research Council, 2011).

a generalized sediment budget for the L ower M issouri River using existing sediment data. The primary objectives of this effort are indicated in the following list.

1. Use the best available information to establish the initial framework for a sediment budget with which to update the National Research Council (2011) conceptual sediment budget.

2. The quantification of bedload transport is of importance in understanding M issouri River channel bed dynamics. When and where possible, incorporate the bedload part of total sediment load into a generalized sediment budget.

\section{Purpose and Scope}

The purpose of this report is to summarize the results of a study that was completed to determine sediment budgets of the L ower M issouri River. The sediment budgets include suspended-sediment data and, when and where available, bedload data. The scope of the study includes the development of a long-term (1968-2014) post-impoundment budget for mainstem reaches within the L ower M issouri River- from Yankton, S. Dak., to St. L ouis, M o. Included in the analysis are 31 $M$ issouri River main-stem and tributary stations and $2 \mathrm{M}$ ississippi River stations- the M ississippi River below Grafton, III., station and the M ississippi River at St. Louis, M 0., station. Example sediment budgets for annual, monthly, and daily periods are presented for a selected L ower M issouri River reach. The available sediment data at the study sites were compiled; annual loads were computed as needed and data supported it. Temporal changes in SSC $s$ and SSL $s$ were assessed for 1930-2014 to put the post-impoundment period in temporal context, and reach-by-reach sediment budgets were developed. Data gaps and uncertainties in the development of an annual, monthly, and daily suspended-sediment and bedload budgets are presented, and surrogate sediment data collection methods also are discussed. 


\section{Study Methods}

The main-stem reservoirs on the M issouri River effectively trap sediment and have greatly altered the sediment transport regime of the river. The L ower M issouri River, the section of river downstream from $G$ avins Point $D$ am, the downstream-most main-stem dam was, therefore, selected for the determination of a sediment budget in this study (fig. 1). Stations selected for the study, data availability, and methods used in determining budget components and sediment budgets for long-term, annual, monthly, and daily periods are described in the following sections of this report.

\section{Station Selection}

Sediment monitoring stations within the L ower M issouri River Basin and beyond used in the development of a sediment budget were selected from main-stem and tributary stations based on available record. L ower M issouri main-stem stations used in the study included the following stations: Yankton, S. Dak. (USGS station identification 06467500); Sioux City, Iowa (USGS station identification 06486000); Omaha, Nebr., (USGS station identification 06610000); Nebraska City, Nebr. (USGS station identification 06807000); St. Joseph, Mo. (USGS station identification 06818000); Kansas City, Mo. (USGS station identification 06893000); Hermann, Mo. (USGS station identification 06934500). These stations are hereafter referred to as "Yankton", "Sioux City", "Omaha", "N ebraska City", "St. J oseph", "K ansas City", and "Hermann" stations. In the case of tributary stations, selection criteria also included the size of drainage area (greater than 250 square miles) and station location (most downstream sediment station on a tributary). The two stations on the M ississippi River, the M ississippi River below Grafton, III. (USGS station identification 05587455) and Mississippi River at St. Louis, Mo. (USGS station identification 07010000), also were selected to determine the contributions of the M issouri River and upper M ississippi Rivers to the sediment loads of the M ississippi River at St. L ouis, M o., station. These stations are hereafter referred to as "Grafton" and "St. Louis". M easured or estimated sediment data from 33 selected USGS stations (8 M issouri River main-stem, 23 tributaries, and $2 \mathrm{M}$ ississippi River stations) were used in the study analyses (fig. 6). Characteristics, sediment data availability, and corresponding annual average flows for the 33 stations are listed in table 1.

\section{Sources of Sediment Data}

The primary sediment data used in the development of sediment budgets are SSL $S$ computed and published by the USA CE and USGS. B edload data are limited to discrete measurements or theoretical estimates made for main-stem stations. Other miscellaneous sediment data, including commercial dredging data and reintroduced sediment data associated with M issouri River Recovery Program (M RRP; U .S. A rmy Corps of Engineers, 2015) activities are incorporated in the sediment budgets where available. The sources and availability of sediment data used in this study are described in the following sections.

\section{Annual, Daily Suspended-Sediment Loads}

The primary sediment data used in the determination of sediment budgets for the L ower M issouri River are historical SSL s from main-stem and tributary stations. The earliest SSL record used in this study was from 1930 to 1931 and published by the Chief of Engineers (1935). The USA CE calculated and published daily sediment loads for M issouri River Basin sediment stations from 1937 to 1974 (U.S. A rmy Corps of Engineers, 1951; 1957; 1965; 1970; 1972; 1976). A nnual SSLs were calculated for this study at stations where SSL $s$ were not published but SSC and streamflow data were available. Post-1974 sediment loads calculated by the USGS generally were determined by the subdivision (Porterfield, 1972) method using SEDCA LC (K oltun and others, 1994) or GCLA S software (K oltun and others, 2006). Since 2006, daily loads for select stations (the number of selected stations differs by year; generally about 5 stations) al so have been computed by USGS using the turbidity surrogate method (Rasmussen and others, 2009). A nother method used for the determination of annual SSLs was L OA DEST software (R unkel and others, 2004). For this study, the method was used at stations for which SSC and streamflow data were collected but loads were not previously computed. The S-LOA DEST version of the program, written for the commercial statistical package TIBCO Spotfire S+ (TIBCO Software Inc., version 8.1), was used to compute SSL estimates as described by Heimann and others (2010). The LOADEST incorporates explanatory variables of streamflow (a linear or quadratic relation), time (a linear or quadratic relation), and seasonality into one of nine predefined regression models. The L OADEST estimates include a measure of predictive uncertainty, and the 95-percent confidence levels and associated coefficient of variation of annual SSLs for selected stations in the M issouri River Basin are provided in Heimann and others (2010) and Heimann and others (2011). A nnual SSL s primarily were used in the determination of the sediment budgets used in this study. These data are summarized by station in table 2 along with the 1968-2014 computed or estimated average SSL and an overall coefficient of variation (ratio of standard deviation to mean). A vailable daily SSL s for the selected stations are provided in table 3.

During the post-impoundment budget period, 6 of the 33 selected stations had complete annual SSL record, including 5 of the 8 main-stem stations (Sioux City, Omaha, Nebraska City, St. Joseph, and Hermann) and 1 of the 23 tributary stations (Platte River at L ouisville, N ebr.). F or this study, the post-impoundment budget period is water years 1968-2014 (a water year is the 12-month period from October 1 , for any given year, through September 30 , of the following 


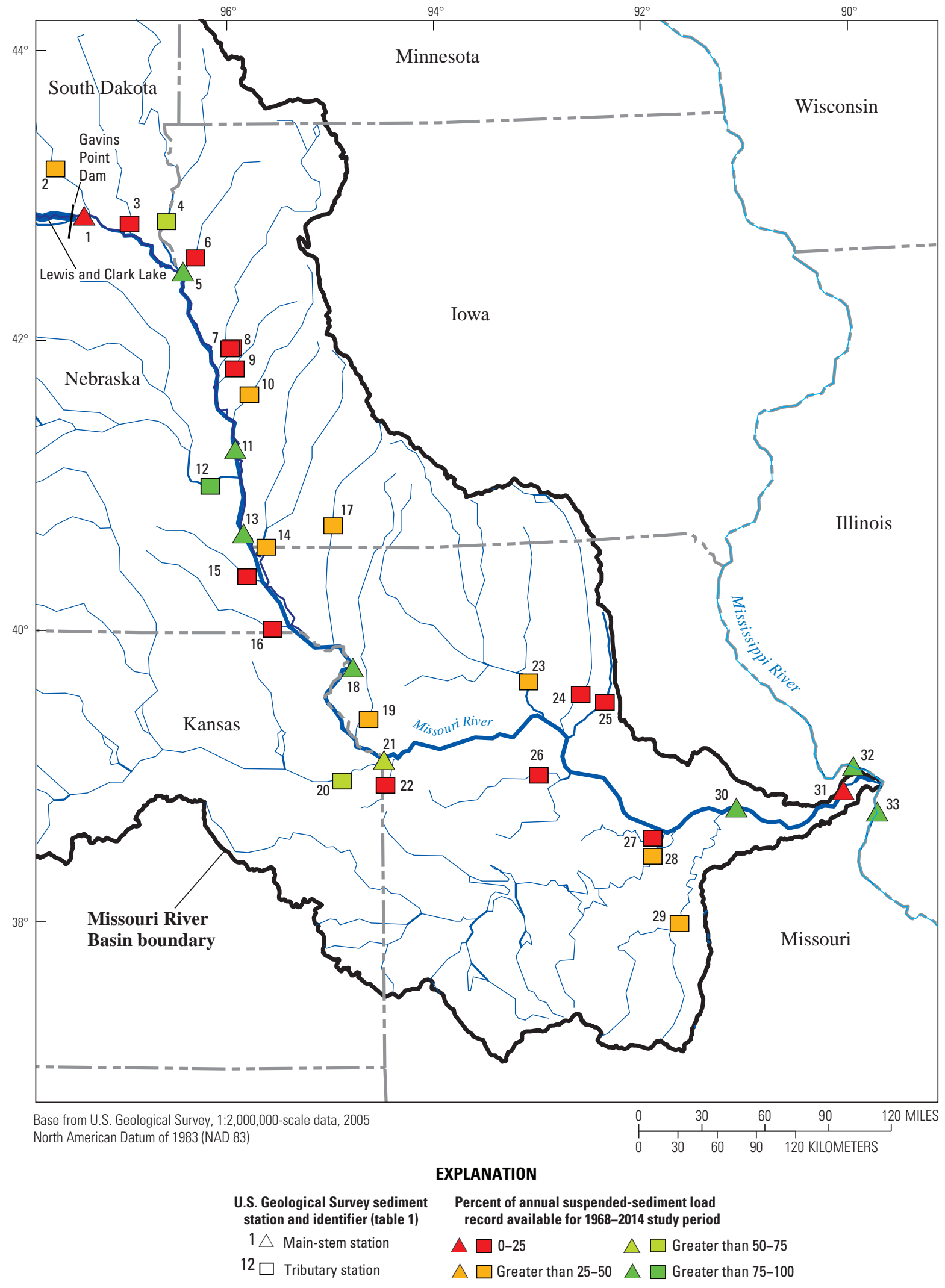

Figure 6. Sediment monitoring stations used in sediment budget analyses and annual sediment load availability, Lower Missouri River Basin, 1968-2014. 
year; the water year is designated by the calendar year in which it ends). During 1968-2014, 22 of the 33 stations used in the analysis had less than 50 percent annual SSL record available, and the average annual station SSL availability was 45 percent. The longest period of concurrent availability of annual SSL data among the selected stations was during 1966- 92 water years (table 1). Despite SSC data being used in the computation of historical published sediment loads, the SSC s generally were not published or retained, and, therefore, the availability of SSC data is more limited than SSL data (table 1). A verage station availability of daily SSL $s$ during the post-impoundment analysis period was 22 percent. M ost daily SSL record was pre-1980, and the maximum availability was during the 1948-51 water years (table 1). Of the 33 selected stations, 14 stations (all but one station are tributary stations) did not have daily SSL data available during the postimpoundment analysis period.

A long-term average annual SSL was estimated for four major Missouri River tributaries (Vermillion River, Soldier River, Big N emaha River, and Little Nemaha River; (table 2) because stations on these tributaries lacked SSC and SSL data during 1968-2014. A n estimated average annual SSL for 1968-2014 at the Vermillion River near Vermillion, S. Dak., station was determined by taking the ratio of concurrent streamflow at this station and at the Big Sioux River at Akron, lowa, station times the long-term SSL at the Big Sioux River at A kron, lowa station. The long-term SSL at the Big Nemaha River at Falls City, N ebr., station was determined by taking the ratio of concurrent SSL record with the Platte River at L ouisville, Nebr., station outside of the 1968- 2014 computation times the long-term SSL for the Platte River at L ouisville, N ebr., station. The SSL at the Little N emaha River at A uburn, N ebr., station was determined by taking the ratio of 19682014 streamflows for the Little Nemaha at Auburn, Nebr., and Big Nemaha River at Falls City, N ebr., stations times the long-term SSL estimate for the Big N emaha River at Falls City, N ebr., station. Similarly, an estimated long-term SSL for the Soldier River at Pisgah, lowa, station was determined by taking the ratio of concurrent SSL record with the B oyer River at L ogan, lowa, station times the long-term SSL for the B oyer River at Logan, lowa, station. The associated uncertainty of these estimates is substantial and may approach 100 percent.

\section{Bedload data}

The counterpart to SSL in the determination of total sediment load by the sampling method is bedload (fig. 3). Bedload is defined as "the sediment that slides, rolls, or skips along in al most continuous contact with the streambed" (Hubbell, 1964). A consistent bedload sampling program does not exist on the lower M issouri River, and available data are sparse, sporadic, and limited only to M issouri River main-stem stations (tables 1 and 4). Some bedload measurements (BL-84 sampler) have been made in the upper sections of the L ower M issouri River (Galloway and others, 2013; Rus and others, 2015), and recent (2010-14) longitudinal surveys of bedload transport have been led by the USA CE using time-sequenced bathymetric techniques (A braham and Pratt, 2010; A braham and others, 2010; J ohn Shelley, U.S. A rmy Corps of Engineers, written commun., 2015) and the Integrated Section Surface Difference over Time version 2 (ISSD 0TV2) method (A braham, 2009). M uch of the available L ower M issouri River bedload data, however, are theoretical estimates calculated by means of a variety of formulae and the modified Einstein procedure (Einstein, 1950; Colby and Hembree, 1955) is used most consistently. Such theoretical values include estimates of bedload and the unmeasured load (fig. 3) as the values were determined by subtracting the measured SSL from the theoretical total load. Available bedload data, including measured and theoretical values, cover a substantial range of flows at each station that the data were obtained and, collectively, cover a temporal range from 1950 to 2014 (table 4).

B edload in large, low gradient rivers has been estimated to range from less than 5 percent (Holmes, 1996; Nittrouer and others, 2008) to 8 percent (Gaeuman and J acobson, 2007) of the total sediment load. In studies of sediment transport during the 2011 flood and post-flood periods, bedload measured at L ower M issouri River sites using a B L-84 sampler generally was less than 13 percent of total load and differed greatly with flow and by site (Galloway and others, 2013; Rus and others, 2015).

\section{Miscellaneous Sediment Data}

The removal of sediment from the L ower M issouri River by commercial dredging activities has been well documented; however, quantities of other possible sediment gains and losses are estimated (side-channel chute development, channel storage) or unknown (flood-plain storage). Commercial dredging information was available by reach (from N ebraska City, N ebr., to the mouth) and by water year for 1974 through 2014 (table 5); J ohn Shelley, U.S. A rmy Corps of Engineers, written commun., 2015). A nnual cal endar-year totals by reach were available for 1974-97, and monthly totals by reach were available for 1998-2014. The average monthly distribution of the annual dredging totals for 1998-2014 were used to discretize the annual 1974-97 totals into estimated monthly values. These monthly estimates then were used to compute commercial dredging totals by water year for 1974-97. The average of 1974-80 water year dredging totals, by reach, was used as an estimate for 1968-73 values. Channel-bed dredging involves the removal and disruption of bed material in storage within the control volume (consisting of a river reach defined upstream and downstream by main-stem stations and laterally by the extent of the active flood plain). In terms of the effect of dredging on the M issouri River sediment budget, the direct 
loss of material from the reach control volume is obvious, but the possible secondary effects of dredging on the suspendedsediment and bedload components presented in this study are unquantified. The disturbances and losses to the volume of channel-bed material may result in increases, decreases, or no net effects on SSL $s$ and bedload transport at the downstream station nearest to the activity.

In response to riverine and flood-plain habitat losses resulting from the BSNP (Ferrell, 1996), the USA CE began restoring shallow-water habitat in the L ower M issouri River in the mid-1990s through the MRRP. The MRRP projects may reintroduce sediments that were accreted from the BSN $P$ (1912-81), which overlapped the budget analysis period (1968-2014). Some transported sediments, therefore, could potentially have been deposited and later reintroduced within the long-term budget analysis period and be considered a nonet change in storage within the control volume. The M RRP efforts include a variety of channel modifications including side-channel chutes, dike notches, and revetment chutes. Reintroduced material is primarily associated with side-channel chute construction, and contributions from the chute projects were based on documented direct inputs during chute construction and an estimated erosion rate of side-cast materials. Chute development and erosion was estimated based on timelagged bathymetric surveys or on the chute target dimensions and an estimated rate of erosion as described in Heimann and others (2015). The temporal range of side-channel chute data is from 1993 through 2014, and the spatial extent is within reaches downstream from Sioux City, lowa (table 6).

Missouri River channels and flood plains can serve as reach budget storage or sediment sink (loss) or sediment source (gains), and this budget component is highly variable temporally and spatially. The quantity of flood-plain storage and the retention period of sequestered sediments in the postimpoundment Lower Missouri River are poorly quantified and are inferred from the reach budget residuals, as are other unmeasured budget components and errors. M issouri River bed volume and mass change have been quantified through periodic longitudinal channel surveys. B ased on M issouri River channel-bed surveys led by the USA CE in 1994, 2007, 2008, 2009, 2012, 2013, and 2014 (J ohn Shelley, U.S. A rmy Corps of Engineers, written commun., 2015), and by using an estimated bed density of 97 pounds per cubic foot, the annual channel storage change of selected reaches accounted for -8.6-14.8 percent of annual SSL $s$ at reach input stations (table 7).

\section{Temporal Variations in Suspended-Sediment Loads and Concentrations}

Qualitative temporal variations in SSL s and SSCs were assessed, where available, to put the 1968-2014 budget period in historical context. Annual SSLs and annual flow-weighted concentrations (computed by dividing annual SSL by annual flow) were plotted with time during 1930-2014 to indicate changes in loads and concentrations, including changes resulting from impoundments. The flow-adjusted SSCs (the residuals from a simple linear regression model of observed SSCs using streamflow as the explanatory variable, expressed in milligrams per liter) at main-stem stations for 1968-2014 also were determined. The observed SSC and streamflow values used in the analyses were obtained from the USGS N ational Water I nformation System (N WIS) database at http:/ dx.doi.org/10.5066/F 7P55K J N. Q ualitative temporal relations in flow-adjusted SSCs (depicted using a second-order polynomial curve fitted to the residuals) can be used to evaluate the magnitude and duration of changes in observed SSCs resulting from effects other than changes in flow.

\section{Determination of Sediment Budgets}

A sediment budget residual was computed for budgets of multiple time intervals by applying equation 1 to a defined control volume. The control volume consisted of a river reach defined upstream and downstream by main-stem stations and laterally by the extent of the active flood plain.

The sediment budget residuals, representing the $\Delta$ Mass/ $\Delta t$ variable in equation 1 and expressed in tons per budget time interval, were determined by taking the input station SSL; adding the corresponding bedload (if known) and the known gains from tributaries and M RR P activities; and then subtracting known losses from commercial dredging, the output bedload (if known), and the output station SSL. Although the sediment budget residual is determined from simple addition and subtraction of the components in equation 1 , the various components represent a variety of particle-size classes and transport mechanisms. M eade and M oody (2010) also indicated that a shortcoming of depictions of sediment transport is the spatial presumption of hydraulic connectivity from source to sink; however, in reality, sediment travels in episodic pulses of varying time scales.

The sediment budget residuals included the change in sediment storage in the reach during the specified time interval, included the unmeasured gains and losses, and included the errors in the measurement and calculation of the measured components. Developed sediment budgets, all using equation 1 but with varying values for $\Delta \mathrm{t}$, included an average annual post-impoundment sediment budget (1968-2014 water years) for all reaches between the Yankton and St. L ouis stations and included example annual (1968-2014 water years), monthly (1968-76 water years), and daily (1968-76 water years) budgets for the Omaha, N ebr., to N ebraska City, N ebr., reach. For the long-term and annual budgets, the net budget residuals are compared to the stage trend (U.S. A rmy Corps of Engineers, 2012) for average flows at the corresponding main-stem Missouri River stations within the analysis reach, to determine if the sign of the two indicators are in agreement. D etails of the development of each budget period presented in this study are discussed in the following sections. 


\section{Average Annual Post-Impoundment Sediment Budget}

A single sediment budget residual (in tons) was calculated using available data for the primary budget components in equation 1 for each of seven main-stem reaches in the average annual post-impoundment (1968-2014) sediment budget. A $n$ average annual SSL for the 47 years was determined for each station (table 2). The L ower M issouri River and M ississippi River main-stem station values represented the "SED in" and "SED out" components in equation 1 and the average annual tributary value, the "Gains". A vailability of annual record at main-stem stations used in the budgets averaged 87 percent. A vailability of annual record at tributary stations during 1968-2014 used in the study averaged 28 percent. Sediment contributions from about 2 to 65 percent (average 20 percent) of the local drainage areas of the main-stem reaches was unaccounted for in the sediment budgets resulting in an underestimation of the actual reach "Gain" component. Additional quantified "Gains" included estimated reintroduced material from the M RRP, and "Losses" included commercial dredging removals by reach.

A veraged post-impoundment bedload transport was included in three reach budgets using published bedloadstreamflow data sets computed with the modified Einstein procedure. The post-impoundment bedload (plus unmeasured part of total load) estimates for the N ebraska City, St. J oseph, K ansas City, and Hermann stations were computed using bedload values developed for a range of flow conditions (ENTRIX, Inc., 2011) using 1994-2009 averaged sediment data. These data allowed for the inclusion of a bedload estimate in three post-impoundment reach budgets ( $\mathrm{N}$ ebraska $\mathrm{City}$ to $\mathrm{St}$. J oseph stations, St. Joseph to $\mathrm{K}$ ansas City stations, and $\mathrm{K}$ ansas $\mathrm{City}$ to Hermann stations) and also provided consistency in computation methods and resulting bedload estimates among reaches.

\section{Annual, Monthly, Daily Sediment Budgets}

The computation of budget residuals at shorter time scales (annual, monthly, and daily) could better capture the episodic nature of sediment transport not seen in long-term averaged data. A nnual, monthly, and daily sediment data were limited to main-stem station inputs and outputs for most reaches in the L ower M issouri River. The reach between the O maha and N ebraska City stations was selected to provide an example of an annual budget because a single primary Gain (tributary) - the Platte River - is within the reach, and because annual SSL data were available for the Platte River at L ouisville, N ebr. station. Information regarding annual sediment storage was unavailable in the reach and the reach was not commercially dredged. The annual reintroduction of sediments as a result of chute construction was estimated to have been between 2000 and 2009 in the reach and was included in the annual budget. A nnual bedload estimates were unavailable for the M issouri River at O maha, N ebr., station during the analysis period, so this component was not quantified. The
47 annual budget residuals for 1968-2014, therefore, include unquantified net changes in storage, in bedload, and in errors in the measurement and computation of SSL $s$.

Similar to the determination of annual sediment budgets, examples of monthly and daily sediment budgets also were determined for the reach between the O maha and N ebraska City stations using equation 1 . M onthly and daily data for SSL components in this reach budget were available for 1968-76.

Storage and bedload values were unknown, commercial dredging did not take place in this reach, and M RRP activities also did not take place in this reach during 1968-76.

\section{Sediment Budgets of the Lower Missouri River}

Sediment budgets for the L ower M issouri River that include long-term (1968-2014), annual, monthly, and daily budgets are presented. N umerous data gaps exist in the sediment record (table 1) used in the devel opment of the budgets, and the temporal changes in SSC $s$ and SSL $s$ were determined at selected stations during 1930-2014 to put the available data in historical context.

\section{Temporal Changes in Suspended-Sediment Concentrations and Loads}

The sediment record for the post-impoundment budget period is far from complete for most stations; therefore, to view the temporal changes in the partial available record, it is useful to infer a longer term temporal context. The decline in SSC and SSL at M issouri River main-stem stations with time has been well documented (K eown and others, 1986; M eade and M oody, 2010). Causes for the declines have been attributed to main-stem impoundments, tributary impoundments, and erosion control measures. Post-impoundment (1968-2009) declines in SSC s at selected M issouri River stations were from 54.9 to 99.7 percent, and declines in SSL $s$ at selected stations were from 50.5 to 99.8 percent compared to pre-impoundment values (Heimann and others, 2011). Similarly, declines in SSC s were from -54.9 to -93.2 percent and SSL $s$ were from -50.5 to -89.2 percent at selected tributaries during the same period (Heimann and others, 2011).

Temporal changes in annual, flow-weighted SSC and annual SSL values for the study sites indicate declining SSC and SSL values at most stations during 1930-2014 (figs. 7-8). Because most temporal changes in sediment loads and flow-weighted concentrations were downward (figs. 7-8) and because most missing record was in the latter part of the analysis period (table 1), the use of partial record at some tributary stations as an average long-term estimate could possibly overestimate the actual long-term average SSL values. Exceptions to this apparent systemic decline in sediment 

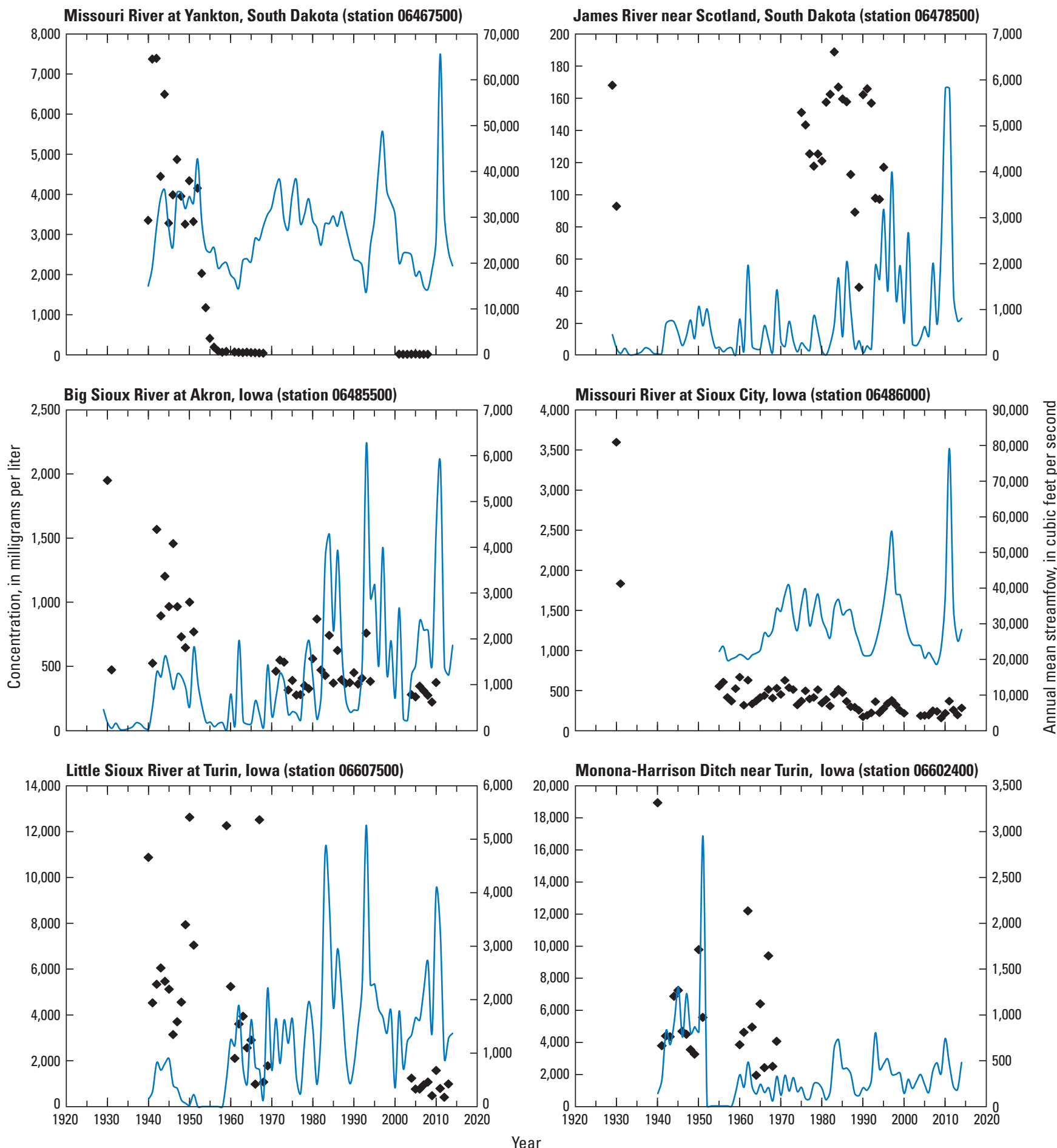

EXPLANATION

- Annual average streamflow

- Flow-weighted suspended-sediment concentration

Figure 7. Temporal changes in flow-weighted suspended-sediment concentrations at selected stations in the Missouri and Mississippi River Basins, 1930-2014. 
Soldier River at Pisgah, lowa (station 06608500)
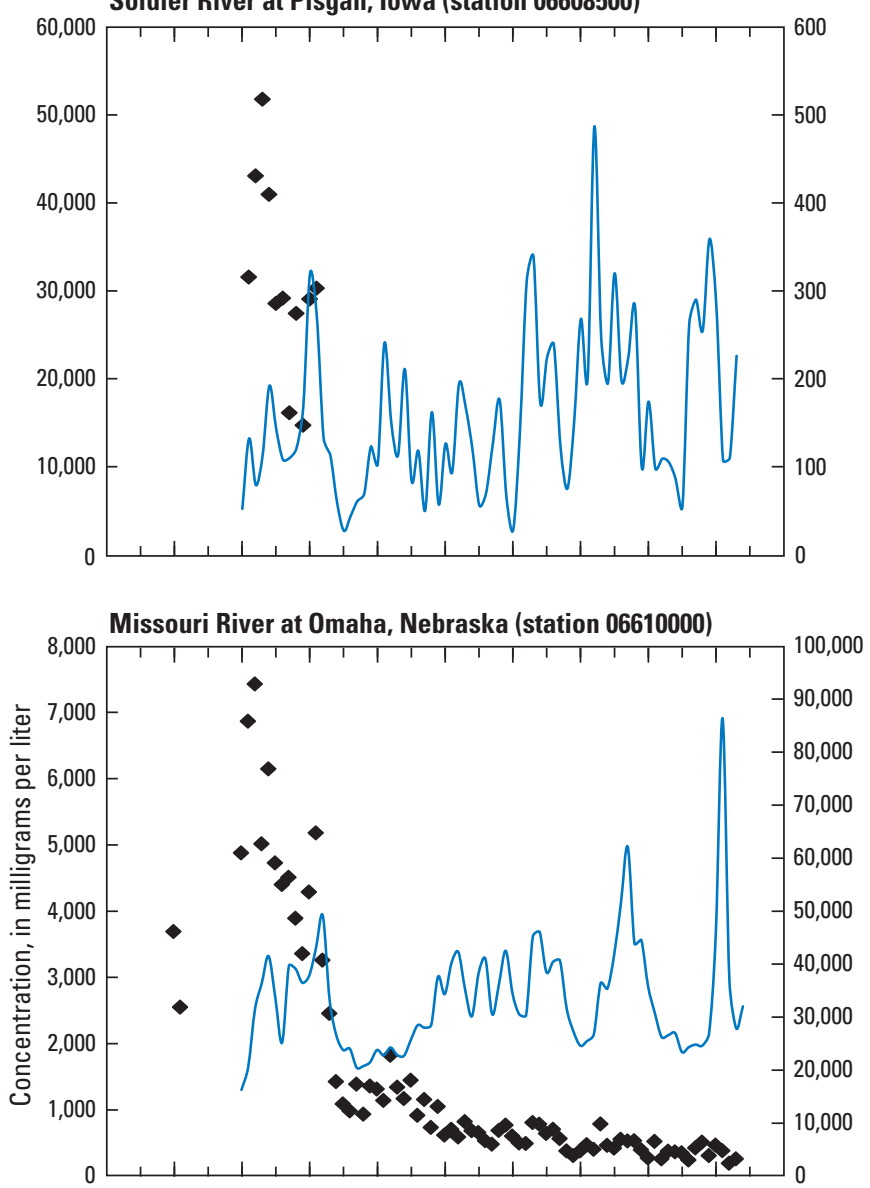

Boyer River at Logan, lowa (station 06609500)
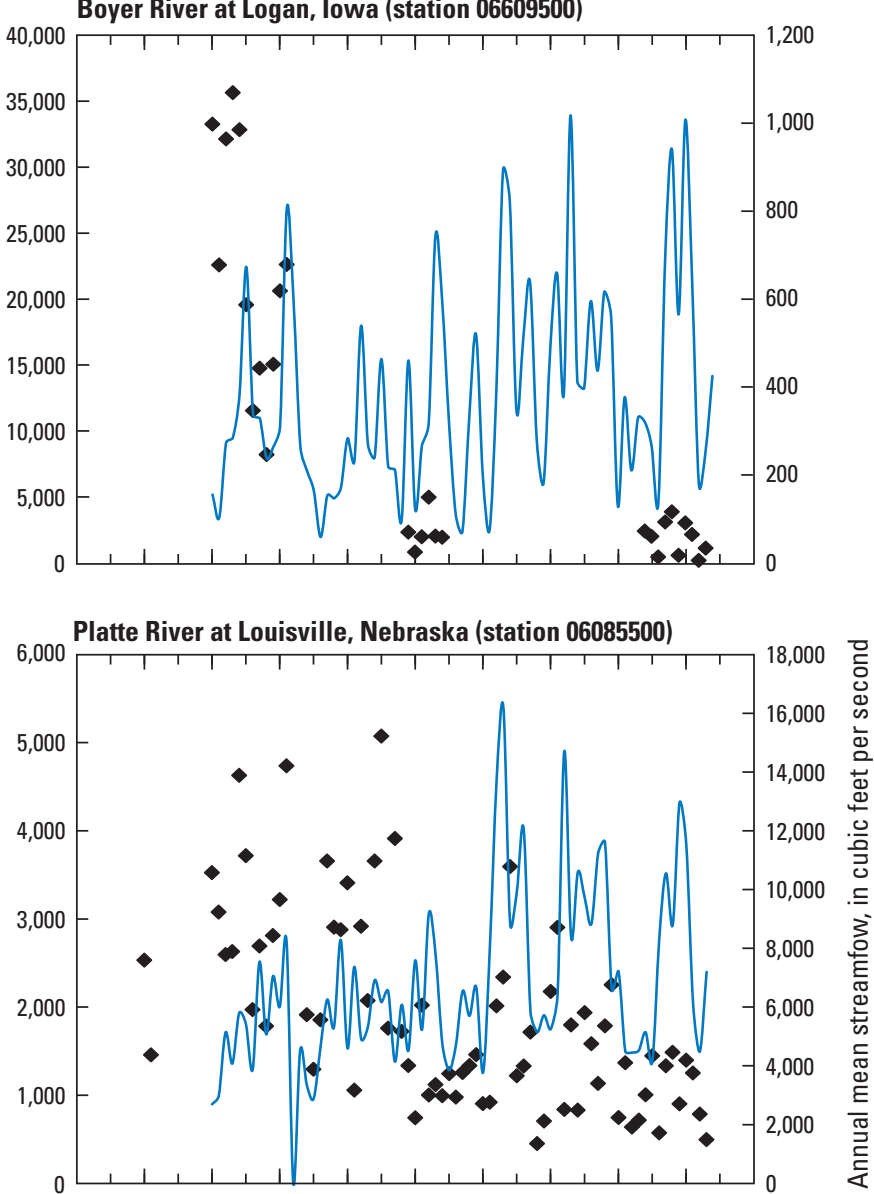
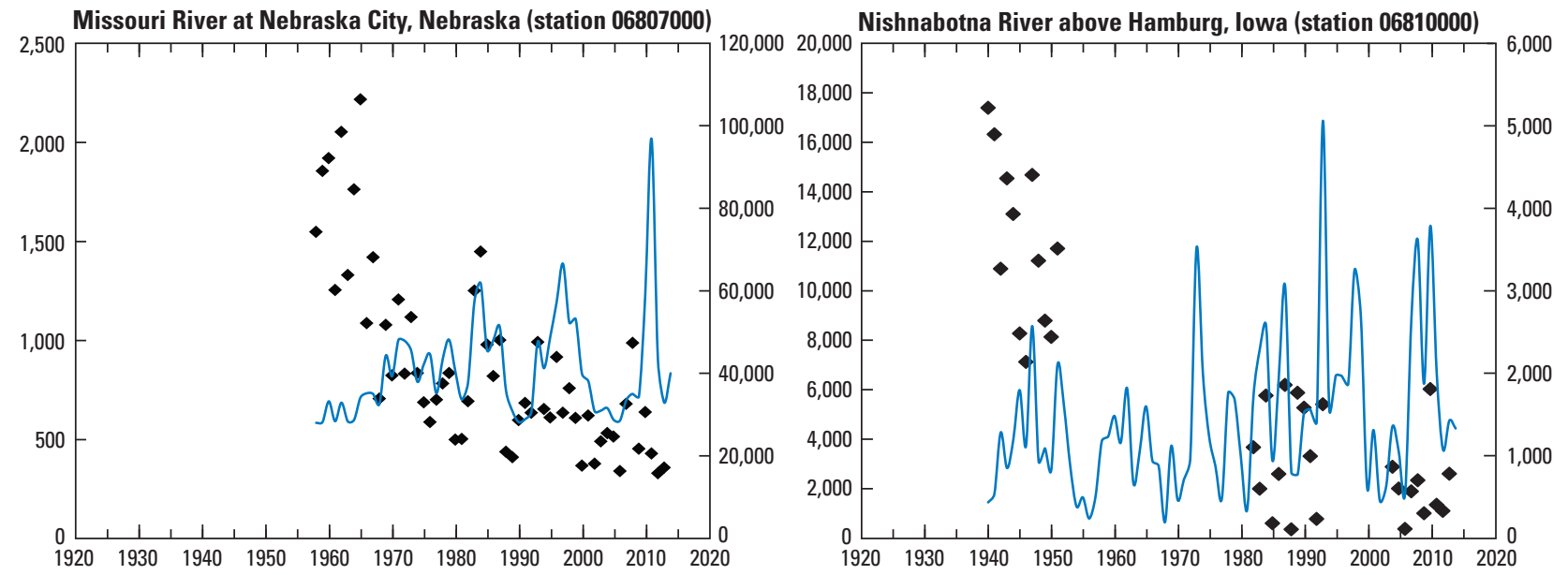
Year

\section{EXPLANATION}

- Annual average streamflow

- Flow-weighted suspended-sediment concentration

Figure 7. Temporal changes in flow-weighted suspended-sediment concentrations at selected stations in the Missouri and Mississippi River Basins, 1930-2014.-Continued 

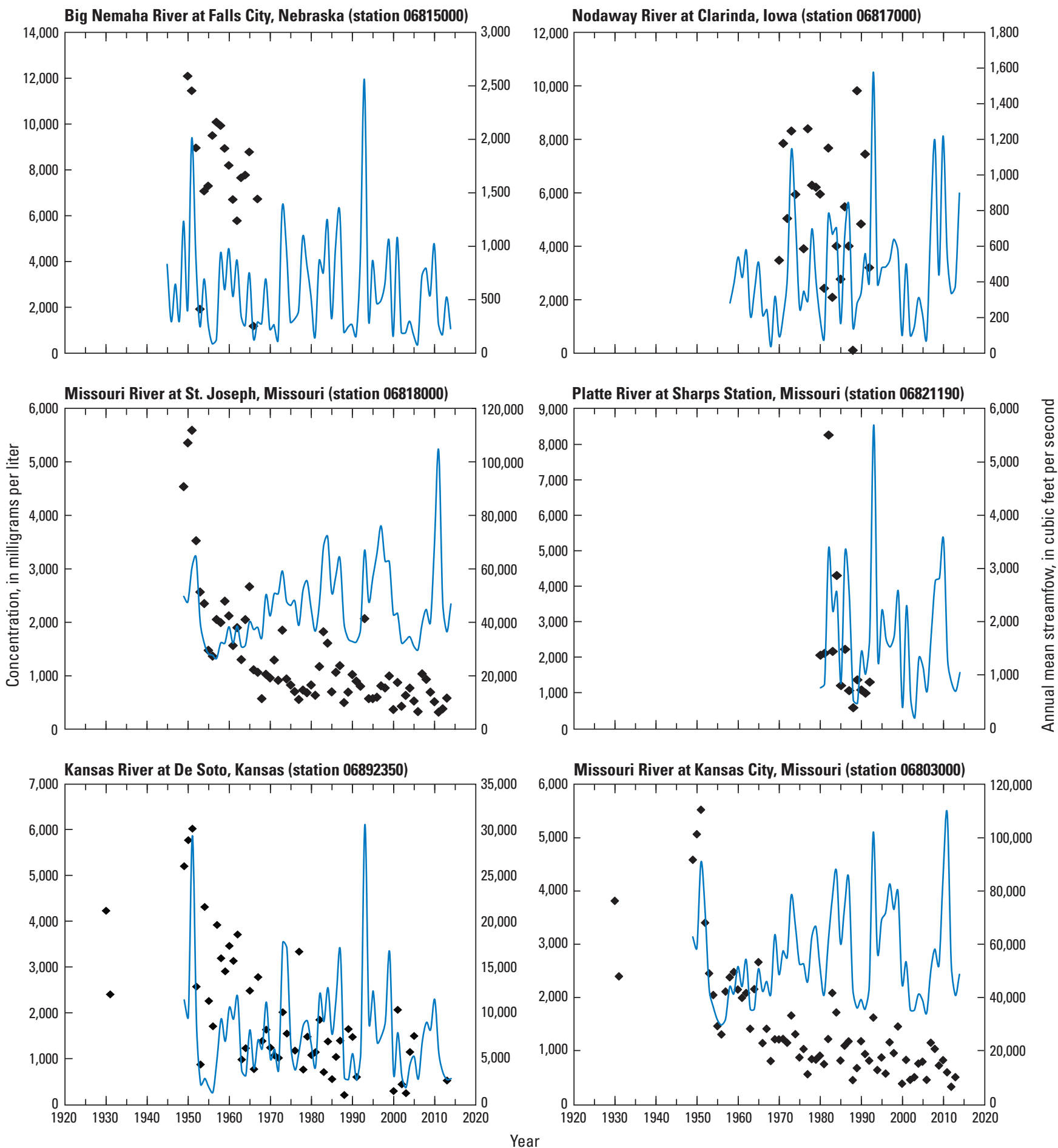

EXPLANATION

- Annual average streamflow

- Flow-weighted suspended-sediment concentration

Figure 7. Temporal changes in flow-weighted suspended-sediment concentrations at selected stations in the Missouri and Mississippi River Basins, 1930-2014.-Continued 
Grand River near Sumner, Missouri (station 06902000)
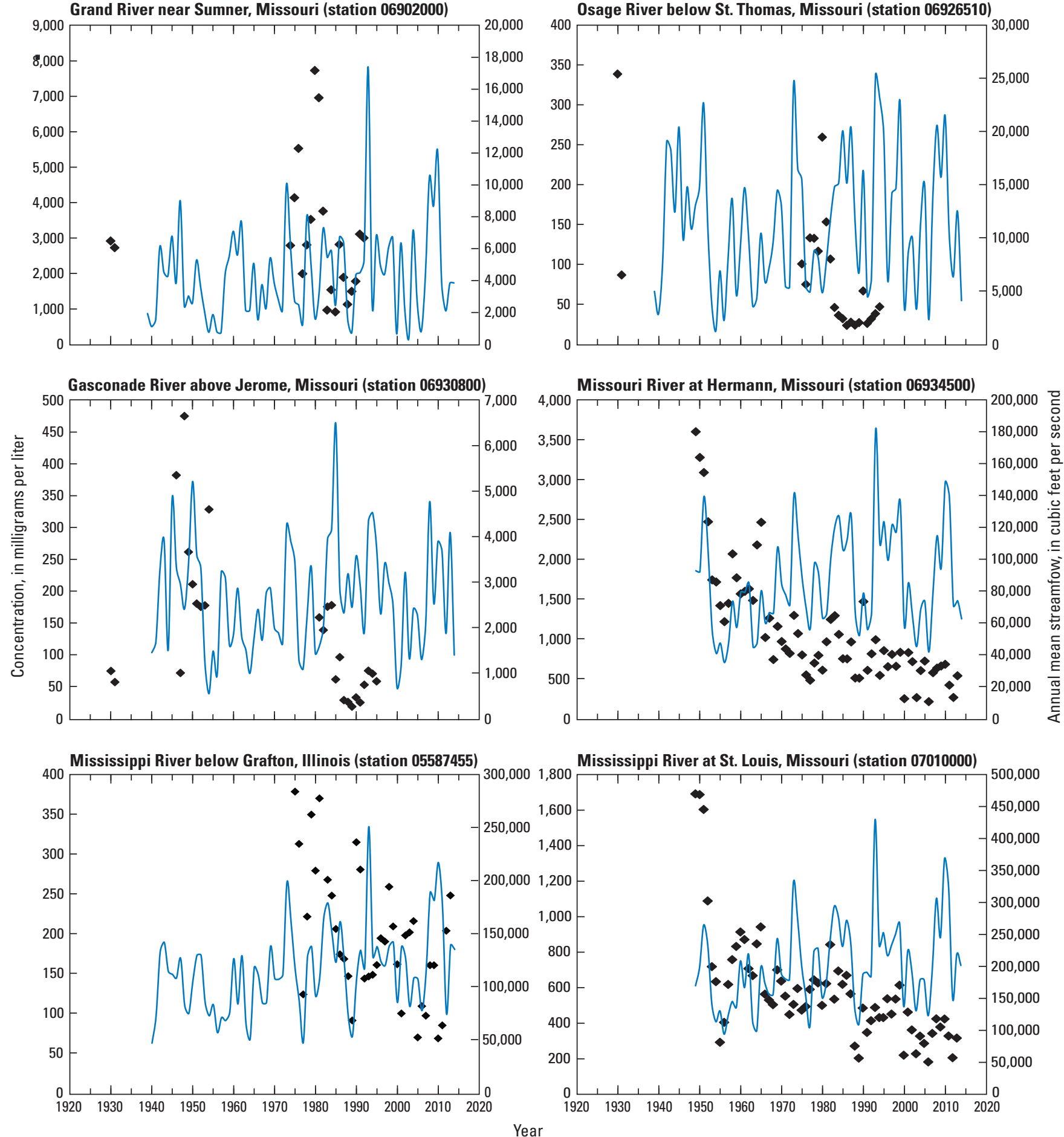

EXPLANATION

Annual average streamflow

- Flow-weighted suspended-sediment concentration

Figure 7. Temporal changes in flow-weighted suspended-sediment concentrations at selected stations in the Missouri and Mississippi River Basins, 1930-2014.-Continued 

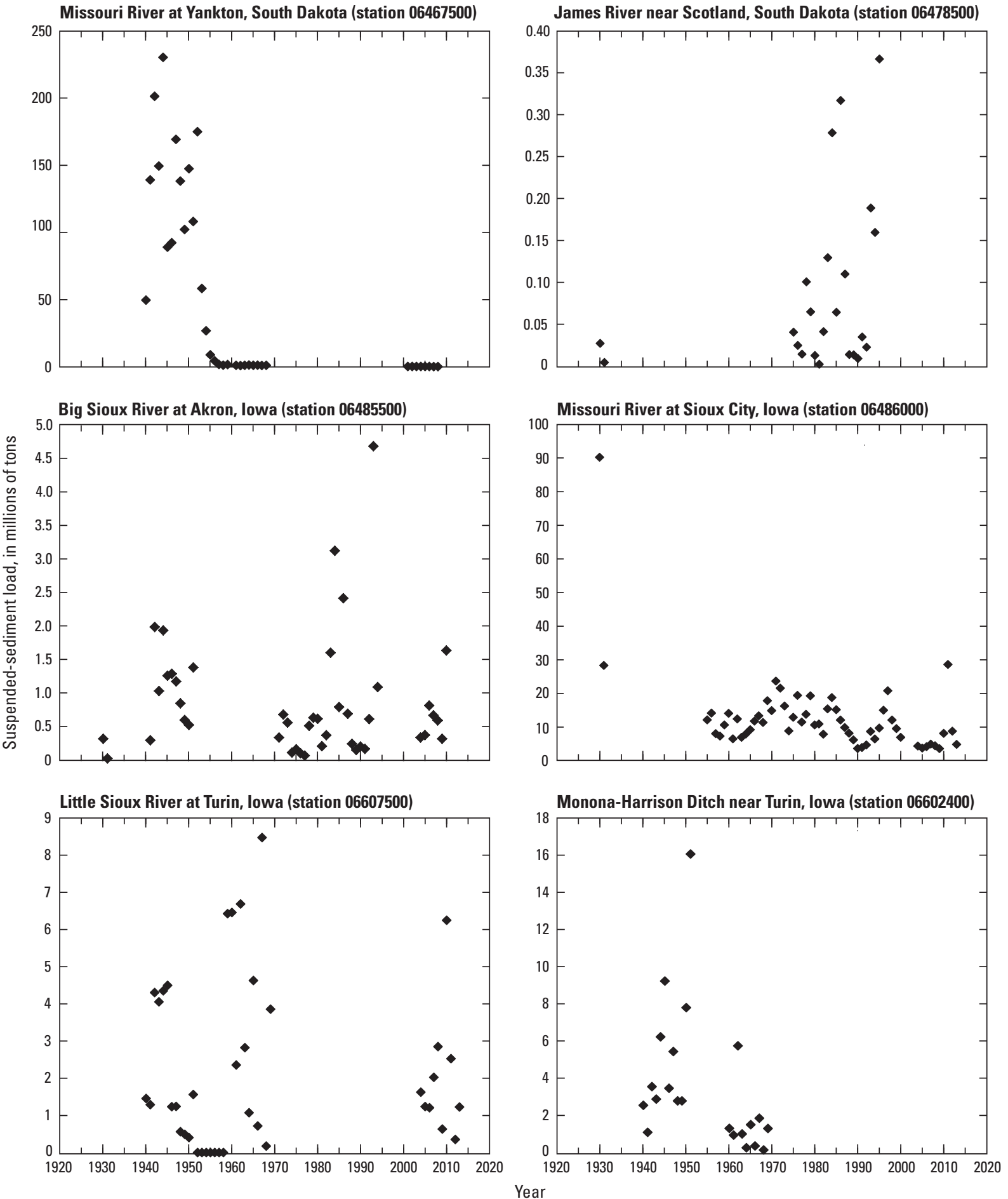

Figure 8. Temporal changes in suspended-sediment loads at selected stations in the Missouri and Mississippi River Basins, 1930-2014.

transport were at stations with insufficient record with which to make a determination and included stations on the James River, Soldier River, Big Nemaha River, Little Nemaha River, Nodaway River, and Platte River (Mo.).

The temporal changes in flow-adjusted SSCs at mainstem M issouri River stations indicated an overall downward change in concentrations between 1968 and 2014 (fig. 9). The decline in flow-adjusted concentrations at upper Lower M issouri River stations (Sioux City, Omaha, and N ebraska City) were greater between 1968 and about 1990 than between 1990 and 2014, and changes in flow-adjusted SSCs for the St. J oseph, K ansas City, and Hermann stations were greater 
Soldier River at Pisgah, lowa (station 06608500)
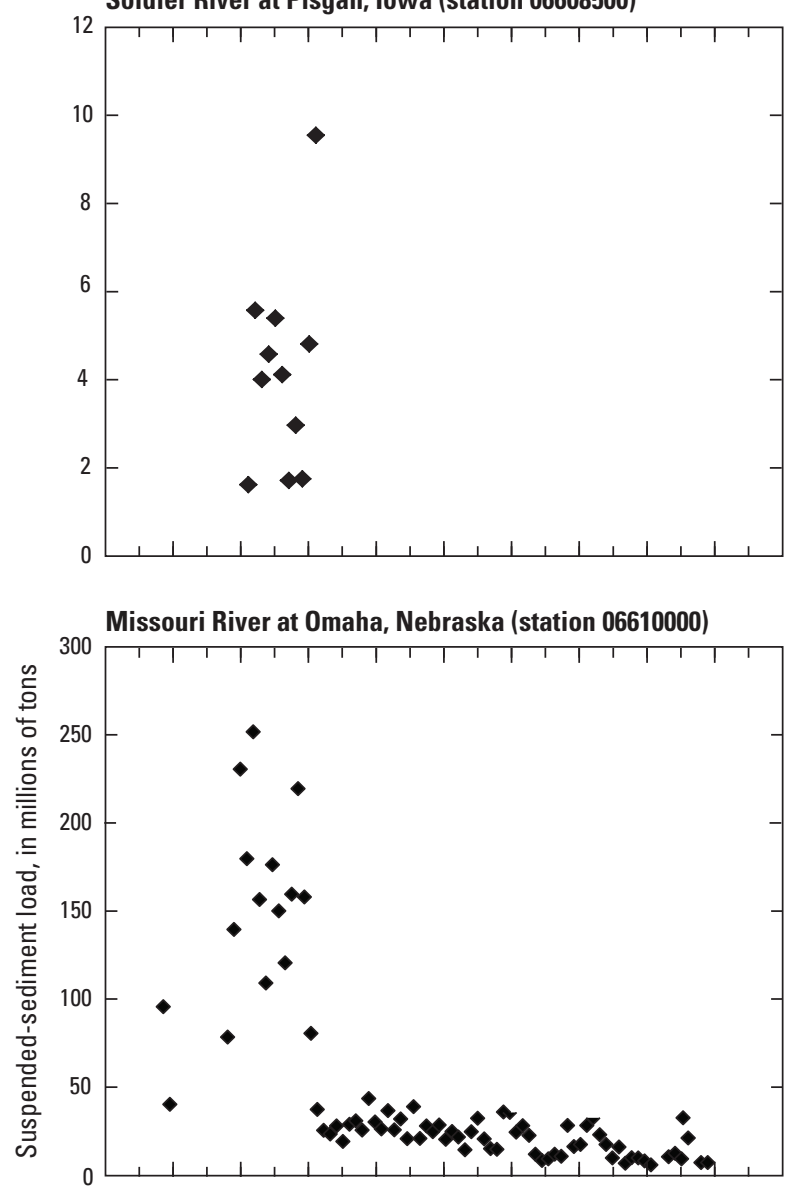

Missouri River at Nebraska City, Nebraska (station 06807000)

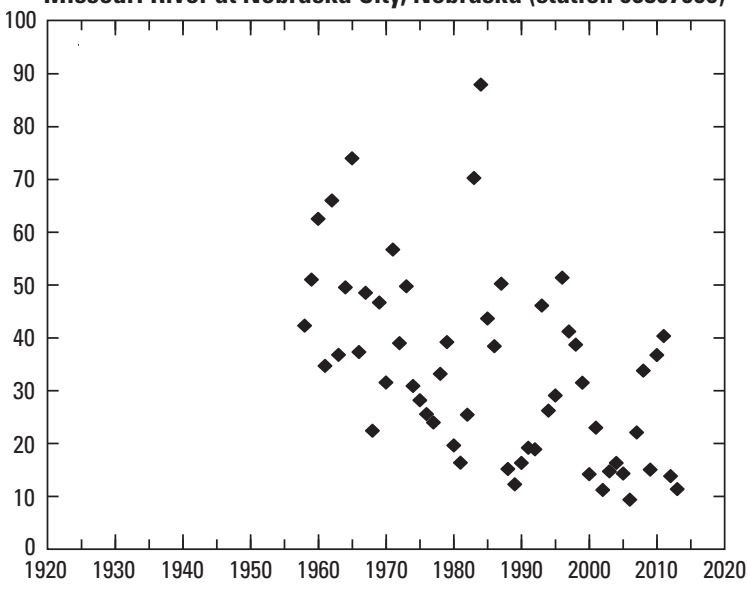

Boyer River at Logan, lowa (station 06609500)

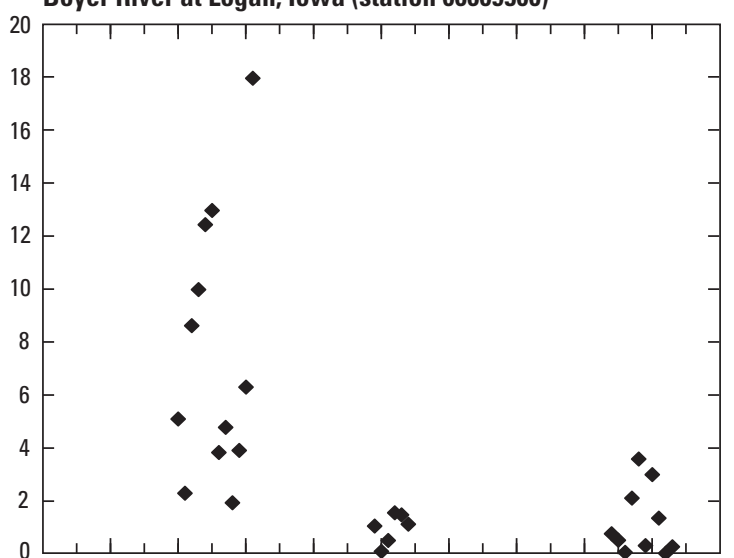

Platte River at Louisville, Nebraska (station 06085500)

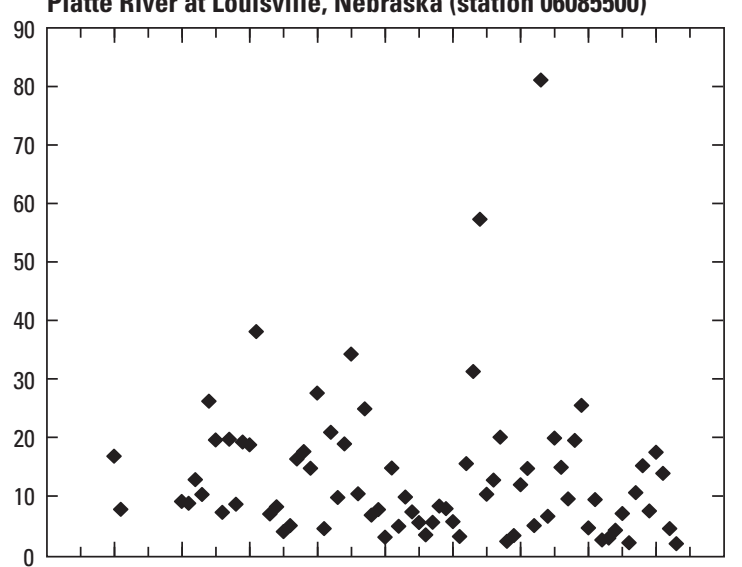

Nishnabotna River above Hamburg, lowa (station 06810000)

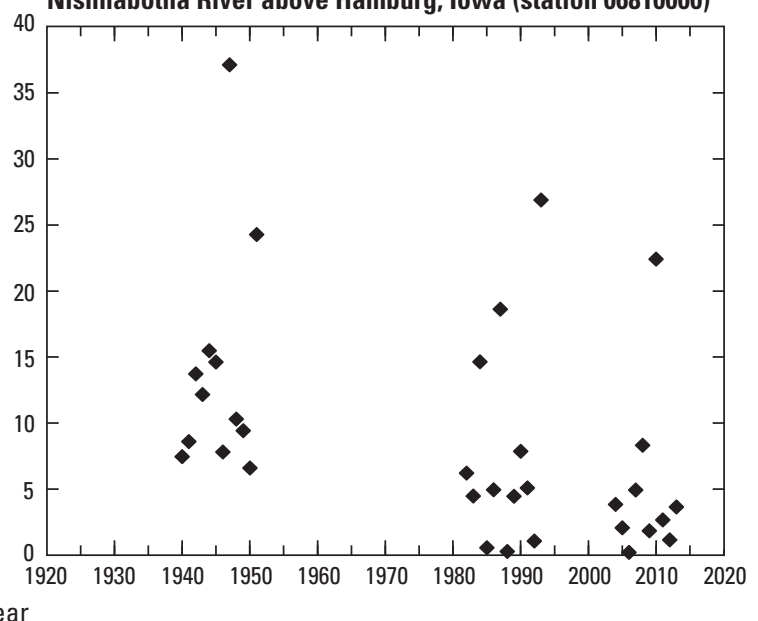

Figure 8. Temporal changes in suspended-sediment loads at selected stations in the Missouri and Mississippi River Basins, 1930-2014.-Continued

between 1990 and 2014 than before 1990. This difference could be an indication of longitudinal differences in the temporal adjustment of the Lower Missouri River to postimpoundment (and other factors affecting sediment supply) conditions in sediment transport. Temporary declines in flowadjusted SSC during and following large floods were evident (most notably during 2010-11 at all stations and during 1993 at the Hermann station) but appeared to be short-lived. The SSC residuals in the sediment transport relation generally returned to near pre-flood values within about 6 months. 

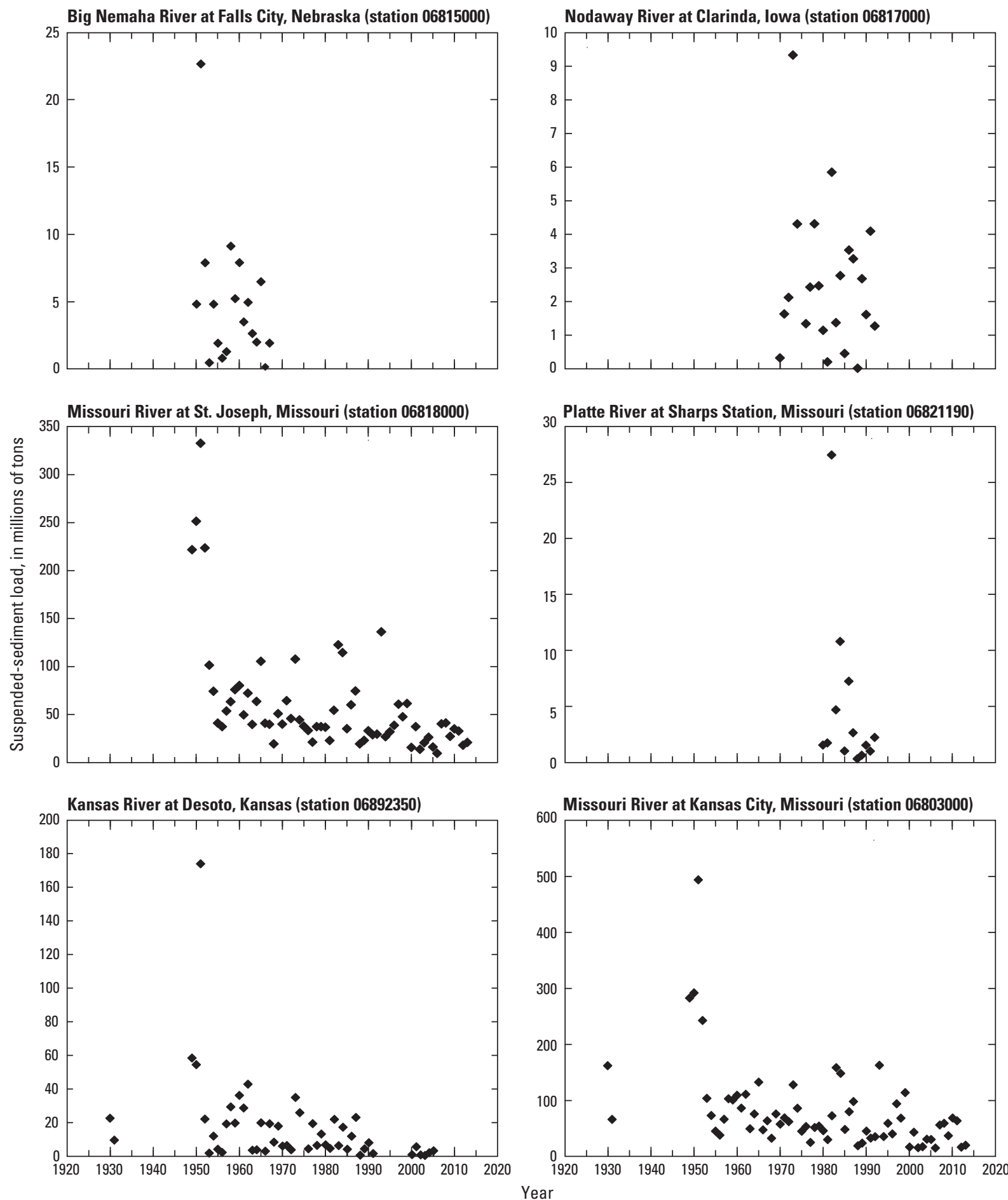

Figure 8. Temporal changes in suspended-sediment loads at selected stations in the Missouri and Mississippi River Basins, 1930-2014.-Continued

\section{Long-Term, 1968-2014 Sediment Budget}

A generalized long-term sediment budget was determined for the post-impoundment period (1968-2014) using the available record as a best estimate of the long-term average suspended-sediment transport (table 8; fig. 10). Long-term average annual SSLs among the M issouri River main-stem stations ranged from 0.33 million tons at the Yankton station to 71.2 million tons at the Hermann station. Gaged tributary gains accounted for 9-36 percent of the local reach budgets, and cumulative gaged tributary contributions accounted for 84 percent of the long-term average SSL at the Hermann station. A lthough the budgets generally were incomplete and missing bedload, channel and flood-plain storage, and ungaged 

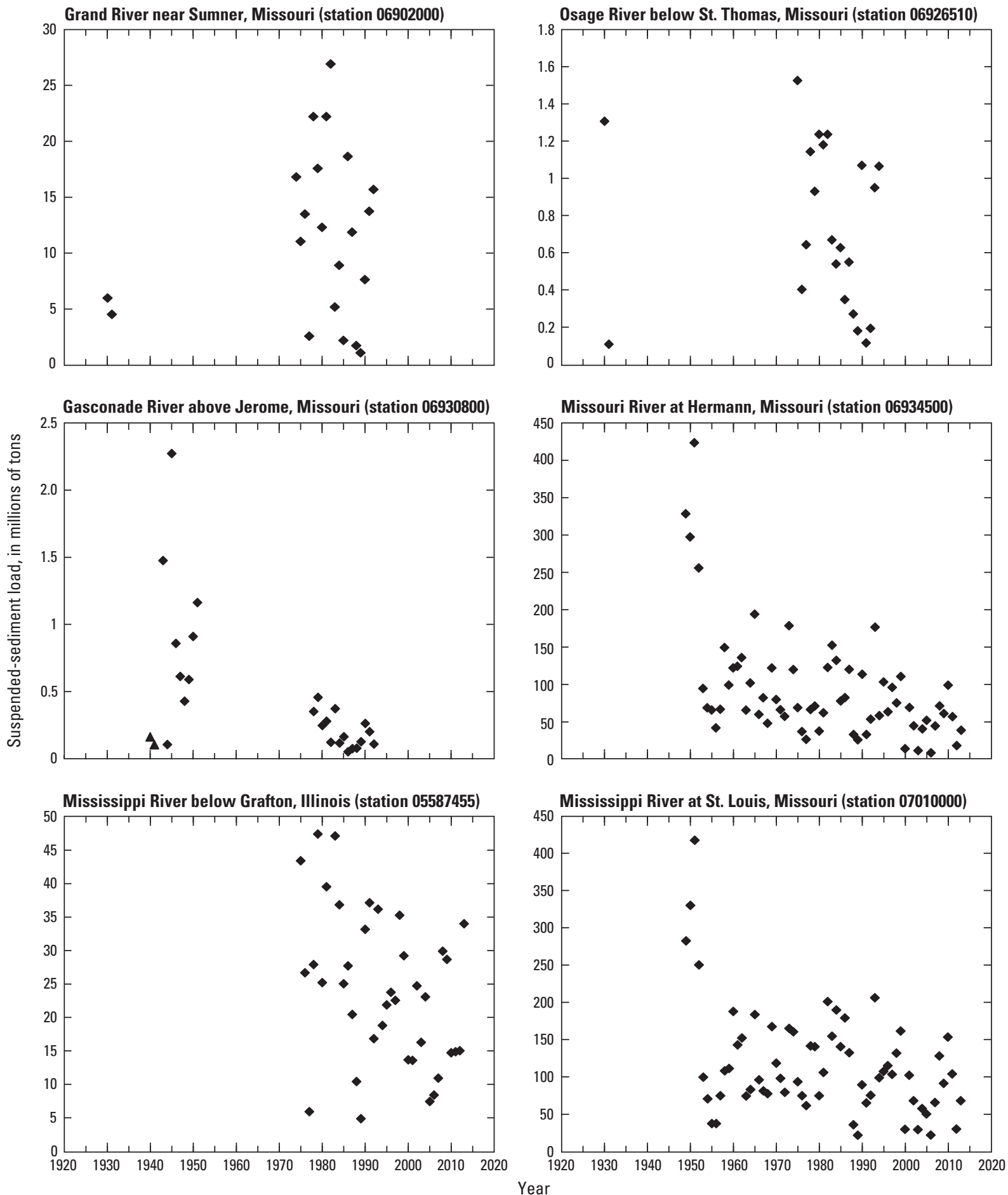

Figure 8. Temporal changes in suspended-sediment loads at selected stations in the Missouri and Mississippi River Basins, 1930-2014.-Continued

tributary contributions, the budget residuals for six of the seven reaches ranged from -7.0 to 1.7 million tons, or from -9.2 to 4.0 percent of the reach output SSL, and were within the 10 percent reported measurement error of annual SSLs for large rivers (Colby, 1956; Holmes, 1996). The remaining reach, Yankton, S. Dak., to Sioux City, Iowa, had an average budget residual of -9.8 million tons per year, (-88 percent of the reach output $S S L$ ), indicating the input $S S L$ and reach gains from gaged tributaries accounted for a small part of output SSL. A reach-by-reach description of the long-term sediment budget is provided in the following sections. 


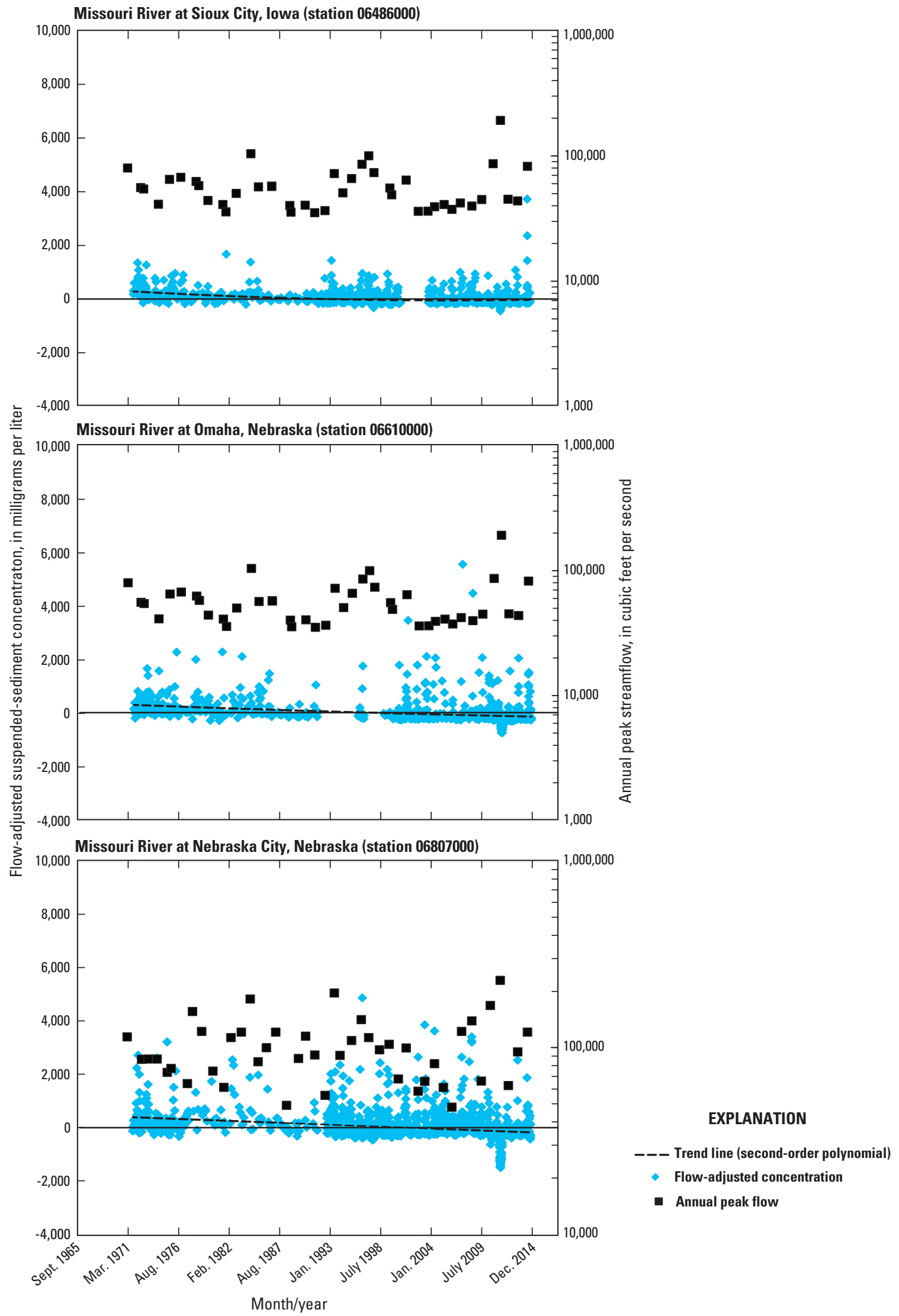

Figure 9. Temporal changes in flow-adjusted suspended-sediment concentrations at main-stem Lower Missouri River stations, 1968-2014. 


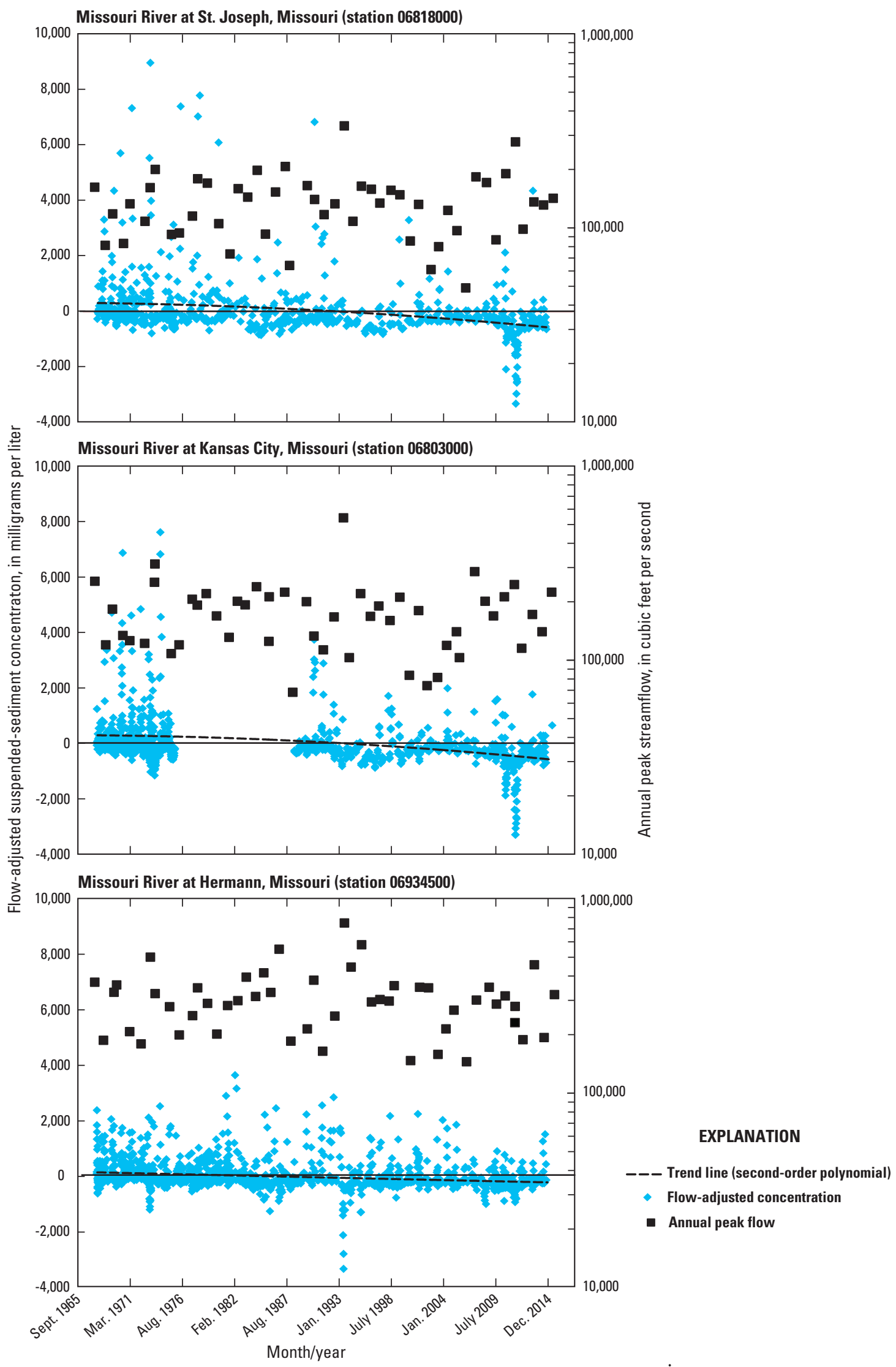

Figure 9. Temporal changes in flow-adjusted suspended-sediment concentrations at main-stem Lower Missouri River stations, 1968-2014.-Continued 


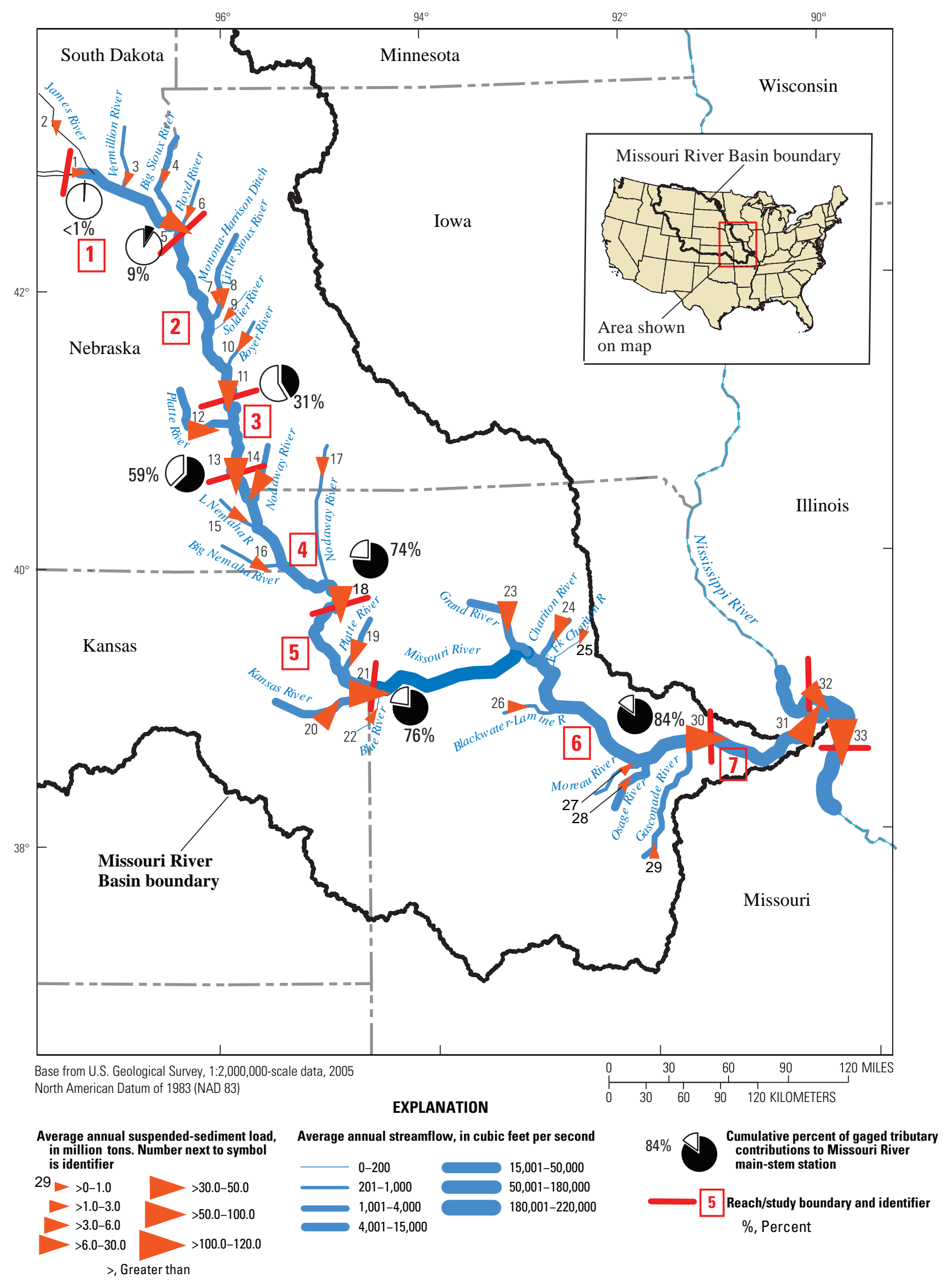

Figure 10. Generalized suspended-sediment budget of the Lower Missouri River, 1968-2014. 


\section{Reach 1-Missouri River at Yankton, S. Dak., to Sioux City, lowa}

The 79-mile reach from Yankton to Sioux City had the largest average budget residual of any of the seven reaches at -9.8 million tons per year, accounting for 88.0 percent of the 1968-2014 average annual SSL at the Sioux City station (11.2 million tons; table 8). The measured tributary SSL inputs in this reach in total averaged about 1.0 million tons per year, and the 9.8 million tons per year residual generally could be accounted for by storage losses from bank and channelbed scour. The largest measured gain in this reach was from the Big Sioux River at A kron, lowa, station with an average SSL of about 0.80 million tons per year (fig. 11). Cumulative measured tributary inputs upstream from the Sioux City station account for 9.3 percent of the average annual SSL at the Sioux City station. The ungagged local contributing drainage accounts for about 15 percent of the local reach drainage area. No annual bedload data were available for this reach nor were any quantified changes in storage from commercial dredging or MRRP activities.

The M issouri River within the Yankton to Sioux City reach has degraded in response to the sediment-free discharge from Gavins Point Dam (U.S. A rmy Corps of Engineers, 2012). Streambed degradation downstream from dams is a widely documented fluvial adjustment of the coarse sediment supply to the carrying capacity of the river. The 1968-2011 stage trends downstream from Gavins Point Dam and at the Sioux City station were downward and directly correlated with the substantial suspended-sediment budget deficit determined for this reach. During the budget period, the stage trend at the tailwaters of Gavins Point Dam indicated a decline of about 12 feet (ft; U.S. Army Corps of Engineers, 2012) for a flow of 20,000 cubic feet per second $\left(\mathrm{ft}^{3} / \mathrm{s}\right)$; however, the average flow at the Yankton station was 26,000 $\mathrm{ft}^{3} / \mathrm{s}$. B etween 1968 and 2011, the stage at the Sioux City station declined $12 \mathrm{ft}$ for a flow of 30,000 $\mathrm{ft}^{3} / \mathrm{s}$ (U.S. A rmy Corps of Engineers, 2012); a flow comparable to the average 1968-2014 flow at the Sioux City station of $32,000 \mathrm{ft}^{3} / \mathrm{s}$. The declining stage trend was consistent among the range of flows at the Sioux City station. A substantial part of the stage declines at the Yankton and Sioux City stations was during high-flow (1995-1998 and 2011). Geomorphological analyses of the approximately 60 miles of the M issouri River downstream from Gavins Point Dam (Pokrefke and others, 1998; B iedenharn and others, 2001; Elliot and J acobson, 2006) indicated that channel-bank erosion is a substantial source of transported sediment and perhaps a larger source of transported material than bed scour, at least in some reaches and measurement periods.

\section{Reach 2-Missouri River at Sioux City, lowa, to Omaha, Nebr.}

The residual of the sediment budget for the 116-mile reach from Sioux City to Omaha is a long-term average deficit of about 1.7 million tons per year (table 8 ). The residual of -1.7 million tons is -9.2 percent of the average annual SSL of 18.9 million tons at the Omaha station and within the reported 10 percent accuracy of annual SSL s (Holmes, 1996). Cumulative tributary inputs in the Sioux City to 0 maha reach account for 30.6 percent of the long-term average annual SSL of the main stem at the 0 maha station, al though sediment contributions from about 20 percent of the local drainage area were unmeasured. The largest sediment gain in the reach was from the Little Sioux River at Turin, lowa, station with an estimated SSL of 1.9 million tons per year (fig. 12).

No corresponding long-term information on bedload transport was available for the Sioux City to O maha reach. The average annual M RRP-associated gain for this reach was about 0.20 million tons (table 8). The corresponding stage trends for the main stem at the O maha station for 1968-2014 indicated a change of $-1 \mathrm{ft}$ for a flow of $10,000 \mathrm{ft}^{3} / \mathrm{s}$ to $-4 \mathrm{ft}$ for a flow of 40,000 $\mathrm{ft}^{3} / \mathrm{s}$ (U.S. A rmy Corps of Engineers, 2012), and the average 1968-2014 flow was $36,000 \mathrm{ft}^{3} / \mathrm{s}$. A substantial part of the stage decline at the O maha station at average and lower flows can be attributed to flooding in 2011; and, since 2011stages have rebounded in this reach (Dan Pridal, U.S A rmy Corps of Engineers, written commun., 2016). Increasing stages of about $2 \mathrm{ft}$ at constant higher flows $\left(100,000 \mathrm{ft}^{3} / \mathrm{s}\right)$ possibly indicate aggrading conditions from bank and flood-plain storage during the same period; however, the increases in stages also could be an indication of levee construction or modifications.

\section{Reach 3-Missouri River at Omaha, Nebr., to Nebraska City, Nebr.}

The reach from $\mathrm{O}$ maha to $\mathrm{N}$ ebraska City is the shortest (53 miles) and "simplest" main-stem reach; the reach only has one primary tributary (Platte River). The long-term sediment budget residual was -0.5 million tons or -1.7 percent of the SSL at the N ebraska City station (table 8). Tributary contributions were 11.1 million tons per year or 36.8 percent of SSL S at the Nebraska City station. Downstream from the confluence with the Platte River and beyond, the cumulative tributary inputs to the M issouri River account for most (in this reach 59.4 percent of the SSL at the Nebraska City station) of the sediment sources in the L ower M issouri River. A lthough the Platte River is the only major tributary in this reach, it generally was the largest tributary supplier of sediment to the L ower $M$ issouri River. The average annual load at the Platte River at L ouisville, N ebr., station was about 11.1 million tons (table 8; fig. 13). The Platte River drainage area also accounts for about 98 percent of the local reach drainage area.

The average annual bedload input in the reach was unknown, but the estimated average output was 0.45 million tons. The average M R RP additions were about 0.14 million tons per year, and commercial dredging did not take place 


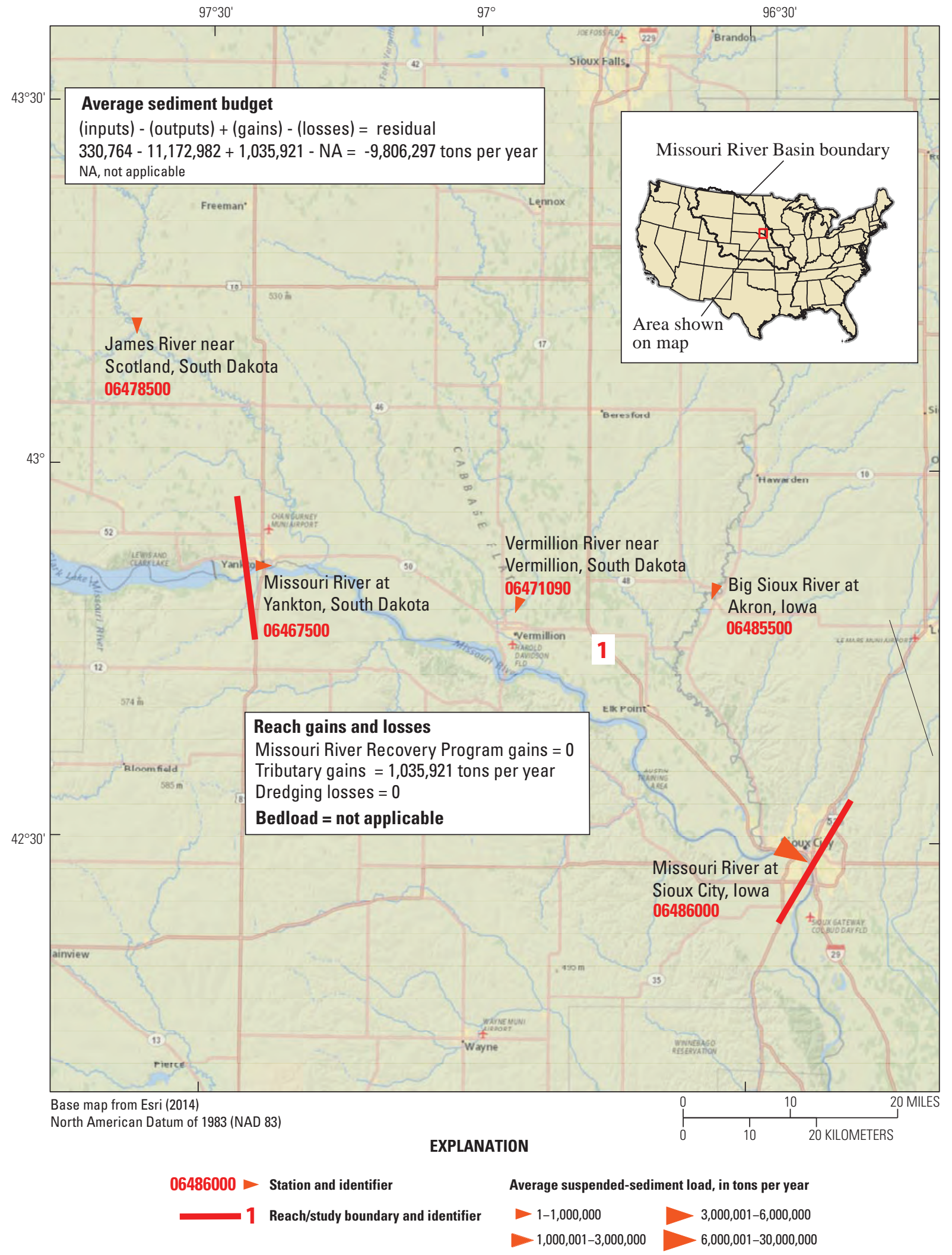

Figure 11. Long-term average sediment budget, Lower Missouri River reach 1, Yankton, South Dakota, to Sioux City, lowa, 1968-2014. 


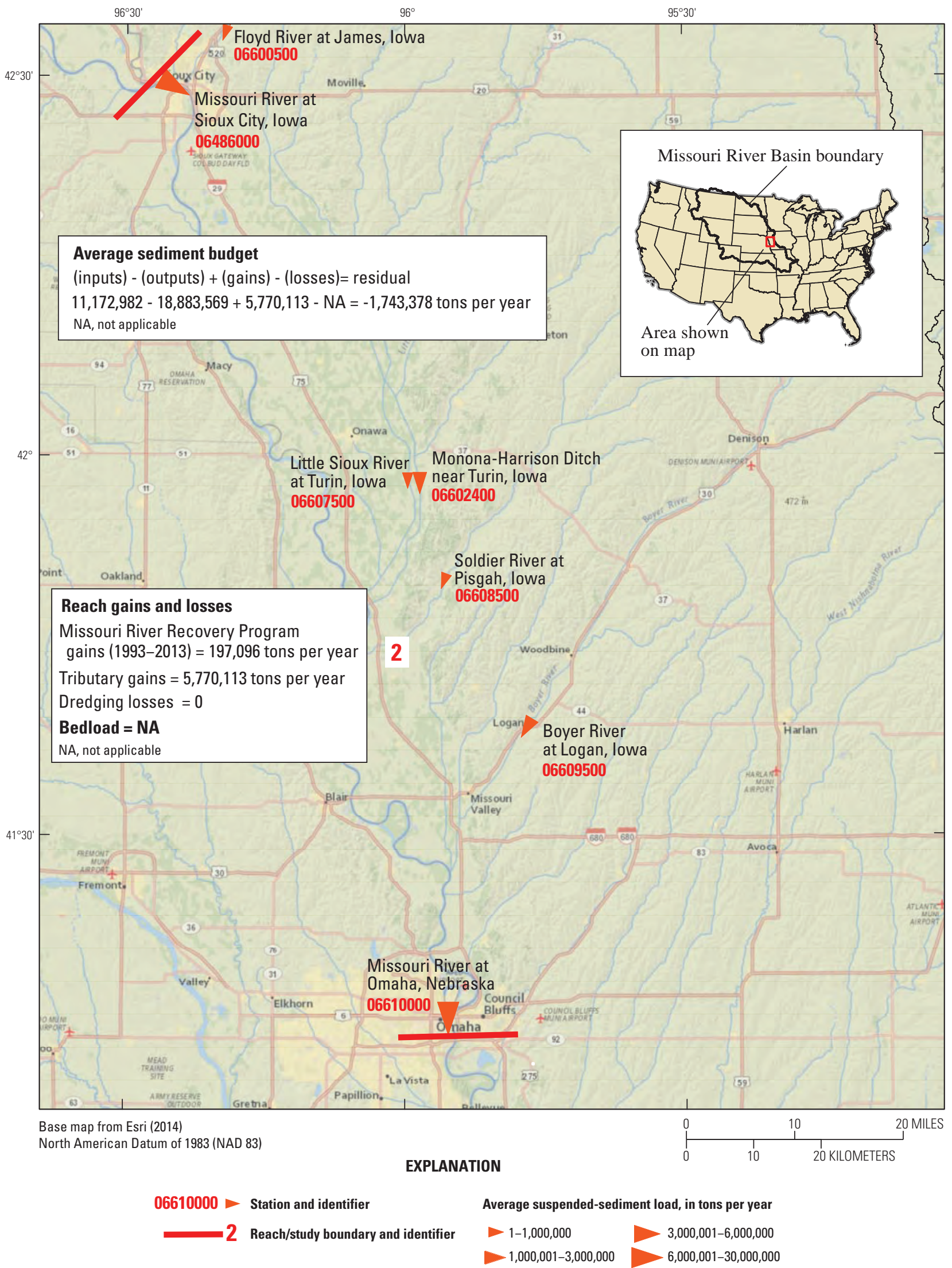

Figure 12. Long-term average sediment budget, Lower Missouri River reach 2, Sioux City, lowa, to Omaha, Nebraska, 1968-2014. 

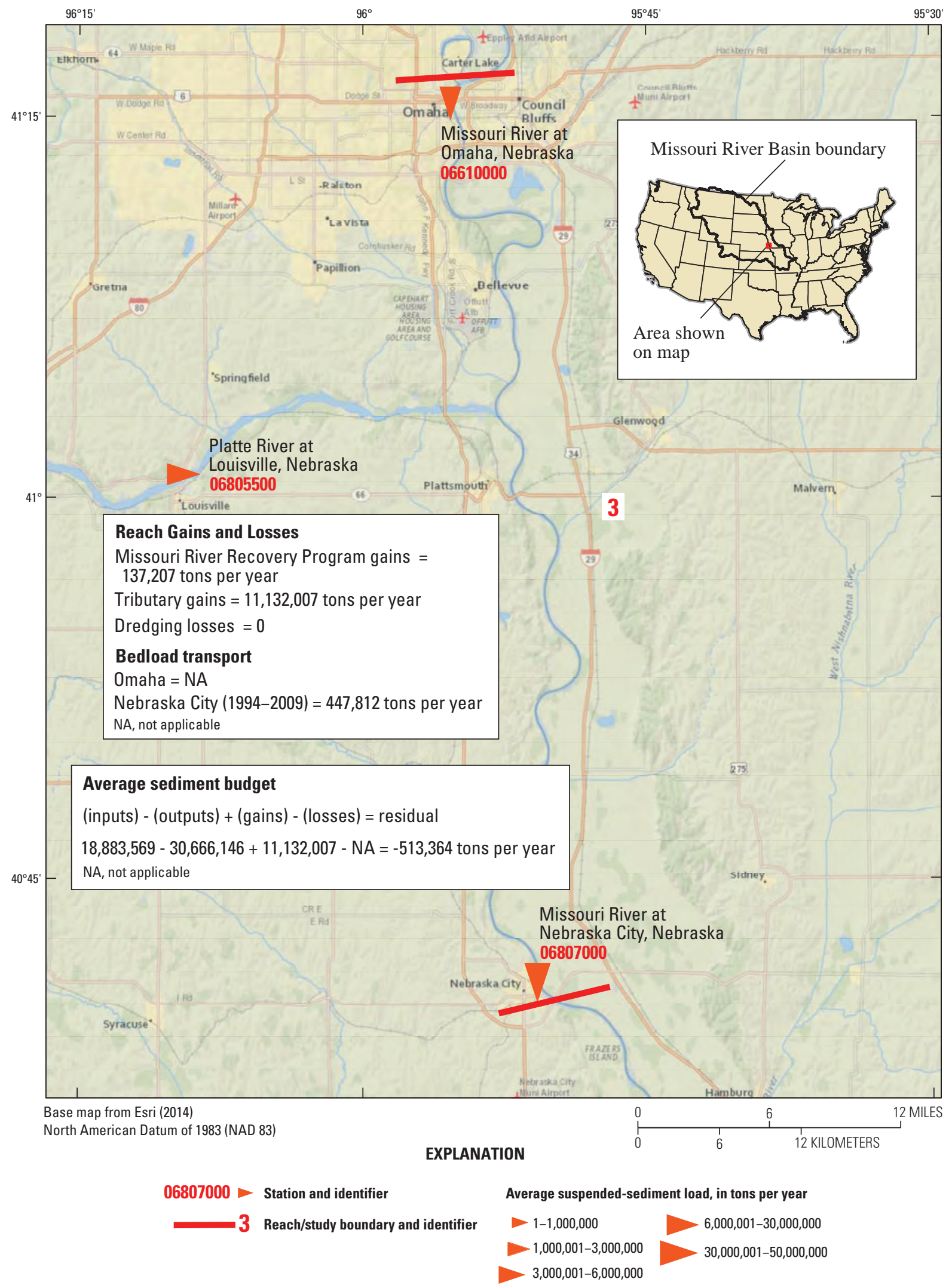

Figure 13. Long-term average sediment budget, Lower Missouri River reach 3, Omaha, Nebraska, to Nebraska City, Nebraska, 1968-2014. 
in the reach. The net stage change during 1968-2011 for the reach was small and near $1 \mathrm{ft}$ for a flow of $40,000 \mathrm{ft}^{3} / \mathrm{s}$ (U.S. Army Corps of Engineers, 2012), and the average streamflow of the main stem at the N ebraska City station was $42,600 \mathrm{ft}^{3} / \mathrm{s}$ for the post-impoundment period. Stages for higher streamflows (70,000-180,000 fts) indicated possible bank and flood-plain aggradation because stages increased about $2 \mathrm{ft}$ during the same period.

\section{Reach 4-Missouri River at Nebraska City, Nebr., to St. Joseph, Mo.}

During 1968-2014, the net average suspended-sediment budget residual in the 114-mile reach from N ebraska City to St. J oseph was 1.7 million tons per year or 4.0 percent of the average annual load for the St. Joseph station (42.3 million tons; table 8). The local contribution from tributaries in this reach was 13.5 million tons per year or 31.7 percent of the SSL at the St. Joseph station, and cumulative contributions from tributaries accounted for 74.3 percent of the SSL at the St. J oseph station. The largest contributing tributary in this reach was the $\mathrm{N}$ ishnabotna River. The average SSL was 6.4 million tons per year for the Nishnabotna River above Hamburg, Iowa, station (fig. 14). The SSLs at the Little N emaha River at A uburn N ebr., station (1.6 million tons per year; fig. 14) and Big Nemaha River at Falls City, Nebr., station (2.9 million tons per year; fig. 14) have greater uncertainty (possibly 100 percent) compared to other tributary gains in the reach because these tributary SSL $s$ were estimated. The gaged tributaries account for only 35 percent of the local reach drainage area and, therefore, the additional 65 percent of unmeasured sediment contributions could be substantial and add to the al ready positive budget residual .

The 1994-2009 average annual theoretical bedload transport at the N ebraska City station was 0.45 million tons per year and at the St. J oseph station was 0.34 million tons per year, based on theoretical ratings developed using data from ENTRIX, Inc. (2011). The difference in the 1994-2009 average annual theoretical bedload estimates for the N ebraska City to St. Joseph reach was +0.10 million tons per year and was used as the estimated net bedload transport in the 1968-2014 budget for this reach (table 8). During 1968-2014, the average total dredging loss was 0.09 million tons per year, and the estimated average annual total M RRP gain was 0.30 million tons. The stage trend for the St. J oseph station indicated net degrading conditions for 1968-2011 that ranged from -3.5 ft for a flow of $40,000 \mathrm{ft}^{3} / \mathrm{s}$ to $-1.5 \mathrm{ft}$ for a flow of $70,000 \mathrm{ft}^{3} / \mathrm{s}$ (U.S. A rmy Corps of Engineers, 2012). During the analysis period, the average annual flow for the St. Joseph station was $49,000 \mathrm{ft}^{3} / \mathrm{s}$. Stages for constant flows greater than 100,000 $\mathrm{ft}^{3} / \mathrm{s}$ indicated increasing stage trends and possible aggrading conditions of about 2-3 ft. The sediment budget for this reach was more complete than that of most Missouri River reaches, and the difference between the positive total budget residual and the negative stage trend indicated that data gaps and uncertainties limit the determination of aggrading or degrading conditions based on budget residuals alone.

\section{Reach 5-Missouri River at St. Joseph, Mo., to Kansas City, Mo.}

The net suspended-sediment budget residual in the 82-mile reach from $\mathrm{St}$. J oseph to $\mathrm{K}$ ansas $\mathrm{C}$ ity was -2.8 million tons or -4.9 percent of the average 57.2 million tons per year total sediment load at the $\mathrm{K}$ ansas City station (table 8). Tributaries accounted for 11.7 million tons or 20.6 percent of average reach outputs, and cumulative gaged tributary contributions accounted for 76.1 percent of the long-term average annual SSL at the $\mathrm{K}$ ansas City station. The largest tributary in this reach was the $\mathrm{K}$ ansas River. The average annual SSL at the $K$ ansas River at De Soto, $K$ ans., station was 8.8 million tons (fig. 15). Sediment contributions from the ungaged local reach drainage area should not be a substantial gain because the local ungaged drainage area was within the error of the basin area determination.

For 1994-2009, the average annual theoretical bedload transport at the $\mathrm{St}$. J oseph station was 0.34 million tons and at the $\mathrm{K}$ ansas $\mathrm{City}$ station was 0.47 million tons using data from ENTRIX, Inc. (2011). The difference in the 1994-2009 theoretical bedload estimates for the St. J oseph to K ansas City reach was -0.13 million tons per year and was used as the bedload estimate in the 1968-2014 budget (table 8). The average annual total dredging loss in the reach for 1968-2014 was about 0.7 million tons per year, and the average annual total M RRP contribution was about 0.68 million tons per year. Stage trends during 1968-2011 for the K ansas City station also indicated degrading conditions that were $-7 \mathrm{ft}$ for a flow of $40,000 \mathrm{ft}^{3} / \mathrm{s}$ and $-6 \mathrm{ft}$ for a flow of $70,000 \mathrm{ft}^{3} / \mathrm{s}$ (U.S. A rmy Corps of Engineers, 2012), and the average 1968-2014 annual flow at the Kansas City station was $58,500 \mathrm{ft}^{3} / \mathrm{s}$. The decline in stage trends was consistent for all reported flows.

\section{Reach 6-Missouri River at Kansas City, Mo., to Hermann, Mo.}

The reach from $\mathrm{K}$ ansas City to Hermann is the longest main-stem study reach (268 miles) and included eight major gaged tributaries in the reach budget. The average suspendedsediment budget residual for 1968-2014 was 0.07 million tons per year or 0.1 percent of the total sediment load of 71.7 million tons at the Hermann station (table 8). The largest sediment gain in the reach was at the Grand River near Sumner, M o., station with an average SSL of 9.8 million tons, and the second largest sediment gain in the reach was at the Chariton River near Prai rie Hill, M 0., station with an average annual SSL of about 3.6 million tons per year (fig. 16). 


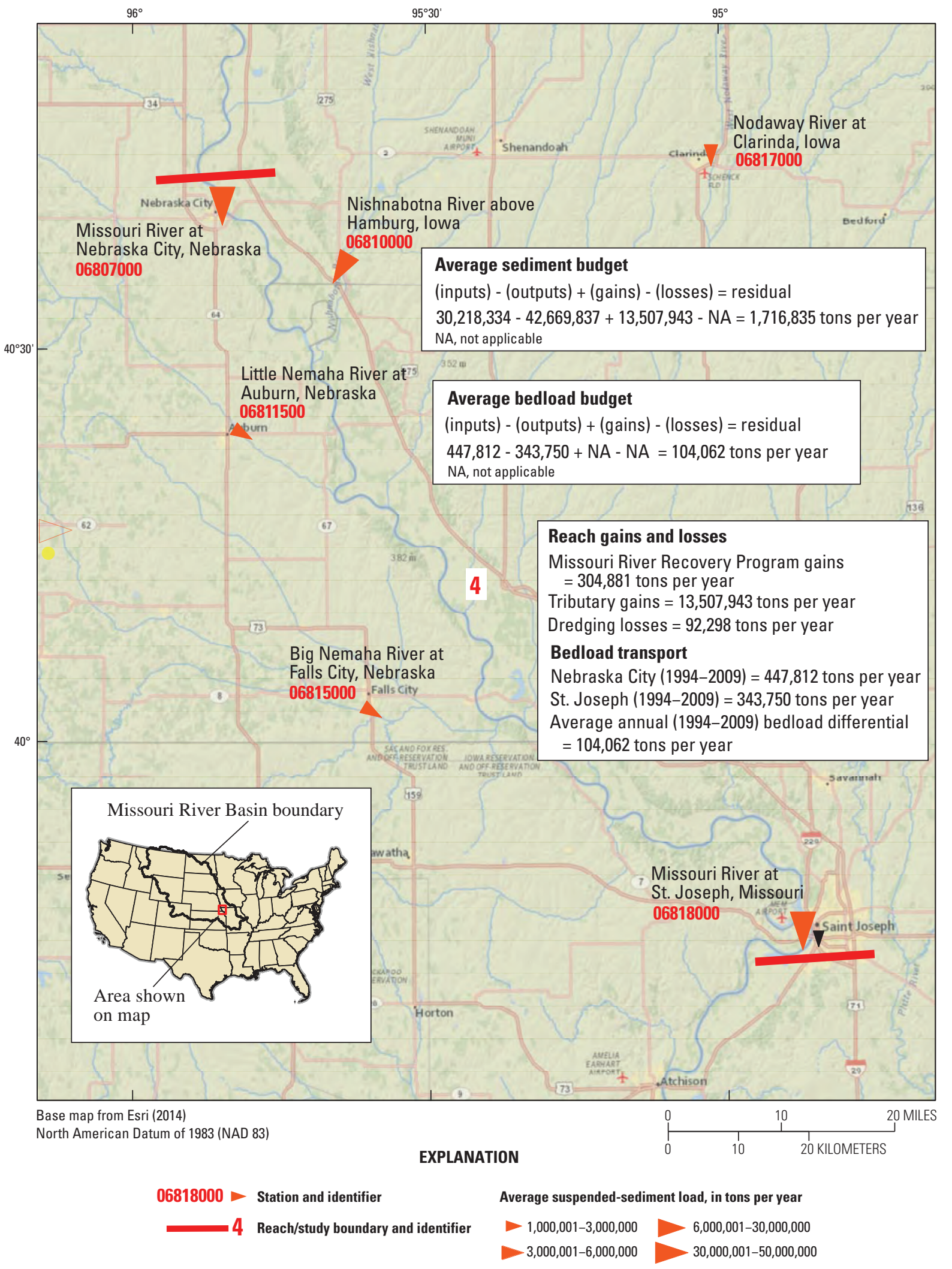

Figure 14. Long-term average sediment budget, Lower Missouri River reach 4, Nebraska City, Nebraska, to St. Joseph, Missouri, 1968-2014. 


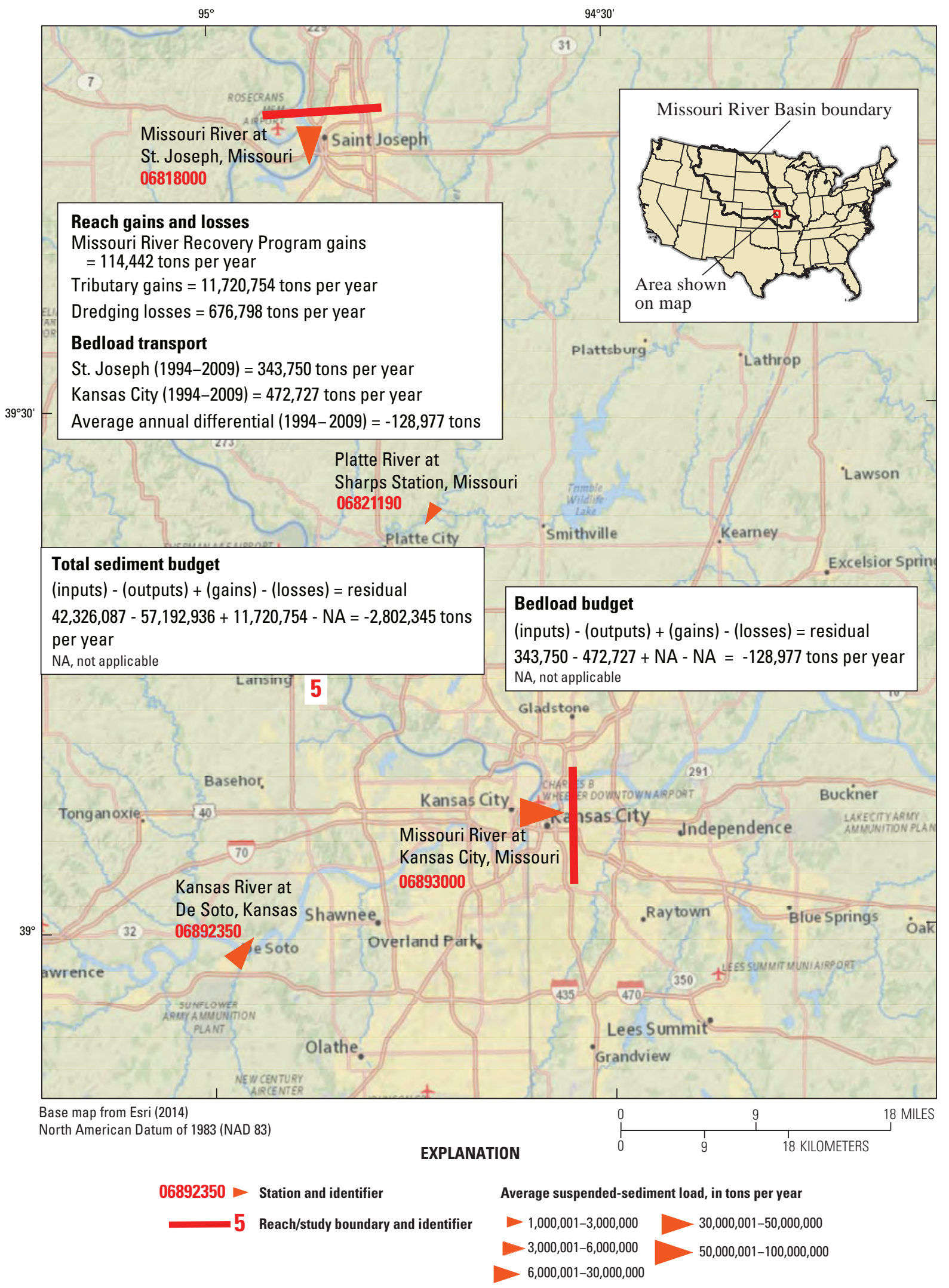

Figure 15. Long-term, average sediment budget, Lower Missouri River reach 5, St. Joseph, Missouri, to Kansas City, Missouri, 1968-2014. 


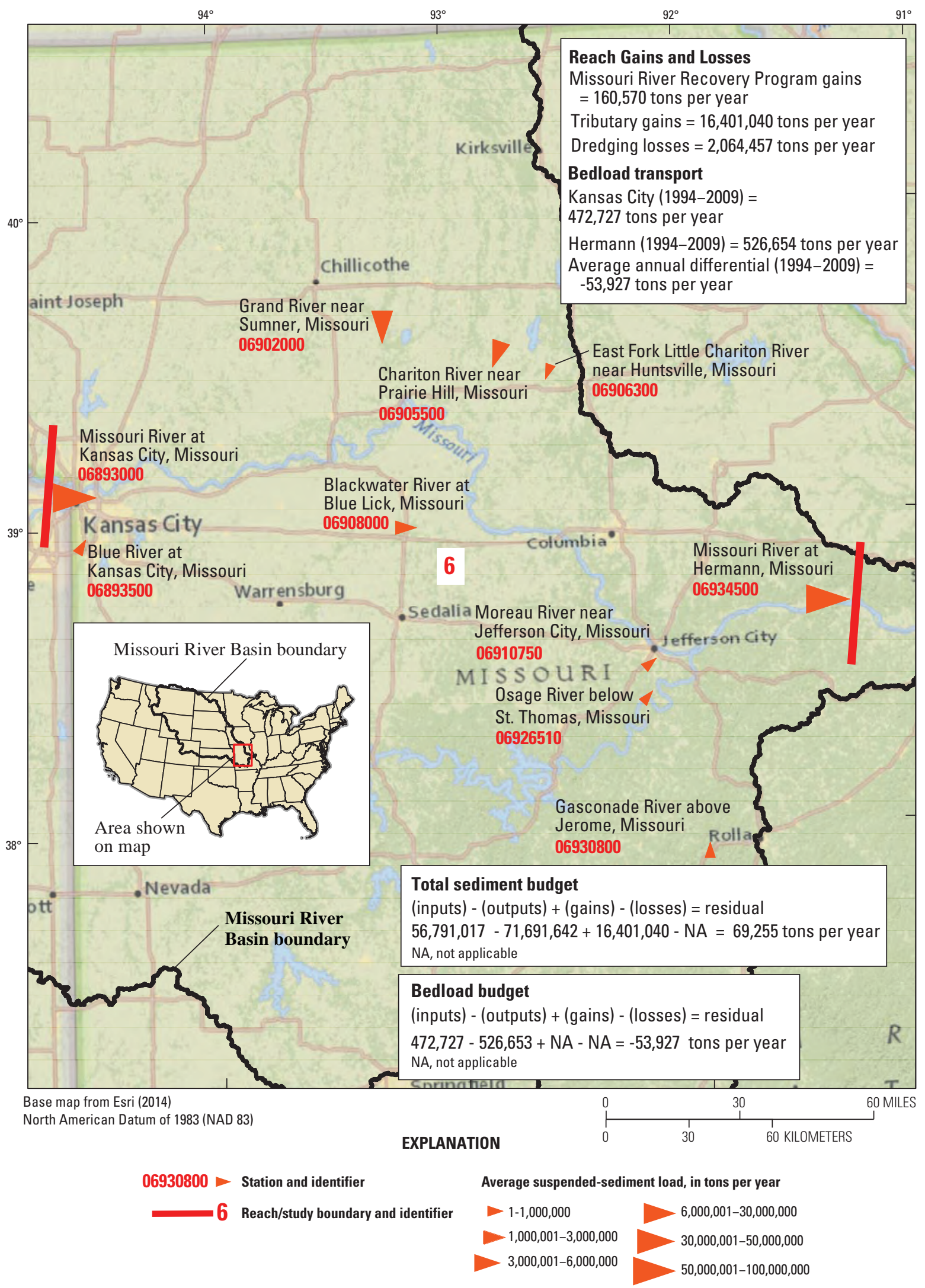

Figure 16. Long-term, average sediment budget, Missouri River reach 6, Kansas City, Missouri, to Hermann, Missouri, 1968-2014. 
For the reach from $\mathrm{K}$ ansas $\mathrm{C}$ ity to Hermann, the total SSL was 16.4 million tons per year, and 82 percent was contributed from the Grand River near Sumner, M o., and Chariton River near Prairie Hill, M o., stations. Sediment data, how ever, were unavailable since the early 1990s. The cumulative, gaged Lower M issouri River tributary SSL inputs, which are derived from about 86 percent of the interim drainage area between Gavins Point Dam and Hermann station, accounted for about 84 percent of the long-term average annual SSL at the Hermann station.

The average annual bedload transport at the $K$ ansas City station was 0.47 million tons and at the Hermann station was 0.53 million tons using 1994-2009 data from ENTRIX, Inc. (2011), and the bedload residual for the K ansas City to Hermann reach used in the 1968-2014 budget was -0.05 million tons (table 8). The average annual total M R RP gain in the reach was 0.16 million tons, and average annual total commercial dredging loss was 2.0 million tons. The corresponding stage trend for 1968-2011 in the reach indicated a change in stage from $-2 \mathrm{ft}$ (for flow of 70,000 ft $\mathrm{ft}^{3} / \mathrm{s}$ ) to $-1 \mathrm{ft}$ (for a flow of $100,000 \mathrm{ft}^{3} / \mathrm{s}$; U.S. A rmy Corps of Engineers, 2012), with a corresponding average annual flow of $87,000 \mathrm{ft}^{3} / \mathrm{s}$. Stage trends for flows of 200,000 and $300,000 \mathrm{ft}^{3} / \mathrm{s}$ indicated little change with time and stages for flows of 400,000 and 500,000 $\mathrm{ft}^{3} / \mathrm{s}$ indicated small increases of $1-2 \mathrm{ft}$. Whether the increases are the result of possible bank and flood-plain storage or if the increases are the result of levee modifications is unclear, which also is the case for stations with increasing stage trends at higher flows.

\section{Reach 7-Missouri River at Hermann, Mo., to the Mississippi River at St. Louis, Mo.}

The net suspended-sediment budget residual for the reach from the M issouri River at Hermann to the M ississippi River at St. L ouis (including the upper M ississippi River gains as measured at the Grafton station) was -7.0 million tons or -6.9 percent of the average annual SSL at the St. L ouis station (102.8 million tons; table 8; fig. 17). No major tributaries contribute sediment between the Hermann station and the mouth of the M issouri River. The 1968-2011 SSL at the Hermann station was 69 percent of the SSL at the St. L ouis station, and the average $S S L$ at the Grafton station was 23 percent of the post-impoundment SSL for the St. L ouis station. The 19942009 bedl oad estimate for the Hermann station was 0.53 million tons using data from ENTRIX, Inc. (2011); however, no long-term or annual bedload estimates were available for the Grafton or St. Louis stations. The average annual total M RRP additions in the reach were zero and the average annual commercial dredging amount in the $M$ issouri River part of the budget reach was 1.3 million tons per year. Corresponding stage trends for 1968-2009 at the St. L ouis station indicated a 0 to $-1 \mathrm{ft}$ change in stage for a constant flow of $200,000 \mathrm{ft}^{3} / \mathrm{s}$ (Watson and B iedenharn, 2009), which closely corresponds to the 1968-2009 average annual flow of $218,000 \mathrm{ft}^{3} / \mathrm{s}$ at the
St. Louis station. Stages at higher flows $(300,000-700,000$ $\mathrm{ft}^{3} / \mathrm{s}$ ) also indicated little net change with time. Despite the 0.3 percent increase in drainage area between the Hermann station and the M issouri River at St. Charles, M o., station, the estimated long-term loads between the two stations had an average 17 percent increase. The SSL estimate at the $M$ issouri River at St. Charles, M 0., station, however, is based on only three available years (2006-8) of concurrent record with the Hermann station and the uncertainty in this estimate is substantial.

\section{Annual, Monthly, and Daily SSL Budgets}

The L ower M issouri River reach from Omaha, N ebr., to N ebraska City, N ebr., had periods of concurrent record for each of the primary suspended-sediment components with which to analyze and determine a SSL budget for selected annual, monthly, and daily time increments (table 9). The determination of annual, monthly, and daily sediment budget examples are limited to this reach because data gaps, even in the SSL record for most tributary stations, generally prevent the determination of annual, monthly, and particularly daily sediment budgets in most L ower M issouri River reaches.

\section{Annual Budget}

Other than 5 consecutive years of negative annual sediment budget residuals in the early 1970s, the residuals for the O maha, N ebr., to N ebraska City, N ebr., reach were marked by substantial oscillations between years (table 9 ; fig. 18). The annual SSL budget residuals for the O maha to N ebraska City reach ranged from about -14 to 12 million tons (fig. 18). For the N ebraska City station, the budget residuals represented a range from -24 to 40 percent of the annual SSL and generally were between -20 and 20 percent. The temporal changes in the cumulative partial budget residuals (fig. 19) were poorly correlated with the comparatively steady 1968-2011 annual stage trends at the Nebraska City station for a flow of 30,000 $\mathrm{ft}^{3} / \mathrm{s}$ (fig. 20). The steady stages provide an indication that the annual budget residuals during this period should be minimal. The comparison displays the net variability in the annual SSL budget components and provides an indication of the net magnitude of missing budget components (bedload, sediment storage, and sampling and computation errors). The example also indicates that even in this "simple" and data rich reach, the devel opment of an accurate detailed sediment budget is limited by data gaps.

\section{Monthly Budget}

A monthly SSL budget was estimated for the O maha, N ebr., to N ebraska City, N ebr., reach using concurrent record for 1968-76. A monthly SSL budget could account for sediment transport differences on the time scale of large 


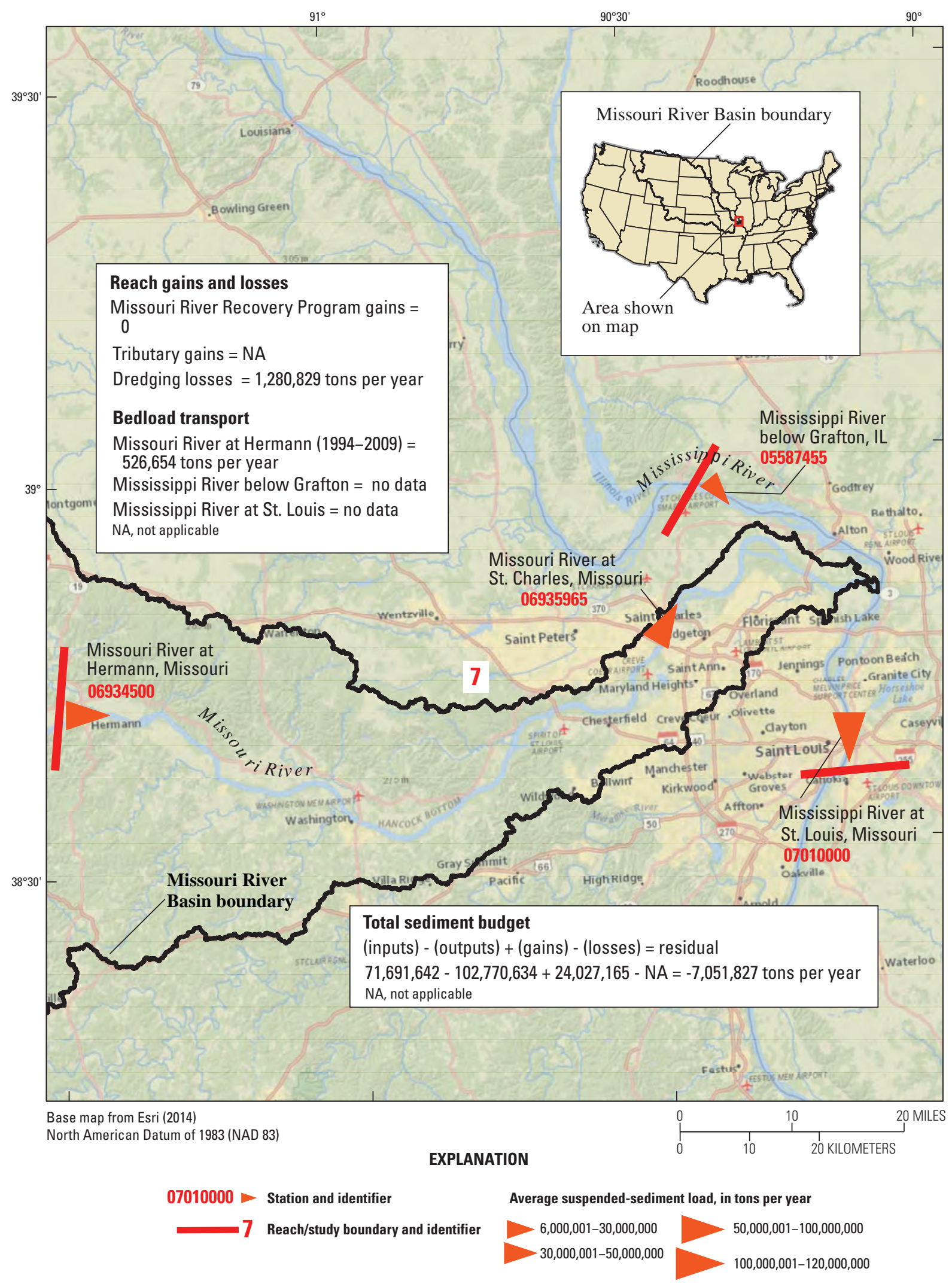

Figure 17. Long-term average sediment budget, Lower Missouri River reach 7, Hermann, Missouri, to St. Louis, Missouri, 1968-2014. 


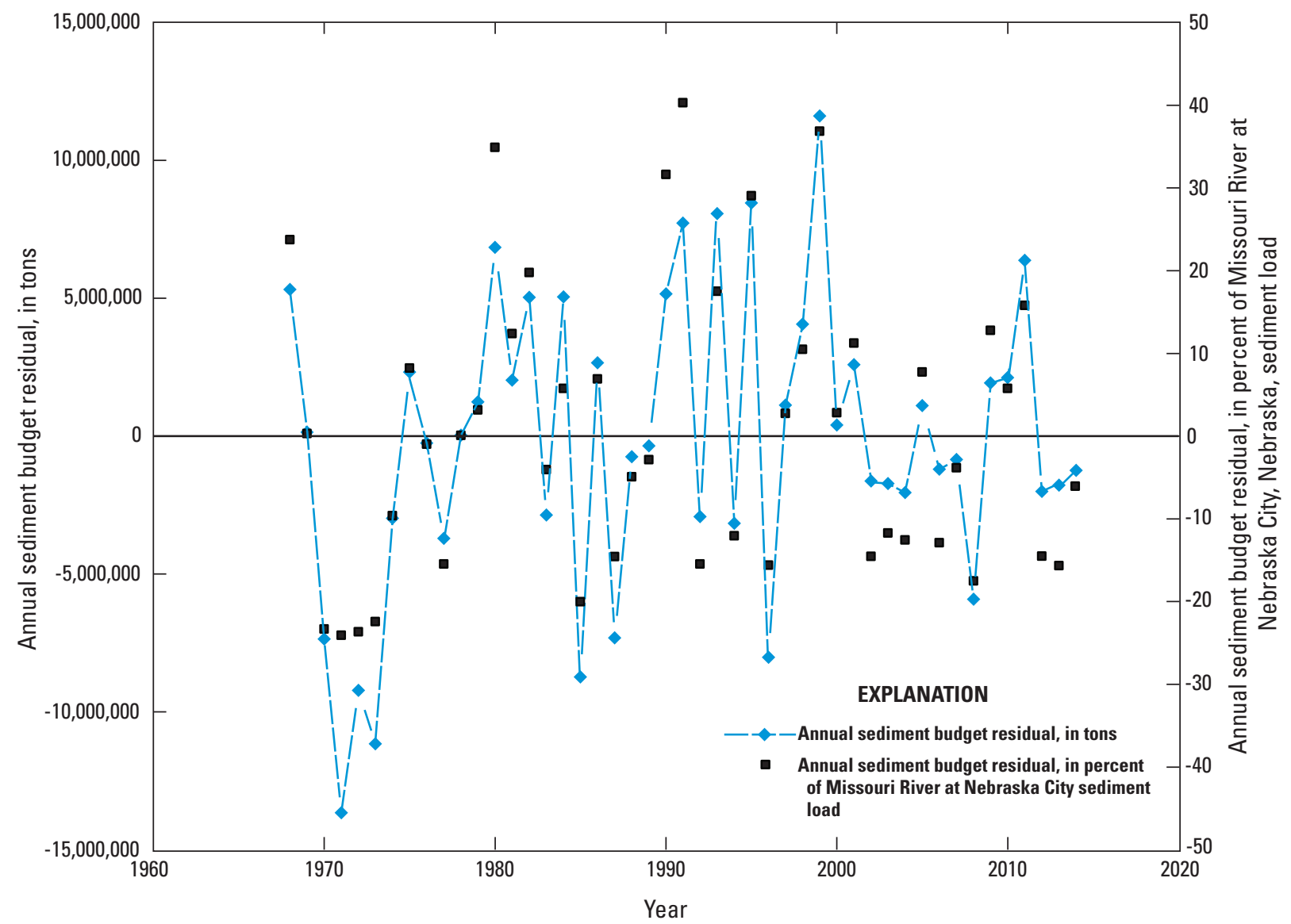

Figure 18. Annual, monthly, and daily sediment budget for the Lower Missouri River, reach 3, Omaha, Nebraska, to Nebraska City, Nebraska, 1968-2014.

hydrologic events that include regional flooding or seasonal changes in sediment transport. The SSL monthly budget residuals for the $O$ maha to $\mathrm{N}$ ebraska City reach ranged from about -7 to 2 million tons (table 9; fig. 21). For the Nebraska City station, the budget residuals represented a range from about - 60 to 50 percent of the monthly SSL s and generally were between -40 and 40 percent. The monthly residual plot indicates that negative annual budget residuals; for example, those in 1970-73, primarily can be attributed to a few months of large negative residuals in each year.

\section{Daily Budget}

Similar to the computation of the monthly SSL budget, concurrent daily SSL $s$ also were available for the O maha, N ebr., to N ebraska City, N ebr., reach for 1968-76. A complicating factor in estimating a sediment budget residual at the daily time scale is accounting for the travel time, or lag, betw een stations in the reach. The sediment travel time can substantially differ from the daily SSL computation interval; therefore, sediment travel times may not correspond to an even daily computation increment. Lag times used in analyses differed between stations; however, for simplicity, lag times were uniform between station data pairs. The lag time combination that minimized the overall average budget residual for each reach was determined and used for all conditions. In reality, the lag or travel times between stations will differ with streamflows and water velocities. To minimize the net daily budget residuals, a 1-day lag time was applied in the budget calculations to the M issouri River at Omaha, N ebr., station and Platte River at L ouisville, N ebr., station records.

The magnitude of daily sediment budget residuals in the O maha to N ebraska City reach ranged from about - 1.6 to 0.60 million tons (table 9; fig. 22). For the Nebraska City station, the residuals represented a range from - 90 to 260 percent of the daily SSL $s$ and generally were between -75 and 75 percent. The skew in positive residuals expressed as a percent of output load (fig. 22) generally coincided with periods of high SSL $s$ at the $O$ maha station. The skew in positive residuals may be the result of sediment storage within the main stem or may be from inadequately accounting for changes in travel times between the $\mathrm{O}$ maha and $\mathrm{N}$ ebraska City stations in the daily budget computations. The increase in the value of the ratio of budget residual to output SSL in the annual (20 percent), monthly (40 percent), and daily (75 percent) 


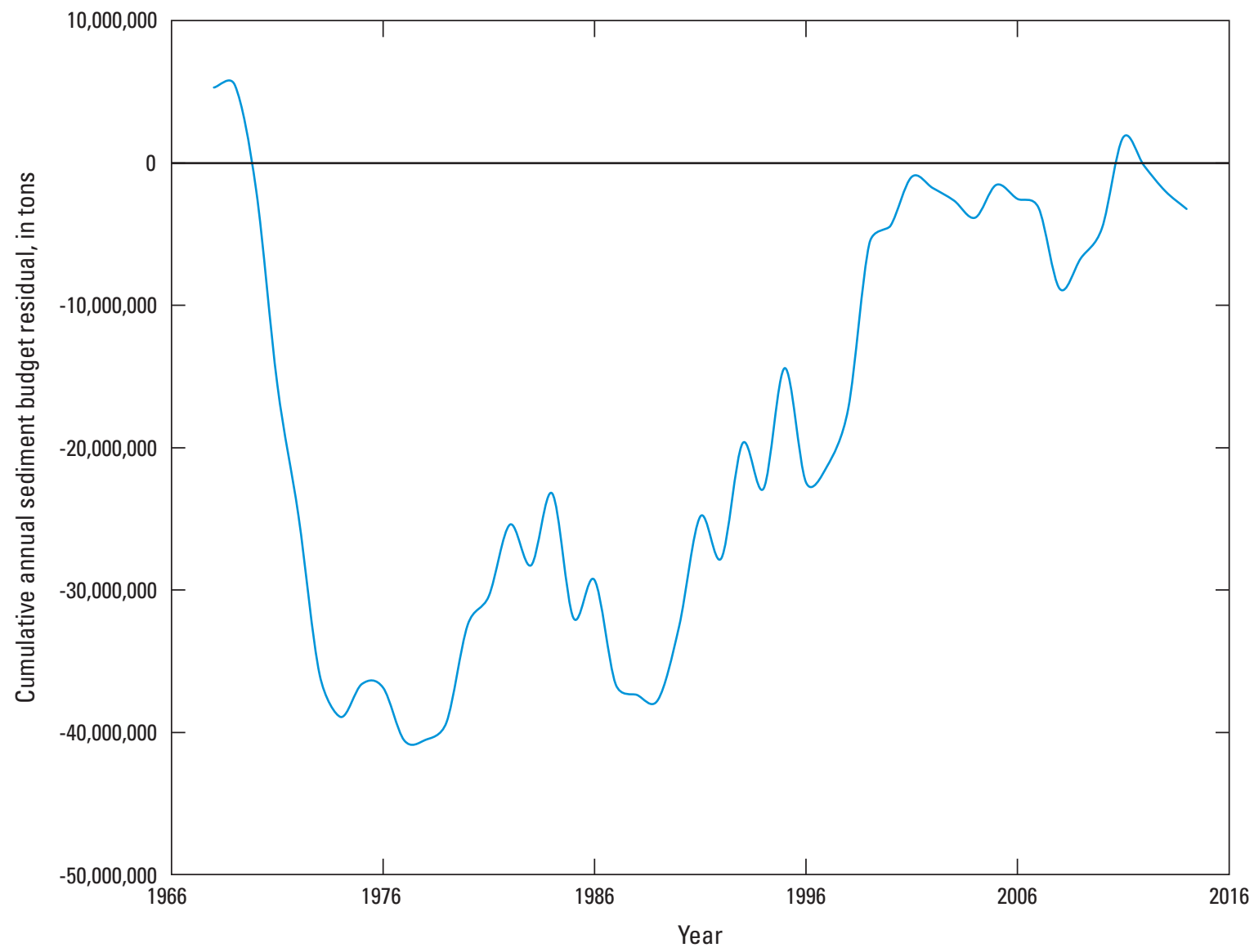

Figure 19. Cumulative annual sediment budget residuals for Lower Missouri River reach 3, Omaha, Nebraska, to Nebraska City, Nebraska, 1968-2014.

budget determinations demonstrates the greater variability and uncertainty associated with smaller incremental estimates of the budget residual and station SSLS.

The daily incremental SSL data allow for the determination of budget residuals during specific hydrological or short-term periods of interest not represented in monthly or annual budgets and help to further discern the episodic nature of sediment transport. For example, the daily budget residuals during floods in the Omaha to Nebraska City reach indicated a consistent shift in sediment transport dynamics from a negative residual condition to a positive residual condition near the flood peak or on the recession side of the peaks of three floods during 1968-78 (fig. 23). The days of large positive budget residuals on the flood recession may correspond to periods of sediment storage on the flood plain or in the channel.

\section{Bedload Component of Sediment Budgets}

For the M issouri River, substantially less bedload transport data are available than suspended-sediment data, and the data that do exist represent sporadic and discrete measurements or theoretical estimates at main-stem stations (table 6), limiting the potential for incorporating bedload into sediment budgets. A vailable bedload data were incorporated into long-term reach budgets for the N ebraska City to St. J oseph stations, St. J oseph to K ansas City stations, and Kansas City to Hermann stations. B edload data were limited for these selected main-stem stations to stations using theoretical bedload-streamflow ratings. Available measured and computed bedload transport data for the L ower M issouri and M ississippi River stations used in this study for 1950-2014 are summarized in figure 24 .

\section{Sediment Data Gaps and Uncertainties}

Sediment data gaps and uncertainties, as related to the development of a sediment budget for the L ower M issouri River, include factors that affect the availability, location, and accuracy of the primary budget components. Data gaps and uncertainties differ for each budget component, for each reach, and with time. Ultimately, identification of data gaps and limitations of sediment-budget components are determined by the desired applications and the corresponding time increment and spatial requirements of those applications. 


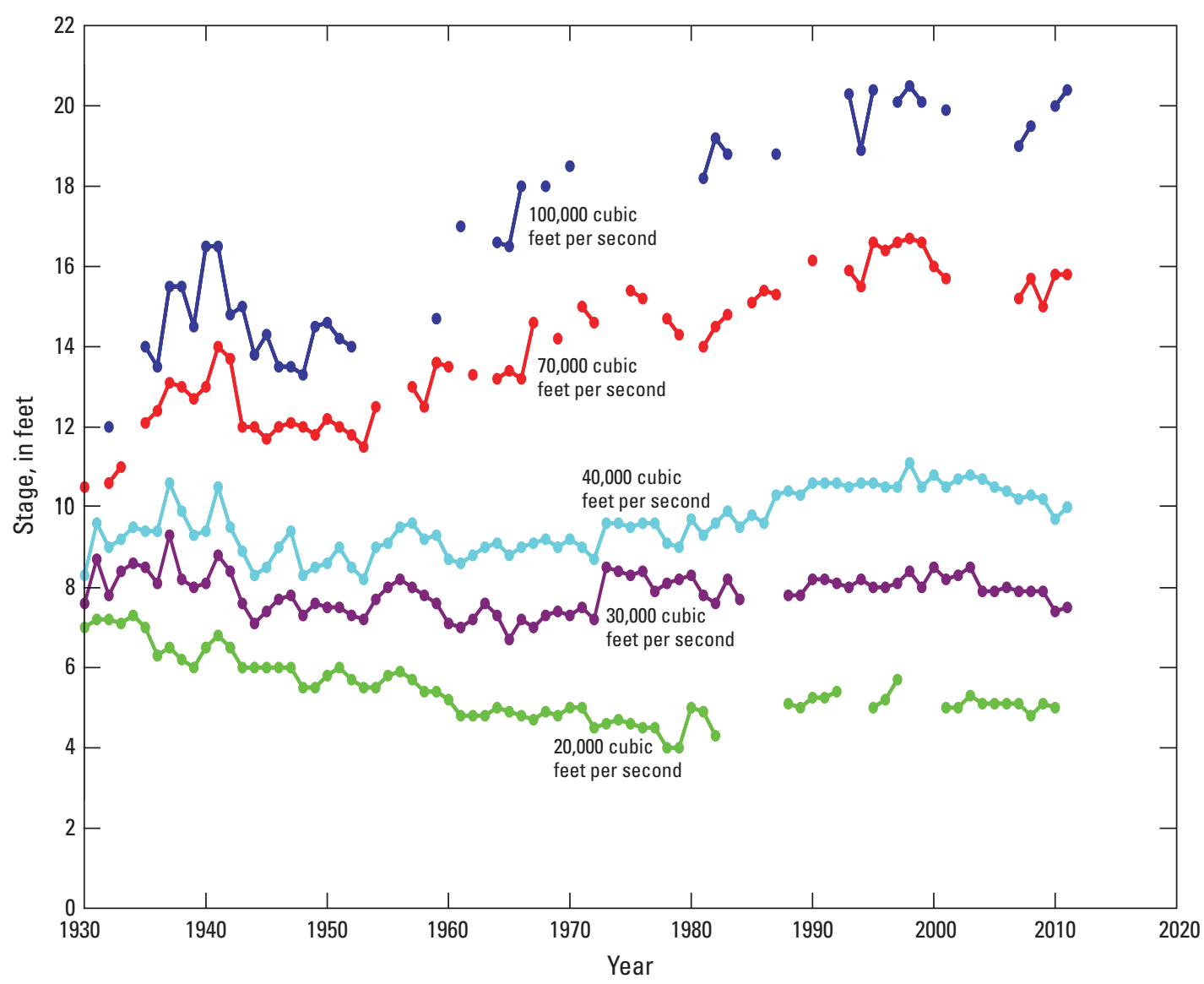

Figure 20. Temporal trend in the stage of the Missouri River at Nebraska City, Nebraska, station for selected constant streamflows, 1930-2011 (U.S. Army Corps of Engineers, 2012).

\section{Data Gaps}

A $n$ accurate total sediment budget is developed by having concurrent data for all suspended-sediment and bedload components in equation 1 for a reach of interest throughout a time period. A complete sediment budget, with concurrent record for suspended-sediment and bedload components, is unavailable for any reach and period in the L ower M issouri River; therefore, a generalized sediment budget was the remaining alternative. A generalized sediment budget uses the best estimates based on some stations with complete measured record and some stations with partially or fully estimated record.

U ncertainty in the long-term, annual, monthly, and daily budgets was introduced because SSL budgets were estimated based on the available partial record. The uncertainty increased with an increase in the period of missing record. $M$ ore sediment record is missing in the latter part of the study period at most tributary stations, and considering the declines in SSC and SSL with time (figs. 7-8), the use of partial record for a long-term average may overestimate the actual averages.

$D$ ata gaps prevented the determination of reliable annual, monthly, and daily SSL budgets for most L ower M issouri
River reaches and shortened the analysis period for the reach where example budgets were developed. Currently (2016), sediment budgets are restricted to reaches defined by mainstem stations. To measure storage components, subreach budgets would require additional resources and targeted datacollection efforts, which include additional SSC monitoring, bedload measurements, and hydrographic surveys (K rahulik and others, 2015). B ecause a primary data gap in main-stem reach budgets corresponds to the paucity of tributary SSL and bedload data, the greater the local reach tributary contributions, the greater the resources that will be required to obtain finer spatial resolution or to enable sediment budgeting at short temporal increments.

B edload data gaps in the $M$ issouri River Basin are much more prevalent than suspended-sediment data gaps, and the first step in the development of reach bedload budgets would be the establishment of a standardized bedload monitoring program at main-stem and tributary stations. B edload transport is highly variable in space and time, and theoretical calculations and measurements have large uncertainties that will require careful consideration to design optimized bedloadstreamflow ratings. Because transport capacity varies with 


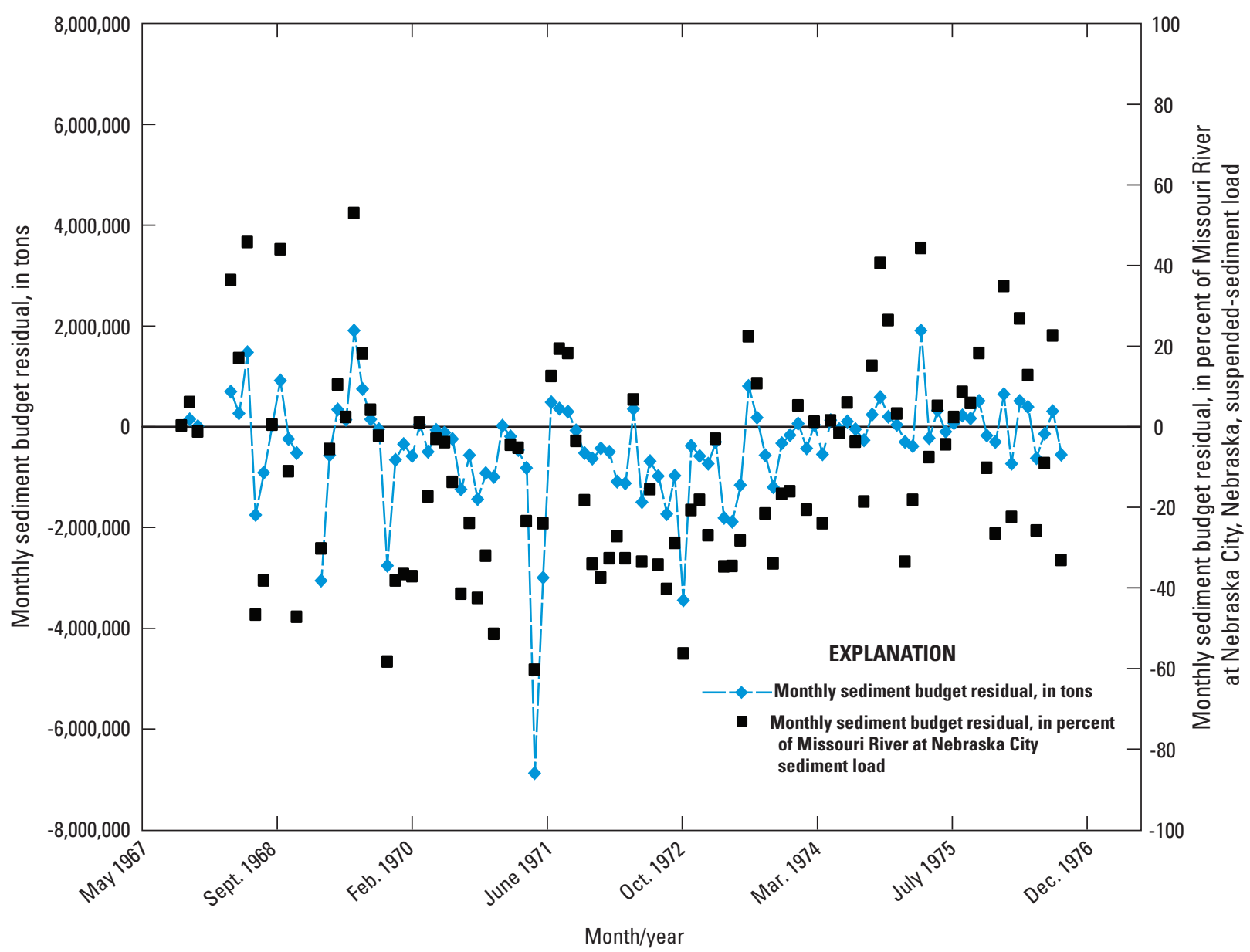

Figure 21. Monthly suspended-sediment budget residuals for Lower Missouri River reach 3, Omaha, Nebraska, to Nebraska City, Nebraska, 1968-76.

time and space, transitions between bedload and suspendedload transport need to be considered at stations designed to monitor total load; thus, a complementary deployment of suspended and bedload instrumentations and sampling designs will be required.

Sediment data gaps in the L ower M issouri River sediment budgets, in addition to bedload, include ungaged tributaries and local sediment contributions and flood-plain storage. The part of ungaged local drainage area ranged from about 0 to 65 percent in sediment budget reaches. Overall, about 15 percent of the L ow er M issouri River drainage area upstream from the Hermann station was unmonitored. M any tributary stations are not located at, or in proximity to, the mouth of the gaged tributary and, therefore, the total tributary sediment loads probably are underestimated. For example, the Hermann station is nearly 100 miles upstream from the mouth of the Missouri River; and, despite the lack of major interim tributaries, for the periods of concurrent SSL data at the Hermann station and the M issouri River at St. Charles, M o., station, the SSL s differed by an average of 17 percent. A Ithough the spatial extent of flood-plain deposition along the Lower Missouri
River has been studied after the 2011 flood (Alexander and others, 2013), such analyses or further determinations of the volume of deposits have not routinely been attempted. Such budget components are not insignificant but are difficult to quantify and, therefore, are lumped together and quantified based on the net budget residual of the quantified components. Currently (2016), the quantification of missing budget component values, therefore, cannot be differentiated from sampling and load computation errors in known budget variables.

\section{Data Uncertainties}

Data uncertainties associated with the development of a sediment budget include uncertainties associated with the collection of suspended-sediment and bedload data and the computation of SSLs. These uncertainties vary depending on the frequency of data collection, variability of conditions being represented by the discrete samples, and statistical approach to SSL computations. 


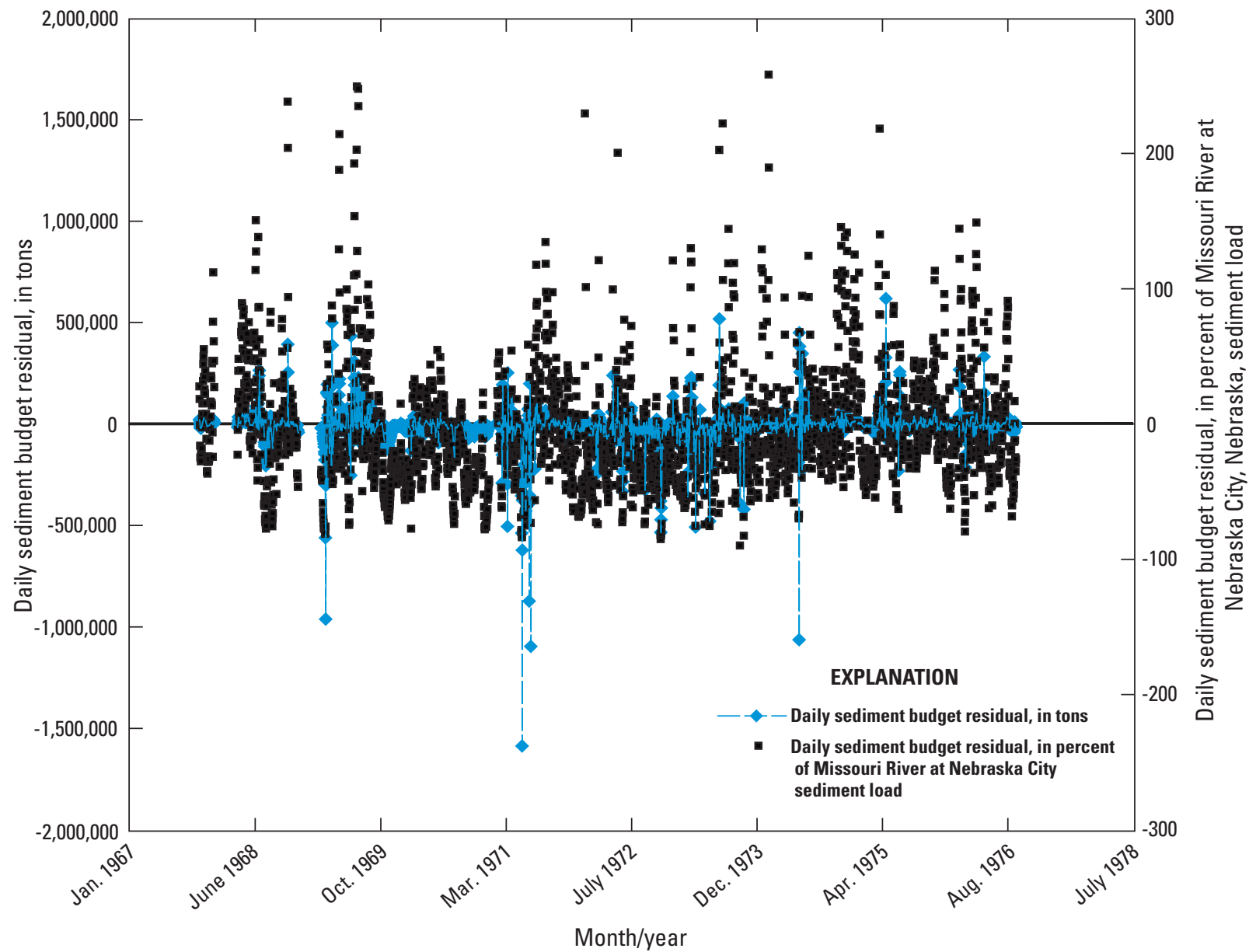

Figure 22. Daily suspended-sediment budget residuals for Lower Missouri River reach 3, Omaha, Nebraska, to Nebraska City, Nebraska, 1968-76.

\section{Suspended-Sediment Concentrations and Streamflow}

A primary issue in sampling for determination of SSCs is the uncertainty as to how well the sample is representative of the population (fig. 25). Factors contributing to this uncertainty are sampling error (for example, the nonisokinetic sampling methods or sampling an inadequate number of verticals across the channel); sampling timing and frequency (for example, sampling when the highest concentrations generally are collected, which is during the rising limb of the hydrograph, and sampling the full range of flow conditions); and uncertainties associated with laboratory analysis.

During the post-impoundment analysis period, isokinetic samplers were in use at all M issouri River Basin stations used in this study. The transition from nonisokinetic to isokinetic samplers potentially only affects the presented long-term (1930-2014) SSC and SSL changes in this study (figs. 7-8). The implementation and use of isokinetic (D-43, P-43, P-46; B enedict and N elson, 1944; Dardeau and Causey, 1990) sediment samplers on the M issouri River and its tributaries began at downstream- $M$ issouri, $K$ ansas, and most
Nebraska- stations when observations began in 1948, but the use of the samplers was not fully implemented until 1955 at upstream-Yankton and O maha- main-stem stations (the sediment record at the Sioux City station began in 1955). The Omaha sampler (Federal Interagency Sedimentation Project, 1940) was used in sediment sampling at the Yankton and 0 maha stations and at large tributary stations upstream from the Omaha station prior to the use of isokinetic samplers. A comparison study of field samples that were collected using nonisokinetic and isokinetic samplers indicated the nonisokinetic samplers tended to overestimate SSC s compared to the isokinetic samplers. Reported average sampled SSC ratios between the 0 maha sampler and the $D-43$ sampler from multiple field observations ranged from 1.06 to 1.32 , and the reported average sampled SSC ratio between the O maha and P-43 samplers was 1.13 (B enedict and N elson, 1944).

The determination of accurate SSL $s$ is dependent upon thorough and consistent sampling, analysis, and computation methods. The number of verticals used in the collection of SSC samples at M issouri River main-stem stations has differed between stations and with time; the number of vertical samples determines if the composite sample is statistically 
Figure 23. Daily suspended-sediment budget residuals during selected floods for Lower Missouri River reach 3, Omaha, Nebraska, to Nebraska City, Nebraska, 1968-76.
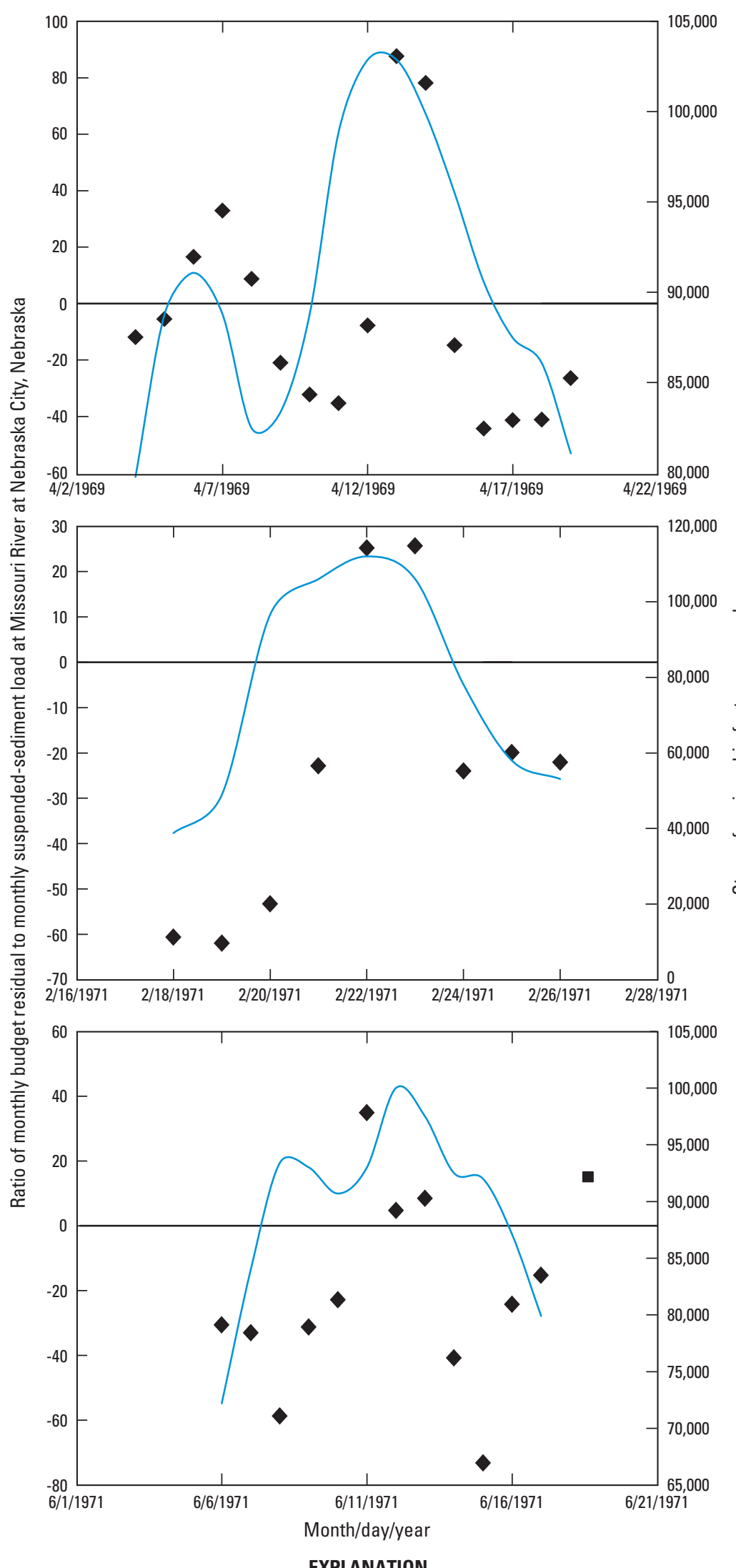

Approximate flood threshold

- Daily budget residual

Missouri River at Nebraska City,

Nebraska, streamflow 
representative of the spatial variability in SSC across the channel. Generally, three verticals have been used in SSC sample collection at stations upstream from the St. Joseph station, and five verticals have been used in SSC sample collection at the St. J oseph station and at downstream M issouri River stations. For added consistency in sediment sampling methods, the number of verticals for all M issouri River main-stem stations was modified to four verticals during the 2009 water year (U.S. Geological Survey National Water Information System, http:/dx.doi.org/10.5066/F7P55KJN). Historically, sample collection has primarily followed a regular schedule interval and, with time, such a sampling method should capture the full range of flow conditions, particularly if efforts are made to capture conditions during extreme flows. Replicate sediment samples are not routinely collected with the current (2016) sediment monitoring programs at $M$ issouri River main-stem stations, but analysis of replicate sediment samples collected during extreme flows during the 1993 flood on the Missouri River indicated the percent difference between samples to be within 8 percent (Holmes, 1996).

Daily streamflow values are used with SSC data to determine SSLs; therefore, uncertainties in streamflow data add to uncertainties in SSLs. Uncertainties in streamflows include measurement errors that generally are within about 5 percent (Turnipseed and Sauer, 2010), but the errors can be greater during periods of ice, during rapidly changing stage, and with compounding of errors in the development and application of a stage-discharge rating. Stage-discharge rating errors may be caused by stage measurement errors or rating instability resulting from changing morphology of channel bed, channel banks, or levees.

\section{Suspended-Sediment Loads}

Uncertainties in SSL s include the uncertainties associated with SSC and streamflow in addition to uncertainties specific to the SSL computations. The uncertainties in SSL s are greatest for short-interval (daily) load estimates because this time interval commonly is finer than the SSC data collection interval (near weekly to monthly but variable with time and among stations), and as a result, SSC and SSL values are determined by interpolation. A nnual loads would be expected to have less uncertainty than loads for shorter time intervals because sampling and computation errors (periods of overestimation and underestimation of SSC and SSL) would tend to "cancel out" during longer periods (Walling, 1977). Colby (1956) indicated the accuracy of sediment loads computed for a large river, such as the Mississippi River in which flow is comparatively constant, sediments are fine, and concentrations are high enough to sample accurately, to be about 10 percent. Holmes (1996) states that the annual SSL s for the Hermann, Grafton, and St. L ouis stations generally have been thought to be within 10 percent of the true value. The accuracy of annual loads could be much greater in smaller streams that have greater variability in the temporal and spatial distribution of sediment concentrations and streamflow. The USACE assigned adjective appraisals and corresponding possible outside error percentages to published historical sediment loads for $M$ issouri River Basin sediment records. A ssigned error categories included excellent (0-10 percent), good (11-20 percent), fair (21-30 percent), and poor (greater than 30 percent error). Published records for multiple stations used in this study generally were rated "good" overall, placing them in the 11-20 percent error range.

In general, the intensity and longevity of sediment record is greater at the M issouri River main-stem stations compared to tributary stations, resulting in greater uncertainty (as determined by the 1968-2014 coefficient of variation by station [table 2]) in sediment transport at most tributary stations compared to main-stem stations. The average (geometric mean) coefficients of variation of annual SSLs of Missouri River tributary stations for 1968-2014 were greater, 75.0 percent, compared to the main-stem stations, 47.1 percent. Similarly, Parker (1988) determined that the standard error of the average of annual SSLs for Lower M issouri River tributary stations was substantially larger than those of for main-stem M issouri River stations even at tributary stations of comparable record length. The greater variability of flow and sediment transport at the tributary stations may be the determining factor in the greater coefficient of variation for tributaries because even the Platte River at L ouisville, N ebr., station (a tributary station with full annual record during 1968-2014) had a coefficient of variation that was high ( 88 percent). The lower coefficient of variation at main-stem stations compared to tributaries, therefore, primarily is the result of the lower variability in streamflow and sediment discharge identified at main-stem stations. To obtain similar accuracy between SSL $s$ at main-stem and tributary stations, a longer period of record is required of the tributary stations (N ordin and M eade, 1981). During 1968-2014, however, the average M issouri River main-stem station record was much more complete (average 87 percent) than the tributary station record (average 28 percent). The SSL s of tributaries upstream from the Hermann station account for 84 percent of the 1968-2014 average SSL for the Hermann station; however, only about 20 percent of SSC samples collected in 2014 at the $M$ issouri River Basin stations used in this study were collected at tributary stations.

A n example of how the frequency of SSC sampling could affect the determination of SSL $s$ at a particular station is available for the Hermann station during 1949-2009. The total number of annual SSC samples available for analysis at the Hermann station ranged from 12 to 191 samples (fig. 26). The coefficient of variation of the annual SSL computed using annual LOADEST regression models generally changed inversely with the number of annual sediment samples and ranged from 5 to about 20 percent. 

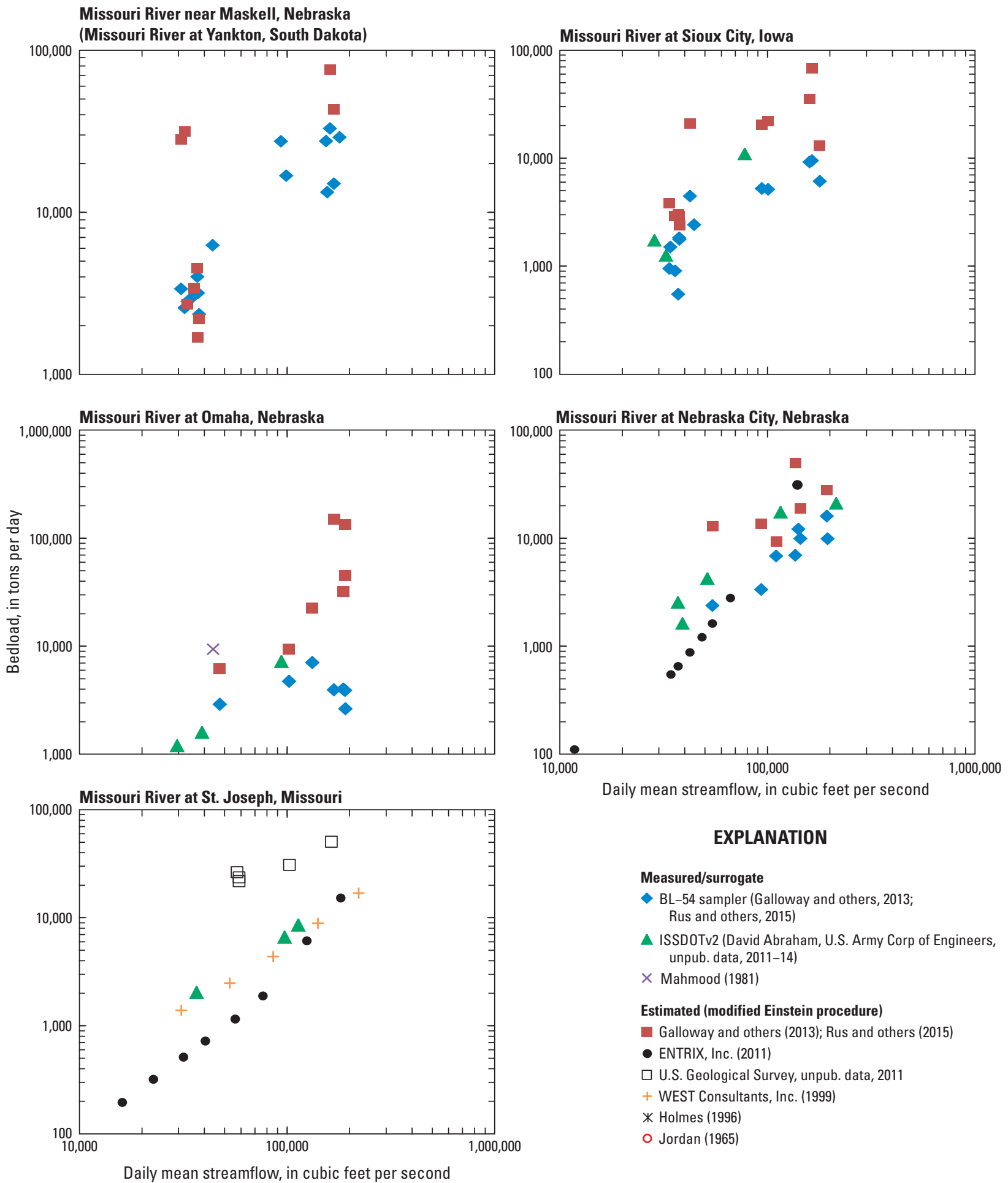

\section{EXPLANATION}

Measured/surrogate

- BL-54 sampler (Galloway and others, 2013: Rus and others, 2015)

A ISSDOTv2 (David Abraham, U.S. Army Corp of Engineers, unpub. data, 2011-14)

$\times$ Mahmood (1981)

Estimated (modified Einstein procedure)

Galloway and others (2013); Rus and others (2015)

- ENTRIX, Inc. (2011)

$\square$ U.S. Geological Survey, unpub. data, 2011

+ WEST Consultants, Inc. (1999)

* Holmes (1996)

O Jordan (1965)

Figure 24. Bedload and daily average streamflow for Lower Missouri River and Mississippi River main-stem stations, 1950-2014.

\section{Bedload}

The large documented temporal and spatial variability in bedload transport (Hubbell, 1964; Edwards and Glysson, 1999) limits the capability to capture a truly representative sample. Gaeuman and J acobson (2007) state that physical samples of bedload are subject to substantial errors in field conditions. A dditionally, despite the availability and use of numerous theoretical equations for the prediction of bedload and total-sediment transport, Gomez (2006) states that "it is not yet possible to make reliable predictions of bedloadtransport rates". Subsequent research into bedload estimates 

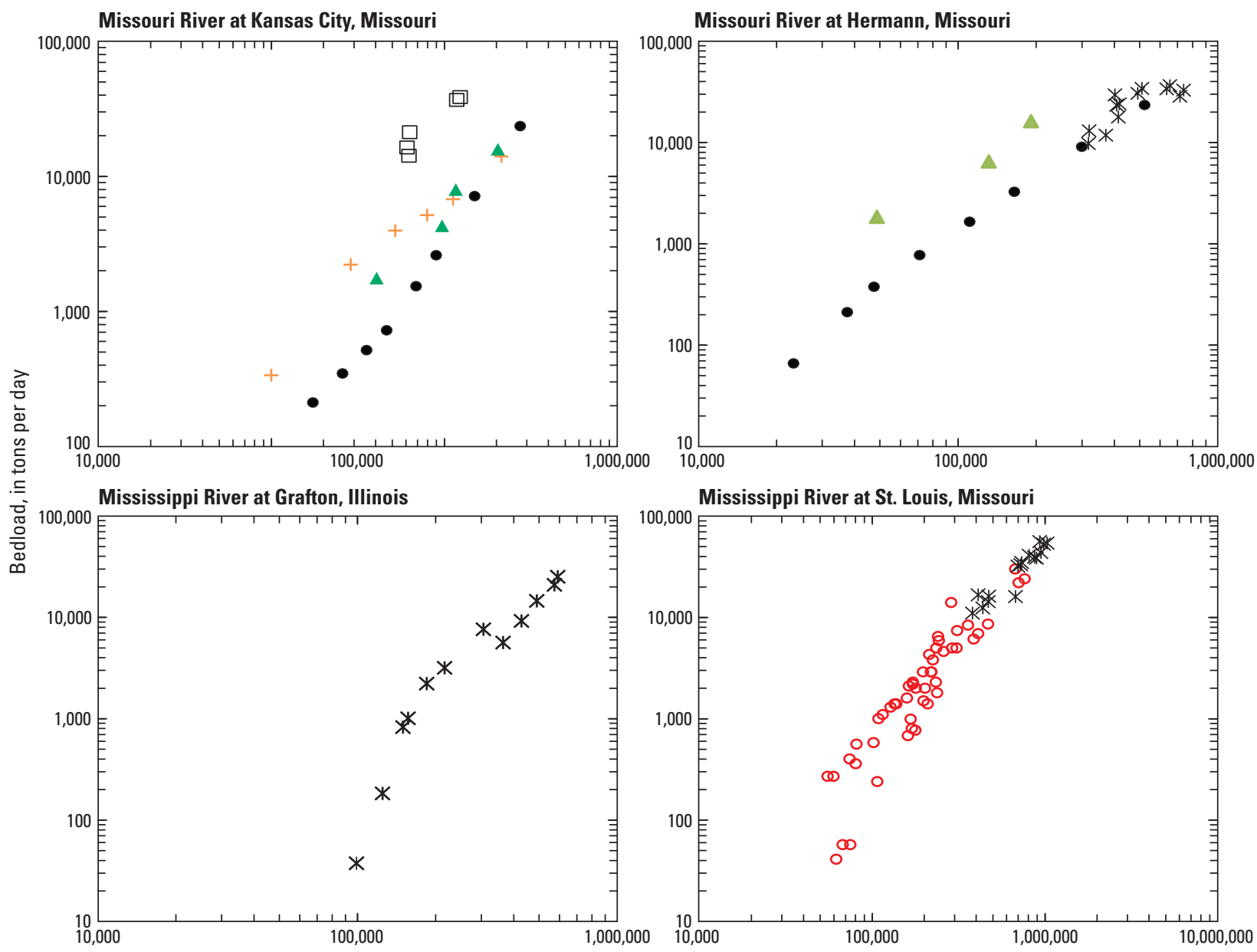

Daily mean streamflow, in cubic feet per second

\section{EXPLANATION}

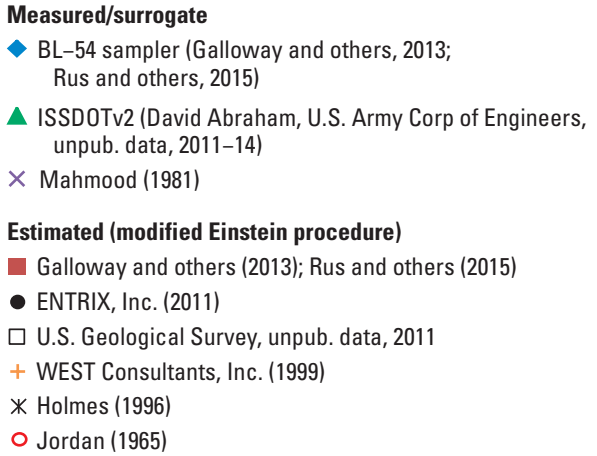

Figure 24. Bedload and daily average streamflow for Lower Missouri River and Mississippi River main-stem stations, 1950-2014.-Continued

utilizing time-lagged channel surveys, including the ISSDOTV2 method (A braham, 2009) and that of M CElroy and M ohrig (2009), are under evaluation. A lthough the absolute accuracy of bedload measurements from the ISSD 0Tv2 method has yet to be determined, the methodology has been validated in flume studies (Abraham and others, 2011; Abraham and others, 2015), and the variations of data about the average for $\mathrm{M}$ issouri River bedload estimates were generally between 20 and 30 percent (A braham and Pratt, 2010) with maximum errors between 55 and 80 percent. A dditional modifications to the method have since been introduced to limit measurement bias (Shelley and others, 2013). 


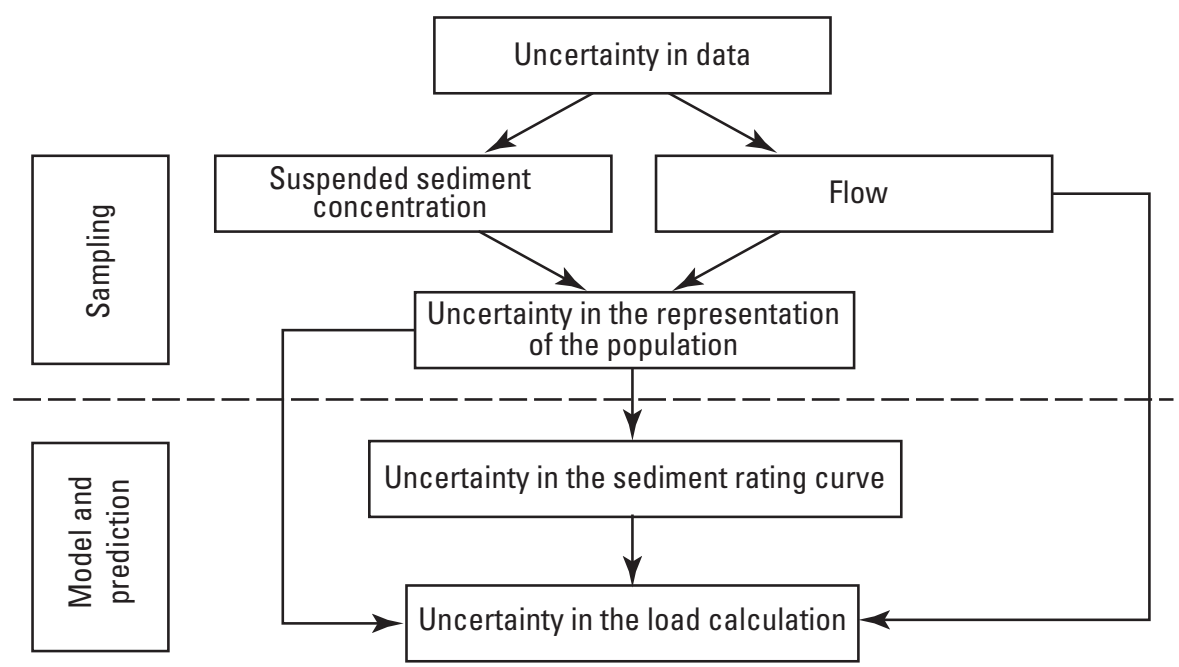

Figure 25. Primary sources of uncertainty in the computation of suspended-sediment loads (Smith and Croke, 2005).

\section{Surrogate Methods for Determination of Sediment Transport}

Surrogate methods for the characterization of sediments, including concentrations and fluxes of suspended sediments and bedload, are continually being developed to provide realtime continuous measurements, lower monitoring costs, provide greater safety in sampling, and provide a more accurate (reduce uncertainty) means of determining sediment transport in rivers and streams (Gray and Gartner, 2009). A pplication of such methods for the determination of SSC and bedload data within the M issouri River Basin can assist in the determination of sediment budgets at a variety of temporal and spatial scales. A summary of the primary surrogate techniques used to determine sediment characteristics on the M issouri River including technologies in development is provided in the following sections.

\section{Suspended-Sediment Concentrations}

The use of continuous bulk optical properties of water (turbidity) is the most commonly used surrogate for SSCS and is currently (2016) collected at three main-stem M issouri River stations (N ebraska City, St. J oseph, and Hermann), and partial annual record is available at one primary tributary station (Platte River at Louisville, N ebr.). The use of turbidity record and regression models between turbidity and SSC previously have been used in the computation of published annual SSL $s$ at several M issouri River main-stem stations (H eimann and others, 2010) and are currently (2016) used in the computation of daily SSL $s$ at the St. J oseph and Hermann stations (the models and supporting documentation are available on the N ational Real-Time Water-Q uality Web site http://nrtwq. usgs.gov/). Regression models for SSC using turbidity as the explanatory variable have been demonstrated to have a higher coefficient of determination $\left(\mathrm{r}^{2}\right)$ than models using streamflow (Rasmussen and others, 2009). Lewis (1996) indicated that regression models using turbidity instead of streamflow improved the root-mean-squared errors of sedi $\neg$ ment rating curve estimates of SSC by 7-15 percent.

Once an initial regression model is developed relating turbidity and SSC, SSC samples can be collected less frequently, the long-term operation costs for a sediment monitoring station can be reduced, and predictive uncertainty of estimates can be quantified. A continuous sediment surrogate also can allow for the availability of data during episodic events that may be difficult to obtain otherwise (Rasmussen and others, 2009). A n established regression model between SSC and turbidity also can be used to quantify SSC and SSL at shorter time increments (for example, hourly) and at specific subreach locations of interest. A ccording to Rasmussen and others (2009), the use of linear regres $\neg$ sion models between SSC and turbidity can provide a more reliable SSC than either the Porterfield (1972) method or traditional transport-curve (sediment rating curve) method (Walling, 1977; Horowitz, 2003; Putnam and Pope, 2003). The turbidity surrogate method also provides the added benefit of being able to quantify uncertainty in SSC estimates by means of prediction intervals (R asmussen and others, 2009) and could possibly be used to close the accuracy gap between tributary and main-stem sediment record.

The use of other surrogate techniques (such as backscatter and laser diffraction techniques alone or in combination with turbidity data) to determine suspended sediment is increasing. These techniques can be used as stand-alone systems or in combination to augment or extend turbidity data and to provide continuous SSC and particle-size class information (Voichick and Topping, 2014). The SSC is determined 


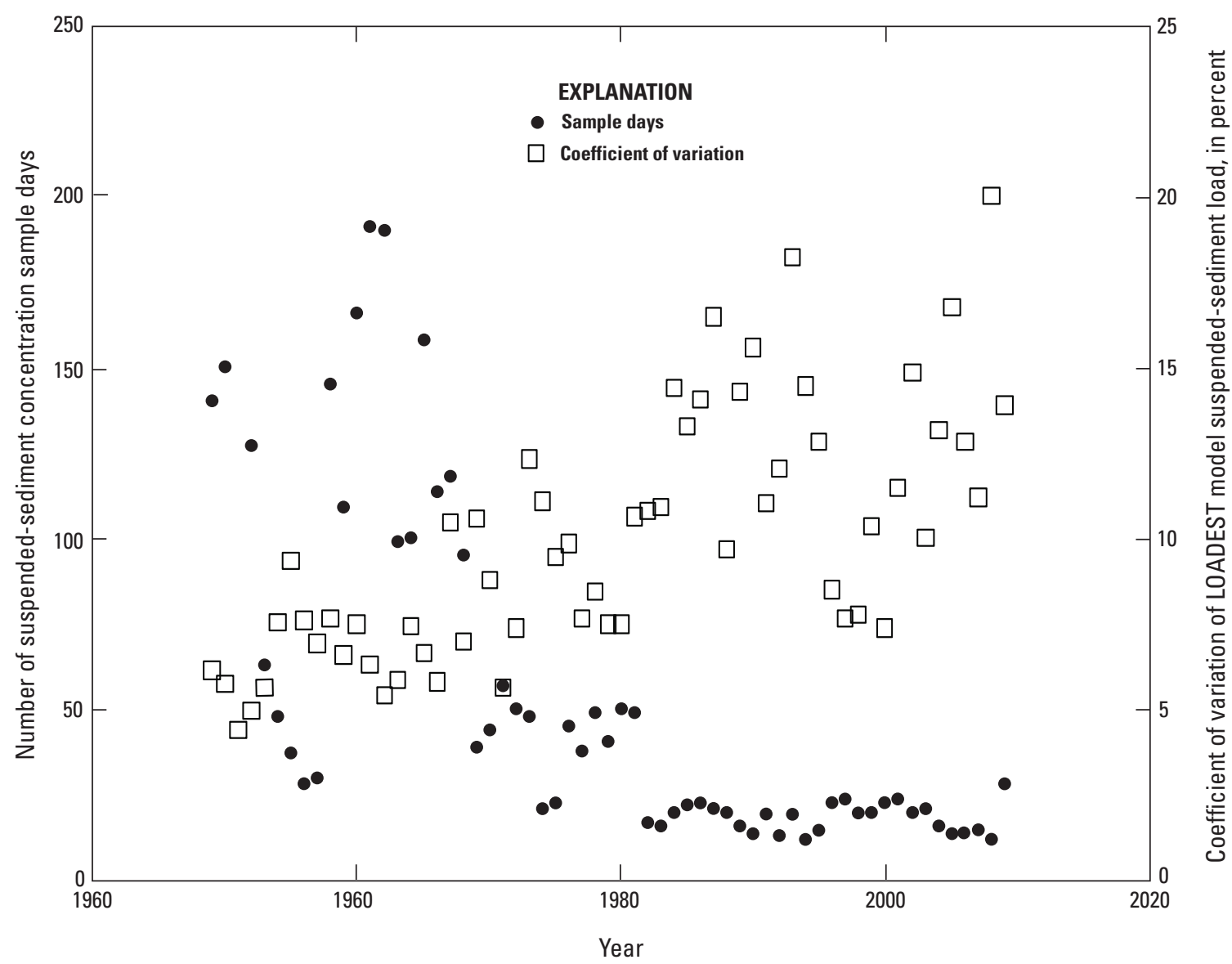

Figure 26. Graph showing inverse trends with time of the number of suspended-sediment concentration samples per year and the corresponding coefficient of variation of annual suspended-sediment load estimates, Missouri River at Hermann, Missouri, 1949-2009. (Loads computed using annual LOADEST regression models: Heimann and others, 2010).

by a site-specific relation between SSC determined for discrete samples and acoustic backscatter from suspended-sediment particles crossing the beam emitted by hydroacoustic instruments. The instrumentation includes acoustic velocity meters and acoustic Doppler velocity meters, and favorable results have been provided in applications throughout the U nited States, including Idaho and Washington (Wood, 2010; Wood and Teasdale, 2013); Vermont (Medalie and others, 2014); the M ississippi River delta in L ouisiana (Perkey and others, 2010; Heath and others, 2015); Hudson River in New York, (Wall and others, 2006); and the Colorado River in Colorado (Topping and others, 2004; Topping and others, 2006; Voichick and Topping, 2014). A multifrequency acoustic Doppler velocity meter array currently (2016) is being tested at an installation at the N ebraska City station ( $\mathrm{N}$ ania, 2015). M ultifrequency arrays have the potential to provide information on sediment size fractions (Wood, 2014) in addition to SSC. A ccording to Gray and Gartner (2009) "M ultifrequency hydroacoustics shows the most promise for revolutionizing collection of continuous suspended-sediment data by instruments that require only periodic calibration for correlation to average concentrations in river cross sections".
The use of laser diffraction is another means of providing continuous real-time SSC and sediment particle-size data. Laser diffraction instruments measure optical scattering of light with a wide range of angles, providing a multiparameter measurement of 32 particle-size classes (A grawal and others, 2008; Gray and Gartner, 2009; Gray and others, 2010). A complicating factor in the use of laser diffraction instruments to determine SSC is that laser diffraction instruments estimate a volumetric concentration of sediment as opposed to a mass concentration (A grawal and others, 2008). To determine SSC, therefore, particle density estimates are required to make the conversion to mass concentrations or the development of a site-specific regression model that relates SSC to volumetric concentration is required. The site-specific regression model would be similar to the models used with turbidity as the surrogate. The applicability of this technique to determine SSC and size fractions has been demonstrated on a small M issouri River tributary (Hubbart, 2012) and currently (2016) is being tested at the N ebraska City station (N ania, 2015). 


\section{Bedload}

Surrogate methods for the determination of bedload, including active and passive-type samplers, are an alternative to traditional measurements and theoretical computations. The traditional bedload samplers (H elley Smith, B L-84 sampler; Davis, 2005) and theoretical computations of bedload by total sediment transport equations (for example, modified Einstein procedure) used at M issouri River main-stem stations have limitations in representing true bedload transport as described in the "B edload" subsection of the "Data Uncertainties" section. Traditional bedload samplers include box or basket samplers, pan or tray samplers, pressure-difference samplers, and trough or pit samplers (G ray and others, 2010). In theory, the traditional method could be used to calibrate the surrogate method and provide information on accuracy and spatial and temporal differences compared to this standard method. A difficulty in applying surrogate bedload methods to the Lower $M$ issouri River is the inability to calibrate the surrogate technologies to "true" measurements because of the limitations in the traditional measurements and theoretical techniques (Gaeuman and J acobson, 2007).

Surrogate bedload technologies, operating with activeand passive-type sensors, have the advantage in many cases to be applied continuously and automatically at a river site (G ray and others, 2010). A ctive or direct sensors include acoustic Doppler current profilers, sonar (including estimation of bedload transport rates from bathymetric differencing), radar, and smart sensors. Passive sensors include geophones (pipes or plates) that are in direct contact with the streambed, hydrophones that are deployed in the water column ( $M$ arineau and others, 2012), impact sensors (Hilldale and others, 2014), and magnetic detection. A sonar (bathymetric differencing) technique has been the surrogate technique most applied to date (2016) in the Lower M issouri River. M cElroy and M ohrig (2009), A braham (2009), and A braham and others (2010) present methodologies for relating time-lapsed bed-form data to bedload transport. The USA CE (A braham and Pratt, 2010; 2014, unpub. data) and USGS (2011, unpub. data) have collected time-lapsed, bed-form data using a multibeam echo sounder at multiple M issouri River locations. The purpose of the time-lapsed, bed-form data are to develop standardized methodology for collecting and processing bed-form data that will be used as a surrogate for determining bedl oad transport.

\section{Summary}

Sediment budgets of the L ower M issouri River were developed in a study led by the U.S. G eological Survey, in cooperation with the U.S. A rmy Corps of Engineers. The sediment budgets included suspended-sediment data and, when and where available, bedload data. The scope of the study included the development of sediment budgets for the postimpoundment period (1968-2014) for main-stem reaches of the Lower M issouri River-from Yankton, South Dakota, to St. L ouis, M issouri. Included in the analysis were $31 \mathrm{M}$ issouri River main-stem and tributary stations and two M ississippi River stations- the M ississippi River below Grafton, Illinois, and the M ississippi River at St. Louis, M 0.

Annual flow-weighted suspended-sediment concentration and annual suspended-sediment loads for the study sites indicated declining suspended-sediment concentrations and loads at most stations during 1930-2014. The temporal changes in flow-adjusted suspended-sediment concentrations analyzed at main-stem M issouri River stations indicated an overall downward change in concentrations between 1968 and 2014. The declines in flow-adjusted concentrations at the Missouri River at Sioux City, Iowa; M issouri River at Omaha, N ebraska; and M issouri River at N ebraska City, N ebr., stations were greater between 1968 and about 1990 than between 1990 and 2014, and changes in flow-adjusted suspended-sediment concentrations for the M issouri River at St. Joseph, M 0.; M issouri River at $\mathrm{K}$ ansas $\mathrm{City}, \mathrm{M}$ 0.; and $\mathrm{M}$ issouri River at $\mathrm{H}$ ermann, $\mathrm{M}$ 0., stations were greater between 1990 and 2014 than before 1990. This difference could be an indication of Iongitudinal differences in the temporal adjustment of the Lower Missouri River to post-impoundment (and other factors affecting sediment supply) conditions in sediment transport. Temporary declines in flow-adjusted suspended-sediment concentrations during and following large floods were evident but generally returned to near pre-flood values within about 6 months.

A generalized long-term (1968-2014) sediment budget for seven reaches, defined by main-stem stations, was determined for the post-impoundment period (1968-2014). L ong-term average annual suspended-sediment loads among the M issouri River main-stem stations ranged from 0.33 million tons at the M issouri River at Yankton, S. Dak., station to 71.2 million tons at the M issouri River at Hermann, M 0. , station. Gaged tributary gains accounted for 9-36 percent of the local reach budgets, and cumulative gaged tributary contributions accounted for 84 percent of the long-term average suspended-sediment load at the M issouri River at Hermann, M o., station. A Ithough the budgets generally were incomplete and missing bedload, storage, and ungaged tributary contributions (accounting for 20 percent of local reach drainage area, on average), the budget residuals for six of the seven reaches ranged from -7.0 to 1.7 million tons, or from -9.2 to 4.0 percent of the reach output suspended-sediment load, and were within the 10 percent reported measurement error of annual suspended-sediment loads for large rivers. The remaining reach, Y ankton, S. Dak., to Sioux City, Iowa, had an average budget residual of -9.8 million tons per year (-88 percent of the reach output suspended-sediment load), indicating the input suspended-sediment load and reach gains from gaged tributaries accounted for a small part of output suspendedsediment load.

The L ower M issouri River reach from O maha, N ebr., to N ebraska City, N ebr., had periods of concurrent sediment data for budget components with which to analyze and determine a suspended-sediment budget for selected annual, monthly, and 
daily time increments. The temporal changes in the cumulative annual budget residuals were poorly correlated with the comparatively-steady 1968-2011 annual stage trends at the N ebraska City, N ebr., station. The comparison provides an indication of the net variability in the annual budget residuals and the net magnitude of missing budget components (bedload, sediment storage, and sampling and computation errors). The example also indicates that even in this "simple" and data rich reach, the development of an accurate detailed sediment budget is limited by data gaps.

A monthly suspended-sediment load budget could account for sediment transport differences on the time scale of large hydrologic events that include regional flooding or seasonal changes in sediment transport. The monthly budget residual plot indicates that negative annual budget residuals primarily can be attributed to a few months of large negative residuals in each year. The daily incremental data allow for the determination of budget residuals during specific hydrological or short-term periods of interest not captured in monthly or annual budgets. The increase in the value of the ratio of budget residual to reach output suspended-sediment load in the annual (20 percent), monthly (40 percent), and daily (75 percent) budget determinations demonstrates the greater variability and uncertainty associated with smaller incremental estimates of the budget residual and station suspended-sediment loads. The daily budget residuals during selected floods in the Omaha, N ebr., to N ebraska City, N ebr., reach during 1968-76, indicate a consistent shift in sediment transport dynamics from a negative residual condition to a positive residual condition near the flood peak or on the recession side of the peaks. The periods of large positive budget residuals on the flood recession may correspond to periods of sediment storage on the floodplain or in the channel.

The M issouri River has substantially less bedload transport data available than suspended-sediment data, and the data that do exist represent sporadic and discrete measurements or theoretical estimates at main-stem stations, limiting the potential for incorporating bedload into sediment budgets. A vailable bedload data were incorporated into long-term reach budgets for the N ebraska City, N ebr., to St. J oseph, M 0.; St. J oseph, M o., to K ansas City, M o.; and K ansas City, M o., to Hermann, M o., reaches. B edload data were limited for these selected main-stem stations to those using theoretical bedloadstreamflow ratings.

A $n$ accurate total sediment budget is developed by having concurrent data available for all primary suspended-sediment load and bedload components for a reach of interest throughout a period. Such a complete budget, with concurrent record for suspended-sediment load and bedload components, is unavailable for any reach and period in the Lower M issouri River. The primary data gaps are in bedload data and al so in suspended-sediment gains and losses that include ungaged tributary inputs and sediment storage. B edload data gaps in the $\mathrm{M}$ issouri River Basin are much more prevalent than suspended-sediment data gaps, and the first step in the development of reach bedload budgets would be the establishment of a standardized bedload monitoring program at main-stem stations.

Data uncertainties associated with the development of a sediment budget include uncertainties associated with the collection of suspended-sediment and bedload data and the computation of suspended-sediment loads. These uncertainties vary depending on the frequency of data collection, variability of conditions being represented by the discrete samples, and statistical approach to SSL computations. The intensity and longevity of sediment sampling at the M issouri River mainstem stations are greater than at tributary stations, resulting in greater uncertainty in sediment transport at most tributary stations. The average (geometric mean) coefficients of variation of annual SSL $S$ of M issouri River tributary stations for 1968-2014 were greater, 75.0 percent, compared to the mainstem stations, 47.1 percent. The lower coefficient of variation at main-stem stations compared to tributaries, primarily is the result of the lower variability in streamflow and sediment discharge identified at main-stem stations. To obtain similar accuracy between suspended-sediment loads at main-stem and tributary stations, a longer period of record is required of the tributary stations. During, 1968-2014, how ever, the average M issouri River main-stem station record was much more complete (average 87 percent) than the tributary station record (average 28 percent). Suspended-sediment loads in tributaries upstream from the M issouri River at Hermann, M 0., station, account for 84 percent of the 1968-2014 average suspendedsediment load for the M issouri River at Hermann, M 0., station; however, only about 20 percent of suspended-sediment concentration samples collected in 2014 at the M issouri River Basin stations used in this study were collected at tributary stations.

Surrogate methods for the characterization of sediments, including suspended sediments and bedload, can be used to provide real-time continuous measurements, lower monitoring costs, provide greater safety in sampling, and provide a more accurate means of determining sediment transport in rivers and streams. The use of continuous bulk optical properties of water (turbidity) is the most commonly used surrogate for suspended-sediment concentrations. A difficulty in applying surrogate bedload methods for the L ower M issouri River is the inability to calibrate the surrogate technologies to "true" measurements because of the limitations in the traditional and theoretical techniques. A sonar (bathymetric differencing) technique has been the surrogate technique most applied to date (2016) in the L ower M issouri River. The U.S. A rmy Corps of Engineers and U.S. Geological Survey have collected time-lapsed, bed-form data using a multibeam echo sounder at multiple M issouri River locations for the purposes of developing surrogate methods for determining bedload transport in the M issouri River. 


\section{References Cited}

A braham, D.D., 2009, A new method for the measurement of bedload transport using time sequenced bathymetric data: University of I owa, lowa City, lowa, unpublished PhD Dissertation, $72 \mathrm{p}$.

A braham, D.D., Kuhnle, R.A ., and Odgaard, A .J ., 2011, Validation of bed-load transport measurements with timesequenced bathymetric data: Journal of Hydraulic Engineering, v. 137, no. 7, p. 723-728.

A braham, D.D., M cA I pin, T.O., M ay, D.P., Pratt, T.C., and Shelley, J., 2015, U pdate on ISSD 0T V2 method for measuring bed-load transport with time sequenced bathymetric data- Proceedings of the $3 \mathrm{~d}$ J oint F ederal Interagency Conference on Sedimentation and Hydrologic M odeling, Reno, Nev., A pril 19-23, 2015, p. 606-615.

A braham, D.D., and Pratt, T.C., 2010, M issouri River bed-load computations at Kansas City and Washington: U.S. Army Corps of Engineers Research and Development Center, ERDC/CHL Data Report, 25 p.

A braham, D.D., Pratt, T.C., and Sharp, J.A ., 2010, M easuring bedload transport on the M issouri River using time sequenced bathymetric data: 2nd Joint Federal Interagency Conference, Las Vegas, Nev., June 27-July 1, 2010.

A grawal, Y.C., W hitmire, A.L., M ikkelsen, O.A ., and Pottsmith, H.C., 2008, Light scattering by random shaped particles and consequences on measuring suspended sediments by laser diffraction: Journal of Geophysical Research, v. $113,11 \mathrm{p}$.

A lexander, J.S., J acobson, R.B ., and Rus, D.L., 2013, Sediment transport and deposition in the L ower M issouri River during the 2011 flood: U.S. Geological Survey Professional Paper 1798-F, 27 p., accessed M arch 14, 2016, at http:// dx.doi.org/10.3133/pp1798F.

Benedict, P.C., Nelson, M.E., 1944, Comparative field tests on suspended-sediment samplers-Progress Report: Federal Interagency Sediment Project, Report C, 58 p, accessed A pril 28, 2016, at http://water.usgs.gov/fisp/docs/Report_C. pdf.

Biedenharn, D.S., Soileau, S., H ubbard, L.C., H offman, P.H., Thorne, C.R., Bromley, C.C., and Watson, C.C., 2001, $M$ issouri River-Fort Peck Dam to Ponca State Park geomorphological assessment related to bank stabilization: U.S. A rmy Corps of Engineers, O maha District, Engineer Research Development Center, Coastal and Hydraulics L aboratory, 136 p., accessed M ay 4, 2016, at http://digitalcommons.unl.edu/cgi/view content.cgi ?article $=1073 \&$ context =usarmyceomaha.
Chief of Engineers, 1935, L etter from Secretary of War, 73rd Congress, 2nd session, House Document No. 238: United States Government Printing Office, Washington, D.C., $1,245 p$.

Colby, B.R., 1956, Relationship of sediment discharge to streamflow: U.S. Geological Survey Open-File Report 56-27, $170 \mathrm{p}$.

Colby, B.R., and Hembree, C.H., 1955, Computations of total sediment discharge Niobrara River near Cody, Nebraska: U.S. Geological Survey Water-Supply Paper 1357, 187 p.

Dardeau E.A. J r., and Causey E.M ., 1990, D ownward trend in Mississippi River suspended-sediment loads: U.S. Army Engineer Waterways Experiment Station Potamology Program (P-1) Report 5, 67 p., with appendixes.

Davis, B .E., 2005, A guide to the proper selection and use of federally approved sediment and water-quality samplers: U.S. Geological Survey Open-File Report 2005-1087, 20 p.

Diplas, P., Kunnle, R.A., Gray, J.R., Glysson, G.D., and Edwards, T.K., 2008, Sediment transport measurements, in Garcia, M arcelo, ed., Sedimentation engineering - Processes, measurements, modeling, and practice: American Society of Civil Engineers M anuals and Reports on Engineering Practice, Report 110, chap. 5, p. 307-353.

Edwards, T.K., and Glysson, G.D., 1999, Field methods for measurement of fluvial sediment: Techniques of WaterResources Investigations of the U.S. Geological Survey, book 3, chap. C2, $89 \mathrm{p}$.

Einstein, H.A., 1950, The bed-load function for sediment transportation in open channel flows: U.S. Department of A griculture Soil Conservation Service, Technical Bulletin No. 1026, 71 p.

Elliot, C.M., and Jacobson, R.B., 2006, Geomorphic classification and assessment of channel dynamics in the $\mathrm{M}$ issouri National Recreational River, South Dakota and Nebraska: U.S. Geological Survey, Scientific Investigations Report 2006-5313, 66 p.

ENTRIX, Inc., 2011, Missouri River commercial dredging final environmental impact statement: U.S. Army Corps of Engineers, accessed December 19, 2013, at http://www. nwk.usace.army.mil/M issions/R egulatoryB ranch/M issouriRiverCommercial D redging. aspx.

Esri, 2014, A rcGIS-M apping and analysis for understanding our world, version 10.3: Esri Web site, accessed July 17, 2014, at http://www.esri.com/software/arcgis/. 
Federal Interagency Sedimentation Project, 1940, Field practice and equipment used in sampling suspended sediment-Inter-agency Water R esources Council Subcommittee on Sedimentation, Report No. 1: Hydraulic Laboratory, University of lowa, I owa City, Iowa, 175 p., accessed M ay 4, 2016, at http://water.usgs.gov/fisp/docs/Report_1.pdf.

Ferrell, J., 1996, Soundings- 100 years of the M issouri River navigation project: Omaha, Nebr., U.S. Army Corps of Engineers, $171 \mathrm{p}$.

Gaeuman, D., and J acobson, R.B., 2007, Field assessment of alternative bed-load transport estimators: Journal of Hydraulic Engineering, v. 133, no. 12, p. 1319-1328.

Galloway, J.M ., Rus, D.L., and A lexander, J.S., 2013, Characteristics of sediment transport at selected sites al ong the Missouri River during the high-flow conditions of 2011: U.S. Geological Survey Scientific Investigations Report 2013-5006, $31 \mathrm{p}$.

Gray, J.R., and Gartner, J.W., 2009, Technological advances in suspended-sediment surrogate monitoring: Water Resources Research, v. 45, 20 p.

Gray, J.R., Laronne, J.B., M arr, J.D.G., 2010, B edload-surrogate monitoring technologies: U.S. Geological Survey Scientific Investigations Report 2010-5091, 37 p. [Also available at http://pubs.usgs.gov/sir/2010/5091.]

Gomez, Basil, 2006, The potential rate of bed-load transport: Proceedings of the National A cademy of Sciences, v. 103, no. 46, p. $17,170-17,173$.

Guy, H.P., 1969, Laboratory theory and methods for sediment analysis: Techniques of Water-Resources Investigations of the U.S. Geological Survey, book 5, chap. C 1, 58 p.

Heath, R.E., B rown, G.L., Little, C.D., Pratt, T.C., Ratcliff, J.J ., A braham, D.D., Perkey, D., Ganesh, N.B., M artin, K., and M ay, D.P., 2015, Old River control complex sedimentation investigation: U.S. Army Corps of Engineers Coastal and Hydraulics L aboratory, ERDC/CHL TR-15-8, $128 \mathrm{p}$.

Heimann, D.C., M orris, D.M ., and Gemeinhardt, T.R., 2015, $N$ utrient contributions from alluvial soils associated with the restoration of shallow water habitat in the L ower M issouri River: River Research and Applications, v. 31, no. 3, p. 323-334.

Heimann, D.C., Rasmussen, P.P., Cline, T.L., Pigue, L.M ., and Wagner, H.R., 2010, Characteristics of sediment data and annual suspended-sediment loads and yields for selected lower M issouri River mainstem and tributary stations, 1976-2008. U.S. Geological Survey Data Series Report 530, 58 p., accessed M ay 4, 2016, at http://pubs.usgs.gov/ $\mathrm{ds} / 530 /$.
Heimann, D.C., Sprague, L .A ., and Blevins, D.W., 2011, Trends in suspended-sediment loads and concentrations in the Mississippi River Basin, 1950-2009: U.S. Geological Survey Scientific Investigations Report 2011-5200, 33 p.

Hilldale, R.C., Carpenter, W.O., Goodwiller, B., Chambers, J.P., and Randle, T.J ., 2014, Calibration of bed load impact sensors for surrogate sediment measurement: Bureau of Reclamation, Research and Development Office, Science and Technology Program Close-O ut R eport SRH-2014-32, $38 \mathrm{p}$.

Holmes, R.R. J r., 1996, Sediment transport in the lower M issouri and the central M ississippi Rivers, June 26 through September 14, 1993: U.S. Geological Survey Circular 1120-I, 23 p.

Horowitz, A.J ., 2003, A n evaluation of sediment rating curves for estimating suspended sediment concentrations for subsequent flux calculations: Hydrological Processes, v. 17, p. 3387-3409.

Hubbart, J .A ., 2012, U sing sediment particle size class analysis to better understand urban land-use effects: International J ournal of A pplied Science and Technology, v. 2, no. 1, p. 12-27.

Hubbell, D.W., 1964, A pparatus and techniques for measuring bedload: U.S. Geological Survey Water-Supply Paper 1748, 74 p., accessed A pril 15, 2015, at http://pubs.er.usgs.gov/ publication/wsp1748.

Jacobson, R.B., B levins, D.W., and Bitner, C.J ., 2009, Sediment regime constraints on river restoration-An example from the lower M issouri River, in J ames, L.A ., Rathburn, S.L., and W hittecar, G.R., eds., M anagement and restoration of fluvial systems with broad historical changes and human impacts: Geological Society of America Special Paper 451, p. 1-22

Jordan, P.R., 1965, Fluvial sediment of the Mississippi River at St. Louis, Missouri: U.S. Geological Survey Water-Supply Paper 1802, $89 \mathrm{p}$.

Keown, M .P.; Dardeau E.A., Jr.; Causey E.M ., 1986, Historic trends in the sediment flow regime of the Mississippi River: Water Resources Research, v. 22, no. 11, p. 1555-1564.

K oltun, G . F., Eberle, M ichael, Gray, J.R., and Glysson, G.D., 2006, U ser's manual for the Graphical Constituent L oading Analysis System (GCLAS): U.S. Geological Survey Techniques and $M$ ethods, book 4, chap. C1, 51 p. [A Iso available at http://pubs.er.usgs.gov/usgspubs/tm/tm4C1.]

K oltun, G.F., Gray, J.R., and M CEIhone, T.J ., 1994, U ser's $M$ anual for SEDCA LC, a computer program for computation of suspended-sediment discharge: U.S. Geological Survey O pen-File Report 94-459, $46 \mathrm{p}$. 
K rahulik, J.R., Densmore, B.K ., A nderson, K .J ., and K avan, C.L., 2015, Hydrographic surveys at seven chutes and three backwaters on the M issouri River in N ebraska, lowa, and Missouri, 2011-13: U.S. Geological Survey Data Series 909, 28 p., accessed February 23, 2016, at http://dx.doi. org/10.3133/ds909.

L ewis, J., 1996, Turbidity-controlled suspended sediment sampling for runoff event load estimation: Water Resources Research, v. 32, no. 7, p. 2299-2310.

M ahmood, K ., 1981, M issouri River bedload evaluation through multi-channel sequential profiles: U.S. Army Corps of Engineers, M issouri River Division, M RD sediment series no. 23, $55 \mathrm{p}$.

M arineau, M .D., Gendaszek, A .S., M agirl, C.S., Czuba, C.R., and Czuba, J.A ., 2012, Surrogate bedload monitoring using hydrophones in the gravel-bedded Cedar River, Washington, in Hydraulic $M$ easurements and Experimental $M$ ethods Conference, Snowbird, U tah, A ugust 12-15, 2012, Proceedings, $6 \mathrm{p}$.

M cElroy, B ., and M ohrig, D., 2009, Nature of deformation of sandy bed forms: Journal of Geophysical Research, v. 114, no. 3, 13 p., accessed M ay 4, 2016, at http://onlinelibrary. wiley.com/doi/10.1029/2008j F001220/full.

M eade, R.H., 1995, Setting-Geology, hydrology, sediments, and engineering of the M ississippi River, in M eade, R.H., ed., Contaminants in the Mississippi River, 1987-92: U.S. Geological Survey Circular 1133, p. 13-30.

M eade, R.H., and M oody, J.A ., 2010, Causes for the decline of suspended-sediment discharge in the M ississippi River system, 1940-2007: Hydrological Processes, v. 24, p. 35-49.

M edalie, L aura, Chalmers, A.T., Kiah, R.G., and Copans, Benjamin., 2014, Use of acoustic backscatter to estimate continuous suspended sediment and phosphorus concentrations in the Barton River, Northern Vermont, 2010-2013: U.S. G eological Survey O pen-File Report 2014-1184, 29 p, with appendixes, accessed M ay 4, 2016, at http://pubs.usgs. gov/of/2014/1184/.

$\mathrm{N}$ ania, J.F., 2015, Studying surrogates to estimate suspended sediment concentrations on the M issouri River at N ebraska City, Nebraska, in joint 10th Federal Interagency Sedimentation Conference, 5th Federal Interagency Hydrologic Modeling Conference, Reno, Nev., April 19-23, 2015: Sedimentation and Hydrology, accessed J une 6, 2015, at http://www.sedhyd.org/2015/openconf/modules/request. php? module $=$ oc_program\&action $=$ summary.php $\& \mathrm{id}=139$.

National Research Council, 2011, M issouri River planningRecognizing and incorporating sediment management: Washington, D.C., The N ational A cademies Press, 152 p.
Nittrouer, J .A ., Allison, M .A ., and Campanella R ., 2008, B edform transport rates for the lowermost Mississippi River: J ournal of Geophysical Research, Earth Surface, v. 113, no. F3, 113 p., accessed M arch 22, 2016, at http://onlinelibrary. wiley.com/doi/10.1029/2007J F 000795/full.

Nordin, C.F., Jr., and Meade, R.H., 1981, The flux of organic carbon to the oceans-Some hydrologic considerations in Carbon Dioxide effects, research and assessment program, flux of organic carbon by rivers to the oceans: Woods Hole, Mass., U.S. Department of Energy, Office of Energy Research, p. 173-218.

Ohlmacher, G.C., 1998, Fluvial hydraulics and sediment transport, chap. 3 in The K ansas River corridor-Its geologic setting, land use, economic geology, and hydrology: Kansas Geological Survey, K ansas River Corridor Study, accessed October 22, 2014, at http://www.kgs.ku.edu/Publications/ $\mathrm{KR} / \mathrm{kr}$ hydro.html.

Parker, R.S., 1988, Uncertainties in defining the suspended sediment budget for large drainage basins, in Sediment Budgets-Proceedings of the Porto A legre Symposium, Porto Alegre, Brazil, December 1988: Porto Alegre, Brazil, IA HS Publication no. 174, p. 523-532.

Perkey, D., Pratt, T., Ganesh, N ., 2010, Comparison of SSC measurements with acoustic backscatter data-West B ay sediment diversion, M ississippi River, in 2d J oint Federal Interagency Conference, Las Vegas, Nev., June 27-July 1, 2010, Proceedings, $12 \mathrm{p}$.

Pokrefke, T.J ., A braham, D .A ., H offman, P.H ., Thomas, W.A., Darby, S.E., Thorne, C.R., 1998, Cumulative erosion impacts analysis for the $M$ issouri River $M$ aster Water Control Manual review and update study: U.S. Army Corps of Engineers, Waterways Experiment Station, Technical Report CHL-98- 7, 288 p.

Porterfield, G., 1972, Computation of fluvial-sediment discharge: Techniques of Water-Resources Investigations of the U.S. Geological Survey, book 3, chap. C3, 66 p.

Putnam, J .E., and Pope, L.M ., 2003, Trends in suspendedsediment concentration at selected stream sites in $\mathrm{K}$ ansas, 1970-2002: U.S. Geological Survey Water-Resources Investigations Report 03-4150, 36 p., accessed M arch 22, 2016, at http://ks.water.usgs.gov/Kansas/pubs/reports/ wrir.03-4150.html.

Rasmussen, P.P., Gray, J.R., Glysson, G.D., and Ziegler, A.C., 2009, Guidelines and procedures for computing time-series suspended-sediment concentrations and loads from instream turbidity-sensor and streamflow data: U.S. Geological Survey Techniques and M ethods, book 3, chap. C4, $52 \mathrm{p}$. 
Runkel, R.L., Crawford, C.G., and Cohn, T.A., 2004, L oad Estimator (LOADEST)-A FORTRAN program for estimating constituent loads in streams and rivers: U.S. Geological Survey Techniques and M ethods, book 4, chap. A 5, 69 p.

Rus, D.L., Galloway, J.M ., and A lexander, J.S., 2015, Characteristics of sediment transport at selected sites al ong the Missouri River, 2011-12: U.S. Geological Survey Scientific Investigations Report 2015-5127, 34 p., accessed M ay 4, 2016, at https://pubs.er.usgs.gov/publication/sir20155127.

Schalk, G.K., Holmes, R.R., and J ohnson, G.P., 1998, Physical and chemical data on sediments deposited in the M issouri and Mississippi River flood plains during the July through August 1993 flood: U.S. Geological Survey Circular $1120-L, 62 p$.

Shelley, J., A braham, D.D, and M cA Ipin, T.0., 2013, Removing systemic bias in bed-load transport measurements in large sand-bed rivers: Journal of Hydraulic Engineering v. 139, no. 10, p. 1107-1111.

Smith, C., and Croke, B ., 2005, Sources of uncertainty in estimating suspended sediment load, in Sediment Budgets 2-Proceedings of the Seventh IAHS Scientific Assembly, Foz do Iguaçu, Brazil, April 2005: Foz do Iguaçu, Brazil, IA HS Publication 292, p. 136-143,.

Topping, D., M elis, T., Rubin, D., and Wright, S.A., 2004, High-resolution monitoring of suspended-sediment concentration and grain size in the Colorado River using laser-diffraction instruments and a three-frequency acoustic system, in Liu, Cheng, ed., 9th International Symposium on River Sedimentation, Y ichang, China, October 18-21, 2004, Proceedings: Beijing, China, Tsinghua University Press, p. 2507-2514.

Topping, D.J ., W right, S.A., M elis, T.S., and Rubin, D.M ., 2006, High-resolution monitoring of suspended-sediment concentration and grain size in the Colorado River using laser-diffraction instruments and a three-frequency acoustic system-Proceedings of the 8th Federal Interagency Sedimentation Conference, R eno, Nev., A pril 2-6, 2006, CD-ROM , ISBN 0-9779007-1-1, p. 539-546.

Turnipseed, D.P., and Sauer, V.B., 2010, Discharge measurements at gaging stations: U.S. Geological Survey Techniques and $M$ ethods, book 3, chap. A 8, 87 p.

U.S. A rmy Corps of Engineers, 1951, Suspended Sediment in the M issouri River-Daily Record or Water Y ears 19371948: Omaha, Nebraska, U.S. Army Corps of Engineers, M issouri River Division, $219 \mathrm{p}$.

U.S. A rmy Corps of Engineers, 1957, Suspended Sediment in the M issouri River-Daily Record for Water Years 19491954: Omaha, Nebraska, U.S. Army Corps of Engineers, M issouri River Division, $210 \mathrm{p}$.
U.S. A rmy Corps of Engineers, 1965, Suspended Sediment in the M issouri River-Daily R ecord for Water Y ears 19551959: Omaha, Nebraska, U.S. Army Corps of Engineers, M issouri River Division, 118 p.

U.S. A rmy Corps of Engineers, 1970, Suspended Sediment in the M issouri River-Daily R ecord for Water Y ears 19601964: Omaha, Nebraska, U.S. Army Corps of Engineers, M issouri River Division, $190 \mathrm{p}$.

U.S. A rmy Corps of Engineers, 1972, Suspended Sediment in the M issouri River-Daily R ecord for Water Y ears 19651969: Omaha, Nebraska, U.S. Army Corps of Engineers, M issouri River Division, 248 p.

U.S. A rmy Corps of Engineers, 1976, Suspended Sediment in the M issouri River-Daily Record for Water Y ears 1970-1974: Kansas City, Missouri, U.S. Army Corps of Engineers, Missouri River Division, 201 p.

U.S. A rmy Corps of Engineers, 2009, M issouri River bed degradation reconnaissance study: U.S. Army Corps of Engineers K ansas City District, 67 p., accessed M ay 4, 2016, at http://www.nwk.usace.army.mil/Portals/29/docs/civilworks/ M O riverbeddegradation/M O R iverB edD egradationReconStudy.pdf.

U.S. A rmy Corps of Engineers, 2012, M issouri River stage trends: Missouri River Basin Water Management Division, Omaha, N ebraska, $18 \mathrm{p}$.

U.S. A rmy Corps of Engineers, 2015, M issouri River Recovery Program, Shallow Water Habitat, accessed M ay 4, 2016, at http://moriverrecovery.usace. $\operatorname{army} . \mathrm{mil} / \mathrm{mrrp} / \mathrm{f}$ ? $\mathrm{p}=136: 1: 0$.

U.S. Department of A griculture, 2009, Phase II Sedimentation Assessment for the Upper Missouri River Basin: U.S. Department of A griculture $\mathrm{N}$ atural Resources Conservation Service A ssessment Report, $51 \mathrm{p}$.

Voichick, N., and Topping, D.J, 2014, Extending the turbidity record $-M$ aking additional use of continuous data from turbidity, acoustic-Doppler, and laser diffraction instruments and suspended-sediment samples in the Colorado River in Grand Canyon: U.S. Geological Survey Scientific Investigations Report 2014-5097, 31 p., accessed M ay 4, 2016, at http://dx.doi.org/10.3133/sir20145097.

Wall, G.R., Nystrom, E.A ., and Litten, S., 2006, U se of an $A D C P$ to compute suspended-sediment discharge in the tidal Hudson River, New York: U.S. Geological Survey Scientific Investigations Report 2006-5055, 16 p.

Walling, D.E., 1977, A ssessing the accuracy of suspended sediment rating curves for a small basin: Water Resources Research, v. 13, no. 3, p. 531-538. 
Watson, C.C, and Biedenharn, D.S., 2009, Specific gage analysis of stage trends on the middle Mississippi River: Vicksburg, Miss., Biedenharn Group, LLC, report submitted to the U.S. A rmy Corps of Engineers, St. Louis District, $32 \mathrm{p}$.

WEST Consultants, Inc., 1999, M issouri River levee unit L385 sediment analysis: Bellevue, Wash., report submitted to the U.S. A rmy Corps of Engineers, K ansas City District, $63 \mathrm{p}$.

Wolman, M.G., and Leopold, L.B., 1957, River flood plainsSome observations on their formation: U.S. Geological Survey Professional Paper 282-C, 109 p.
Wood, M.S., 2010, Evaluation of sediment surrogates in rivers draining to lower granite reservoir, ID and WA: Las Vegas, Nev., J une 27-J uly 1, 2010-A bstract submitted to 2nd J oint Federal Interagency Conference, $12 \mathrm{p}$.

Wood, M.S., 2014, Estimating suspended sediment in rivers using acoustic Doppler meters: U.S. Geological Survey Fact Sheet 2014-3038, 4 p., accessed M ay 4, 2016, at http:// dx.doi.org/10.3133/fs20143038.

Wood, M.S., and Teasdale, G.N., 2013, U se of surrogate technologies to estimate suspended sediment in the Clearwater River, Idaho, and Snake River, Washington, 2008-10: U.S. Geological Survey Scientific Investigations Report 2013-5052, 30 p. 


\section{Tables 1-9}

Tables 1-9 are available for download as Excel files at http://dx.doi.org/10.3133/sir20165097.

Table 1. Summary of sediment data availability and station characteristics of sediment monitoring stations used in study.

Table 2. Annual suspended-sediment loads and flow-weighted concentrations for selected stations in the Lower Missouri and Mississippi River Basins, 1930-2014.

Table 3. Daily suspended-sediment loads for selected stations in the Lower Missouri and Mississippi River Basins, 1939-2014.

Table 4. Summary of bedload measurements and computations available for selected stations on the Lower Missouri and Mississippi Rivers, 1950-2014.

Table 5. Missouri River commercial dredging mass by year and river reach, 1968-2014.

Table 6. Estimated Missouri River Recovery Program sediment additions by year and by reach, 1993-2014

Table 7. Selected annual bed mass changes by reach, Lower Missouri River, 2007-14.

Table 8. Long-term, average sediment budget for the Lower Missouri River, by reach, post-impoundment period, 1968-2014.

Table 9. Annual, monthly, and daily sediment budget for the Lower Missouri River, reach 3, Omaha, Nebraska, to Nebraska City, Nebraska, 1968-2014.

\section{Publishing support provided by:}

Rolla Publishing Service Center

For more information concerning this publication, contact:

Director, USGS Missouri Water Science Center

1400 Independence Road

Rolla, M0 65401

(573) 308-3667

Or visit the Missouri Water Science Center Web site at:

http://mo.water.usgs.gov/ 




\section{$\frac{\mathbb{2}}{3}$}

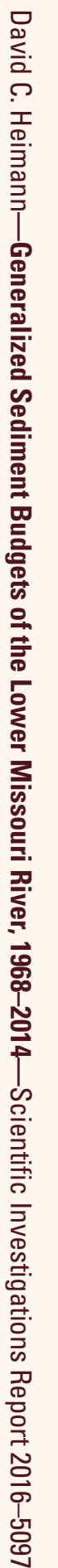

